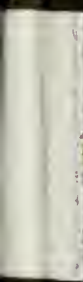




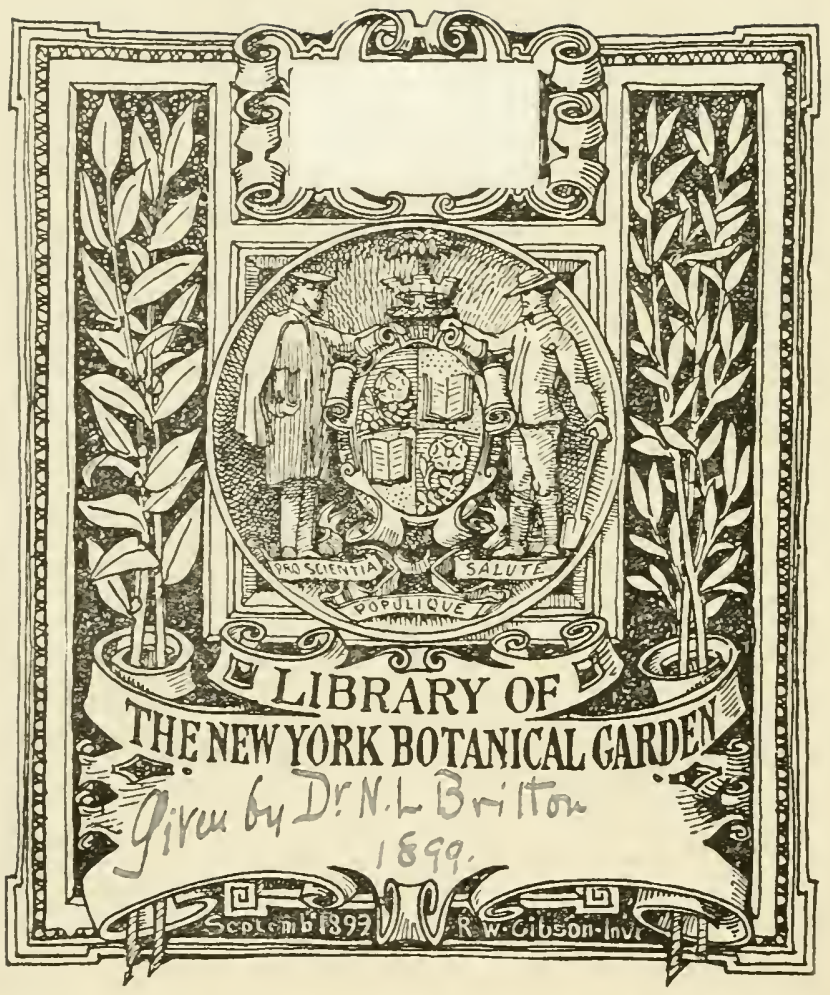




(So. Dak. Bul. No. 64.)

April, 1899.

Bulletin 64.

\section{U. S.}

\section{EXPERIMENT STATION SOUTH DAKOTA.}

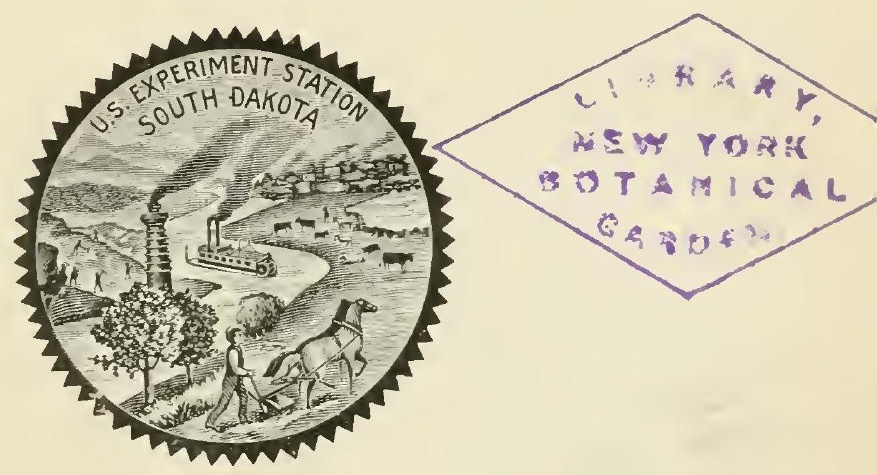

IN CONNECTION WITH THE

SOUTH DAKOTA AGRICULTURAL COLLEGE.

\section{FERNS AND FLOWERING PLANTS OF SOUTH DAKOTA.}

DEPARTMENT OF BOTANY AND ENTOMOLOGY.

BROOKINGS, SOUTH DAKOTA.

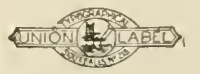

- IOUX FALLS, S. D.

WILL A. BEACH, PRINTER AND BINDER.
I 899. 
REGENTS OF EDUCATION.

Hon. H. H. Blarr, Pres ................ Elk Point

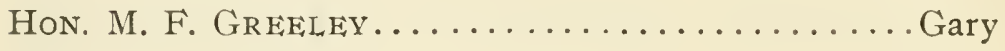

Hon. R. W. HAIre, Sec'y ................ A berdeen

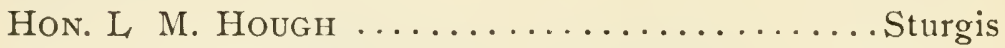

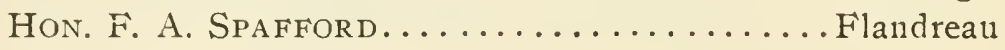

\section{STATION COUNCIL.}

Dr. F. A. SpafFord, Regent Member.

Jno. W. Heston, President of College.

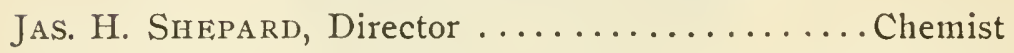
E. C. Chilcot't, Vice Director ............... Agriculturist D. A. Saunders............ Botanist and Entomologist E. L. MoOre. . . . . . . . . . . . . . . . Zoologist N. E. HANSEN . . . . . . . . . . . . Horticulturist E. A. BurneTTT.................. Animal Husbandry A. M. Allen, Secretary and Accountant.

ASSISTANTS.

A. B. Hol $\ldots \ldots \ldots \ldots \ldots \ldots \ldots \ldots \ldots$. . . . . . . . . . . . . . . . . . . . .

. W. H. Knox........................ Chemistry

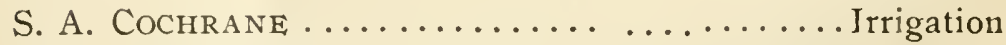

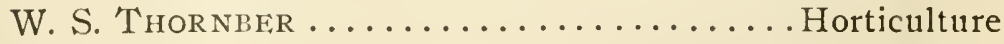

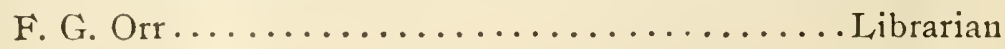

Any farmer of the state can have the Bulletins of this Station free upon application to the Director. 


\section{FERNS AND FLOWERING PLANTS OF SOUTH DAKOTA.}

\section{DEPARTMENT OF BOTANY AND ENTOMOLOGY.}

\section{A. Saunders.}

\section{INTRODUCTION.}

The results embodied in the accompanying catalogue are based on specimens in the College herberium, and on notes taken in the field by Professor T. A. Williams and the writer.

The nomenclature followed is the modification of the Paris Code adopted by the Botanical Club of the American Association for the Advancement of Science at Rochester in 1892 and amended at the Madison, Wis., meeting in 1893 . The only synonyms given are such as would be a help to one accustomed to using Gray's Manual.

In preparing this catalogue, Dr. P. A. Rydberg's Flora of the Black Hills* has been freely used. Specimens have also been received from various collectors in that region. Professor Williams has made extensive collections in the Sioux valley, has done considerable work along Bigstone Lake, and has made one trip from Pierre to Rapid City and return, obtaining many interesting specimens, especially from the Bad Lands. Messrs. David Griffiths, Earl Douglass, Jno. J. Thornber, students of Professor Williams, have done considerable collecting east of the Missouri river. Mr. L. W. Carter has made various collecting trips in the eastern part of the state, and, in company with Mr. Griffiths, one extended trip from Forest City along the Moreau river to the Black Hills, returning along the Cheyenne river to Fort Pierre. The 
writer has collected over most of the state east of the Missouri river, and, in company with Mr. J. R. Towne, in the summer of 1897 made very careful examinations of the Little Minnesota river and its tributaries. On this trip many eastern species heretofore unknown to the state were obtained.

Acknowledgment is due Dr. N. L. Britton, Dr. P. A. Rydberg, and Messrs. Nash and Bicknell of the New York Botanical Garden, Dr. L. H. Bailey of Cornell University, and Professor Sargent of the Arnold Arboretum for the verification and determination of certain species. 


\section{CATALOGUE.}

PTERIDOPHY'TES. - THE FERNS AND THEIR
ALLIES.

OpHIOGLOSSACE出.-The Adder-Tongue Family.

Botrychium matricarifolium, A., Br., Matricary Grapefern.

Two specimens doubtfully referred to this species were collectea near Custer, in the Black Hills, by Dr. Rydburg.

Botrychium virginianum, (L.) Sw. Virginian Grapefern.

In wooded ravines in the Minnesota region and in the Black Hills; rare.

Polypodiace瓜, 一 The True Ferns.

Onoclea sensibilis, L., Sensitive fern.

Near Rapid City, in the Black Hills.

Onoclea struthiopteris, (L.) Hoffm. Ostrich-fern.

Along shaded streams in the Minnesota Valley and the Black Hills.

Woodsia scopulina, D. C. Eaton. Rocky Mountain Woodsia.

On wooded hillsides in the Black Hills; rare.

Woodsia Oregon, D. C. Eaton. Oregon Woodsia.

Common throughout the Black Hills.

Cystopteris fragilis, (L.) Bernh. Brittle-fern.

On damp shady banks bordering streams and lakes throughout the state.

Phegopteris dryopteris, (L.) Fee. Oak-fern.

In deep woods in the Black Hills. 
Dryopteris Felix-Mas, (L.) Schott. Male-ferw.

Anowg rocks in the Black Hills.

Asplenim trichomanes, L. Maiden-hair spleanwort. Crevices of rocks in the Black Hills.

Asplenium Felix-foemina, (L.) Fee. Bernl. Ladyfern.

In the Black Hills.

Asplenimu Septentrionale, (L.) Hoffm. Northern spleanwort.

In crevices of rocks in the Black Hills.

Adiantum Capillus-Veneris, L. Venus-hair fern.

Along a warm stream, near Cascade, in the Black Hills. *

Pteris aquilina, L. Brake.

Near Custer, in the Black Hills.

Pellaca atropurpurea, (L.) Link. Purple-stemed Cliffbrake.

Common in crevices of rocks in the Black Hills.

Pellaca Breweri, Eaton. Brewer's Cliff-Brake.

In limestone crevices near Bull Spring, in the Black Hills.

Cheilanthes gracilis, (Fee.) Mett. Slender Lip-fern.

On exposed rocks in the Black Hills.

Polypodium vulgare, L. Common Polypody.

In crevices of rocks in the Black Hills.

Polypodium vulgare rotundatum, Wilde. Roundlobed Polypody.

In crevices of rocks near Custer, in the Black Hills.

MarSileace..-Marsilea Family.

Marilea vestita, Hook \& Grev. Hairy Marsilea.

Very abundant in swails and ditches from the James river valley westward to the Black Hills. 
EQUISETACE.⿱一𫝀. - Horse-Tail Family.

Equisetum arvense, L. Field Horsetail.

In low sandy soil in the Minnesota and Sionx valleys, and in the Black Hills.

Equisetum sylvaticum, L. Wood Horsetail.

In moist woods in the Black Hills.

Equisetum fluviatile, L. Swamp Horsetail.

In swamps in the Minnesota region.

Equisetum robustum, A., Br. Stout Scouring-rush.

In wet places throughout the state; less common than the next.

Equisetum laevigatum, A., Br. Smooth Scouringrush.

In low wet places; very abundant throughout the state.

LyCOPODIACE, 无. Club Moss Family.

Lyeopodium obscurum, L. Ground Pine.

In moist woods in the Black Hills.

Selaginelilace无, 一The Little Club Mosses.

Selaginella rupestris, (L.) Spring. Rock Selaginella. On rocky slopes in the Black Hills.

SPERMIOPHY'TES. -SEED BEARING PLAN'TS.

GYMNOSPERM F.-GYMNOSPERMS.

PINACE正.

Pinus ponderosa scopulorum, Englm. Western Yellow pine.

Throughout the Black Hills.

Picea Canadensis, (Mill.) B. S. P. White Spruce.

In the Black Hills, especially in the northern part. 
Juniperus nana, Willd. Juniper.

Juniperus Sibericus. Burgsd.

On dry knolls in the Black Hills.

Juniperus Virginiana. Red Cedar.

Rare in the Black Hills proper, common in the foothills and in the vicinity of streams from the Black Hills eastward to the Missouri river. It is found occasionally on the bluffs on the east side of the river.

Juniperus Sabina prostrata, (Pers.) Loud. Creeping Red Cedar.

On dry foothills in the Black Hills.

ANGIOSPERM无-THE TRUE FLOWERING PLAN'TS.

MONOCOTYLEDONES._MONOCO'TYLEDONS.

Typhace死.-Cat-Tail Family.

Typha latifolia, L. Broad leaved Cat-tail.

In marshes throughout the state.

Sparganiace, i. - The Burreed Family.

Sparganimm eurcarpum, Englm. Broad fruited Burreed.

In swamps, marshes and along streams throughout the state.

NAIADACE. The Naiad Family.

Potamogeton lonchite., Tnckerm. Long-leaved Pondweed.

In ponds and slow streams throught the state.

Potamogeton amplifolius, Tuckerm. Large-leaved Pond weed.

In ponds and slow streams throughout the state. 
Potamogeton heterophyllus, Schreb. Various-leaved Pondweed.

In ponds and lakes from the Missouri river eastward.

Potamogeton perfoliatus Richardsonii, A. Bennet. Clasping-leaved Potamogeton.

Common in the Minnesota and Sioux Valleys.

Potamogeton alpinus, Balbis. Northern Pondweed.

In the Sioux river near Brookings.

Potamogeton foliosus, Raf. Leafy Pondweed.

In ponds and streams throughout the state.

Potamogeton foliosus niagarensis,(Tuckerm.) Morong.

In the Sioux Valley.

Potamogeton zosteraefolius, Sclum. Ell-grass Pondweed.

In the Sioux and James valleys.

Potamogeton Hillii, Morong. Hill's Pondweed.

In the Sioux valley.

Potamogeton pusillus, L. Small Pondweed.

Common in ponds from the Missouri valley eastward.

Potamogeton pectinatus, L. Fennel-leaved Pondweed.

In lakes and streams throughout the state.

Potanogreton marinus occidentalis, Robbins. The Westeru Pondweed.

In the Black Hills.

Potamogaton palustris, L. Swamp Patamogeton.

In shallow water in the Sioux Valley.

Zauirhollia palustris, L. Zanichellia.

In brackish or fresh water ponds throughout the state.

Ruplia ocricleutalis, S. Wat. Western Ruppia.

In a strongly alkaline pond in the Minnesota valley, near Gary.

Naias flexilis, (Willd.) Rost \& Schmidt. Slender Naias. In pounds and lakes throughout the state. 
SCHEUCHZERIACE -Arrow-Grass Family

Triglochin palustris, L. Marse Arrow-grass.

In bogs in the Minnesota Valley.

Triglochin manitima, L. Seaside Arrow-grass.

In marshes throughout the state.

AlismaCe无.-Water-Plantain Fanily.

Alisma plantago-aquatioa, L. Water-plantain.

Common in the edges of lakes and streams throughout the state.

Echinodorus rordifolius, (L。) Griseb. Upright Burhead.

Occasional in the southeastern corner of the state, Sioux Falls; Yankton.

Lophotocarpus calycinus, (Engelmu.) J. G. Suith. Lopotocarpus.

Occasional in swamps from the Missouri river eastward.

Sagittaria arifolia, Nutt. Arum-leaved Arrowhead.

In the Minnesota and James valleys and in the Black Hills.

Sagittaria graminea, Michx. Grass-leaved Sagittaria.

In shallow waters from the Missouri valley eastward.

Sagittaria latifolia, Willd. Broad-leaved Arrowhead.

In shallow water throughout the state.

VAlitisneriace王. Tape-Grass Family.

Philotria Canadensis, (Michx.) Britton. Waterweed, Ditch moss.

Elodea Canadensis, Michx.

In the Minnesota and Sioux river valleys.

Vallisneria spiralis, L. Tape-grass. Ell-grass.

In Big Stone lake, in the Minnesota valley. 
Gramine. E. - Grass Famiiy.

Andropogon Hallii, Hack. Hall's Beardgrass. Turkeyfoot Grass.

In the Bad Lands. Probably more or less abundant from the Missouri valley westward to the Black Hills.

Andropogon s(ooparius, Michx. Brom Beardgrass.

Abundant throughout the state. A valuable forage grass.

Andropogon furcatus, Muhl. Forked Beardgrass.

Abundant from the Missouri eastward.

Chryopogon avenaceus, (Michx.) Benth. Bushy Bluestem, Indian Grass.

In low damp ground from the Missouri valley eastward. Locally abundant.

Syntherisma lincaris, (Krock.) Nash. Small Crab Grass. Fanicum glabrum. Gaud.

Sparingly introduced into the southeastern part of the state. Near Yankton and Sioux Falls.

Syntherisma sanguinalis, (L.) Nash. Finger Grass;

Large Crab Grass.

Panicum sanguinale, L.

Introduced into yards from the Missouri valley eastward.

Panicum C'rus-galli, L. Barnyard Grass.

Abundant in waste places throughout the state.

Panicum Ścribnelianum, Nash. Scribner's Panicum.

Abundant on prairies in the Minnesota and Sioux valleys.

Panicum Wilcoxiamum, Vasey. Wilcox's Panicum.

On prairies in the Minnesota valley; rare.

Panicrun dichotonum, L. Forked Panicum.

In the Minnesota and Sioux valleys.

Panicum visciclum, Ell. Velvety Panicum. 
Panicum Scoparium, Michx.

In the Sioux valley and the Black Hills.

Panicum depauperatum, Muhl. Starved Panicum.

In dry soils in the Sioux and James valleys and in the Black Hills.

Panicum viraatum, L. Tall Smooth Panicum.

In low ground throughout the state.

Panicum Capillare, L. Witch Grass.

A common weed in waste places throughout the state.

Ixophorus glaucus, (L.) Nash. Foxtail. Pigeon grass. Setaria glauca, L.

A miserable weed in cultivated grounds throughout the state.

Ixophorus Viridis, (L.) Nash. Green Foxtail.

Setaria Viridis, L.

Same range as the last.

Ixophorus Italicus, (L.) Nash. Hungarian Grass.

Setaria Italica, R. \& S.

Escaped along roadsides in the Sioux valley.

C'enchrus tribuloides, L. Sand Burr.

In waste and sandy places throughout the state. More abundant westward.

Zizania aquatica, L. Wild Rice. Indian Rice. Water Oats.

In shallow water from the Missouri river eatward.

Homalocencluns virginicus, (Willd.) Britton. White Grass.

Leersia viriginica, R. \& S.

In shallow water in the Minnesota and Sioux valleys.

Homalocenclums oryzoides, (L.) Poll. Rice Cut Grass. Leersia oryzoides, L.

In swampy ground from the Missouri river eastward:

Plualaris arundinacea, L. Reed. Canary Grass.

From the Missouri valley eastward and in the Black Hills. 
Phalaris Camariensis, L. Canary Grass.

A European grass which has escaped in the eastern part of the state.

Savastana odorata, (L.) Scribn. Holy Grass. Seneca Grass. Hierochloe borealis. R. \& S.

From the Missouri valley eastward and in the Black Hills.

Aristicla purpurea, Nutt. Purple Aristida.

From the James valley westward, an abundant grass on the range. It forms large bunches of dry wiry leaves that cattle will not eat or the mower cut.

Stipa Macounii. Macoun's Stipa.

In the Black Hills.

Stipa viudula, Trin. Green Stipa.

Throughout the state.

Stipa avenacea, L. Black-oat Grass.

In the Minnesota region.

Stipa comata, Trin. \& Rupr. Westeru Stipa.

From the Missouri valley westward.

Stipa Spartea, Trin. Porcupine Grass.

In the Minnesota, Sionx, James and Missouri valleys and in the Black Hills.

Oryzopsis micrantha, (Trin. \& Rupr.) Thurb. Small flowered Mountain Rice.

From the Missouri valley westward.

Oryzopsis asperifolia, Michx. White grained Mountain Rice.

In the Black Hills.

Oryzopsis melanocarpa, Muhl. Black-fruited Mountain Rice.

On wooded bluffs in the Minnesota valley.

Oryzopsis cuspidata, (Nutt.) Vasey. Silky Oryzopsis.

Throughout the state. 
Oryzopsis .Junceal, (Michx.) B. S. P. Slender Mountain Rice.

In the Black Hills.

Muhlenberegia Mexicana, (L.) Trin. Meadow Muhlenbergia.

In woods and thickets in the Minnesota, Sioux and James valleys.

Muhlenhergera racemosa, (Michx.) B. S. P.

From the Missouri valley eastward and in the Black Hills.

Muhlenbergia ambigua, Torr. Minnesota Muhlenbergia.

In the Minnesota region.

Mublenbergia Sylvatica, Torr. Wood Muhlenbergia.

In the Minnesota, Sioux and Janes valleys.

Muhleubergia Wrightii, Vasey. Wright's Muhlenbergia.

In the Black Hills.

Brachyelytrum erectum, (Schred.) Beauv. Brachelytrum.

In the Minnesota and Sioux valleys and the Black Hills.

Phlenu pratense, I. Timothy.

Escaped along streams and road sides in the'Minnesota and Sioux valleys.

Alopecurus geniculatus, L. Marsh Fox-tail.

In the Sioux valley.

Sporobolus asper, (Michx.) Kunth. Rough Rush-grass.

Abundant in the James and Missouri river valleys; occasional throughout the state.

Sporobolus vaginatlorus, (Torr.) Vasey. Sheathed Rusli-grass.

It occurs in the Sioux and the James river valleys; rare. 
Sporobolus ceuspidatus, Torr. Prairie Rush-grass.

In dry soils throughout the state.

Sporobolus neglectus, Nash. Small Rush-grass.

In the Minnesota region. Collected but once along an old Indian trail.

Sporobolus airoides, Torr. Hair-grass. Dropseed.

In the Missouri river to the Black Hills.

Sporobolus reyptandrus, ('Torr.) Gray. Sand Dropseed.

In sandy soil from the Missouri river eastward.

Sporobolus heterolepis, Gray. Northern Dropseed.

In low prairies throughout the state from the Missouri river eastward. In the Minnesota region it often forms a large part of the lowland hay.

Sporobolus asperifolius, (Nees \& Meyen.) Thurber. Rough-leaved Dropseed.

In dry soils from the James river valley westward.

Ciuna Arundinacea, L. Wood Reed-grass.

In the southern part of the Sioux valley.

Cimma latifolia, (Trev.) Griseb. Slender Wood Reedgrass.

Cinna Penaula, Trin.

In woods in the Sioux valley near Brookings.

Agrostis alba, L. Red-top.

Sparingly introduced in the Minuesota and Sioux river valleys.

Agrostis excrata, Trin. Rough-leaved Bent-grass.

In the Black Hills.

Agrostis canina, L. Brown Bent-grass.

In the Missouri river valley; rare.

Agrostis perenuans, (Walt.) Tuckerm. Thin-grass.

In rich woods in the Minnesota valley and the Black Hills. 
Agrostis hyemalis, (Walt.) B. S. P. Rough Hair-grass. Agrostis scabra. Willd.

A rather uncommon grass from the Missouri river eastward.

Calamagrostis macomniana, Vasey, Macoun's Reedgrass.

From the Missouri river eastward.

Calamagrostis Camadensis, (Michx.) Beauv. Blue Joint.

Common in low places, from the Missouri river eastward.

Calamagrostis breviseta, (Gray.) Scrib. Pickering's Reed.grass.

Calamagrostis sylvatica breviseta. Gray.

In the Black Hills.

Calamagrostis confinis, (Wild.) Nutt. Bog Reed-grass.

In the Minnesota and Sioux valleys.

Calamagrostis neglecta, (Ehru.) Gaertn. Narrow Reedgrass.

Calamagrostis stricta. Beauv.

In the Sioux valley, near Brookings.

Calamagrostis Montanensis, Scrib. Montana Reedgrass.

Occasional in the Sioux and James valleys.

Calamovilfa longifolia, (Hook.) Hack. Long-leaved Reed-grass.

Calamagrostis longifolia. Hook.

In dry soils throughout the state.

Avena Striata, Michx. Purple Oats.

In the Black Hills.

Avena fatua, L. Wild Oats.

Introduced in the Minnesota and Sioux valleys.

Arrhenatherum Elatius, (L.) Beauv. Oat-grass.

Escaped from cultivation near Brookings. 
Danthoua spicata, Beauv. Wild Oat-grass.

In the Black Hills.

Spartina Cymosuroides, (L.) Willd. Tall Marsh-grass.

In swamps and streams throughout the state.

Spartina dracilis, Trin. Inland Cord-grass.

In alkaline soils along Cheyenne river in the $\mathrm{Bad}$ Lands and along Lake Traverse.

Srochommardus paniculatus, (Nutt.) Trelease. Schedonnardus.

Found occasionally along trails from the Missouri river to the Black Hills, also in the soutlern part of the state east of the river.

Bonteloua hirsuta, Iag. Hairy Mesquite-grass.

In dry soils throughout the state, but inuch less common than the next.

Bonteloua oligostanchyil, (Nutt.) Torr. Mesquite-grass.

Very abundant throughout the state; commonly called "False Buffalo Grass."

Bouteloua Curtipendula, (Michx.) Torr. Racemed Bouteloua.

Common throughout the state.

Beckmannia erucaformis, (L.) Host. Beckmannia.

In wet places throughout the state.

Bulbilis dactyloides, (Nutt.) Raf. Buffalo-grass.

Throughout the state. It is rapidly disappearing in the eastern and southern part of the state.

Mumroa squarrosi, (Nutt.) Torr. Munro's grass.

On the dry plain from the Missouri valley westward.

Phragmites Phragmites, (L.) Karst. Reed-grass.

In swamps and along the edges of streams from the Missouri river eastward.

Diplacinne fiscicularis, (Lam.) Beauv. Salt-meadow Diplachne.

In alkaline Marshes east of the Missouri river. 
Eragrostis pilosa, (L.) Beauv. Tufted Eragrostis.

Sparingly introduced into the eastern and southern part of the state.

Eragurostis purshii, Schrad. Pursh's Eragrostis.

In the eastern part of the state.

Eragrostis Ma.jol, Host. Strong-scented Eragrostis.

Common east of the Missouri, rare in the Black Hills.

Eragrostis hypnoides, (Lam.) B. S. P. Creeping Eragrostis.

Common on sandy shores east of the Missouri river.

Eatonia obtusata, (Michx.) Gray. Blunt-scaled Eatonia.

East of the Missouri and in the Black Hills.

Eatonia Pennsylvanical, (Dc.) Gray. Penusylvanian Eatonia.

East of the Missouri and in the Black Hills.

Kíoeleria cristata, (L.) Pers. Koeleria.

Common from the Missouri river westward to the Black Hills.

Catabrosia acpatica, (L.) Beauv. Waterwhirl-grass.

In swamps in the Black Hills.

Distichlis spicata, (L.) Greene. Marsl Spike-grass.

Common in low alkaline soils throughout the state.

Dactylis glomerata, L. Orchard-grass.

Sparingly introduced in pastures in the extreme eastern part of the state and in the Black Hills.

Poa complessa, L. Wire-grass.

In dry places east of the Missouri river.

Poa pratensis, L. Kentucky Blue-grass.

Introduced into meadows and lawns east of the river; probably native in the Black Hills.

Poil pseudoplatensis, Scrib. \& Ryd. Prairie Meadowgrass.

Found near Hot Springs, in the Black Hills. 
Poa trivialis, L. Rough Meadow-grass.

Sparingly introduced in the vicinity of Bruokings.

Poal flava, L. False Red-top.

In swampy places in the extreme eastern part of the state; the Sioux and Little Minnesota valleys.

Poal nemoralis, L. Wood Meadow-grass.

On moist banks in the Sioux and James river valleys and in the Black Hills.

Poil debilis, Torr. Weak Spear-grass.

In wooded ravives in the Minnesota valley.

Poa alsodes, Gray. Grove Meadow-grass.

In damp woods in the Little Minnesota valley and in the Black Hills.

Poa arida, Vasey. Prairie Spear-grass.

In the Sioux and James valleys.

Poa alpina, L. Alpina Spear-grass.

Near Hot Springs, in the Black Hills.

Poal Buckleyaua, Nash. Buckley's Spear-grass.

In dry soils near Hot Springs.

Poil larvis, Vasey. Smooth Poa.

Extends from the Missouri valley to the Black Hills.

Poalfendleriana, (Steud.) Vasey. Fendler's Poa.

In the Black Hills.

Poal nevedensis, Vasey. Nevada Poa.

In the Black Hills.

Poa anmua, L. Annual Meadow-grass.

Elk Canon, in the Black Hills.

Panicularia nervata, (Willd.) Knutze. Nerved Mannagrass.

Glyceria nervata. Trin.

In the Sioux and Little Minnesota valleys, and in the Black Hilis. 
Panicularia Imericana, ('Turr.) McM. Reed Meadowgrass.

Glyceria grandis, S. Wats.

Occasional in the Sioux valley and in the Black Hills.

Panicularia fluitans, (L.) Kuntz. Floating Meadow. grass.

Glyceria fuitans. R. B.

In shallow water in the Sioux valley.

Festucar octoflora, Walt. Slender Fescue.

In dry sandy soil from the James valley to the Black Hills.

Festucal ovina, L. Sheep's Fescue.

Grows in bunches on dry prairies in the Black Hills.

Festuca Nutaus, Willd. Nodding Fescue.

On shady bluffs in the Sioux and Little Minnesota valleys.

Bromus riliatus, L. Fringed Brome.

In thickets in the Sioux, James and Little Minnesota valleys, and in the Black Hills.

Bromus Kalmii, Gray. Kalm's Chess.

In the Black Hills.

Bromus pintpellianus. Scribner.

In the Black Hills.

Agropyrou reiens, (L.) Beanv. Cough-grass, "Quack". grass.

A most troublesome weed in cultivated fields east of the Missouri river.

Agropyron violaceum, (Horn.) Vasey. Purplish wheatgrass.

Found occasionally on high ground, from the Missouri valley eastward. Specimens collected by Dr. Rydberg in the Black Hills were doubtfully referred to Agropyron violacenm majus. 
Anropyron spicatum, (Pursh.) Scrib. \& Smith. Western Wheat-grass. Alkali-grass.

Throughout the state. In the James and Missouri valleys it forms a great portion of the forage. It prefers a damp, heavy, somewhat alkaline soil. It is not common on the prairies in the eastern part of the state, but is becoming more abundant where the land is broken.

Asropyron tencrum, Vasey. Slender Wheat-grass.

Common on dry prairies throughout the state.

Agropyron strygosmu, Beauv. Rough Wheat-grass.

In sterile soil along Indian creek in the Bad Lands.

Anropyron caninum, $\left(L_{1}\right)$ R. \& S. Awned Wheat-grass.

Common in the Sioux valley and in the Black Hills, probably throughout the state.

Holdemu Iubatum, L. Squirrel-tail-grass.

A very common and troublesome weed in all waste places throughout the state.

Elymus striatus, Willd. Slender wild rye.

On banks of streams from the Missouri valley eastward, and in the Black Hills.

Elymus virginicus, L. Terrell-grass; wild rye.

Common along streams throughout the state.

Elymus canadensis, L. Nodding wild rye.

Common along streams throughout the state. Most of the material from the arid regions west of the Missouri river and in the Black Hills belongs to the variety Glaucifolius Torr.

Elymus Macomui, Vasey. Macoun's wild rye.

In the Little Minnesota valley.

Elymus Elymoiles, (Raf.) Swezey. Long-bristled wild rye.

From the Missouri river westward; rare.

Elymus dasystalohs, Trin. Western wild rye.

In the Black Hills. 
Cyperace. . - The Sedge Family.

Cyperus inflexus, Muhl. Awned Cyperus.

Cyperus Arstatus, of Manuals.

In damp sandy soil from the Missouri river eastward.

Cyperus Schwrinitzii, Torr. Schweinitz Cyperus.

In low, moist ground from the Missouri valley eastward.

Cyperus acuminatus, Torr. \& Hook. Short-pointed Cyperus.

In wet meadows throughout the state.

Cyperus erythrorhizos, Muhl. Red-rooted Cyperus.

In the Sioux and James valleys.

Cyperus strigosus, L. Straw-colored Cyperus.

In wet meadows in the little Minnesota valley.

Cyperus ovularis, (Michx.) Torr. Globose Cyperus.

In the Sioux and Little Minnesota valleys.

Elcocharis Englemanui. Steud. Englemann's Spikerush.

In wet soil from the Missouri valley eastward. There are several specimens in the College herbarium labelled E. Ovata. The plants all have the pointed spike, the low broad tubercle covering the top of the achene and the short bristles of E. Englemanni.

Eleocharis palustris, (L.) R. \& S. Creeping Spikerush.

In swamps and ponds in the Black Hills, James, Sioux and Little Minnesota valleys; and in the southern part of the Missouri valley.

Eleorhatis acoicularis, (L.) R. \& S. Needle Spike-rush.

In wet soils from the Missouri valley eastward and probably throughout the state.

Elcorhalis acuminata, (Muhl.) Nees. Flat-stemmed Spike-rush.

In the Black Hills near Hot Springs. 
Eleocinaris intermedia, (Mull.) Schuttes. Matted Spike. rush.

In springy marshes in the Sioux valley, near Brookings; rare.

S(cirpus pauciflorus, Lightf. Few-flowered Club-rush.

In the Black Hills, near Custer.

Sriupus debilis, Pursh. Weak-stalked Club-rush.

In the Missouri valley, in Potter and Walworth counties.

Sciupus Amcricanus, Pers. Three-squares.

Scirpus pungeus, Vahl.

In orackish, or fresl water swamps throughout the state; rare in the Black Hills.

Sroirpus lacoustris, L. Great Bulrush.

In lakes and ponds throughout the state.

Srirpus fluviatilis, (Torr.) Gray. River Bulrush.

On sandy shores of lakes and ponds, and along slow streams from the Missouri valley eastward throughout the state. In one locality "between 600 and I,000 acres came up in June, I 894, and yielded from $I 6$ to 25 bushels per acre of seed, which was used for feed for stock and chickens."

Scirpus atrovireus, Muhl. Dark-green Bulrush.

In swamps in the Sioux and Little Minnesota valleys.

Scirpus atrovirens pallidus, Britton. Pale Sedge.

In the Black Hills.

Scirpus cyperinus, (L،.) Kunth. Wood-grass.

In the Black Hills, near Custer.

Erophorum polystarhyon, L. Tall Cotton-grass.

In springy bogs in the Sioux valley. Watertown, Toronto, Elkton.

Eviophorum wriarila, Kock. Slender Cotton-grass.

Collected in a springy bog in the extreme eastern part of the state, near Elkton. 
Carex Iubuliformis, Sartwell. Hop-like Sedge.

In swamps and lake margins in the Little Minnesota and Sioux valleys; forming a considerable of the forage on low ground. ,

Carex festiva, Dewey. Festival Sedge.

Very rare, in the Black Hills.

('arex utriculata, Boott. Bottle Sedge.

In marshes in the Little Minnesota and Sioux valleys and in the Black Hills.

Carex hystricina, Muhl. Porcupine Sedge.

In springy swamps in the extreme eastern part of the Sioux valley.

Carex monile, Tuckerm. Necklace Sedge.

In a springy bog near Elkton; the extreme eastern part of the Sioux valley.

Cirex retrorra, Schwein. Retrorse Sedge.

In wet meadows in the Sioux and James valleys.

Carex fuenda-ryperus, L. Cyperous-like Sedge.

In low swails and margins of ponds in the Sionx valley.

('arex trirlionarpal, Muhl. Hairy-fruited Sedge.

In lakes and marshes in the Little Minnesota, the Sioux, and the southern part of the Missouri valley.

('arex aristata, R. Br. Awned Sedge.

In swamps in the Sioux valley.

C'arex Iloughtonii, Torr. Houghton's Sedge.

On dry banks in the Sioux valley near Bronkings.

G'arex Ianuginusa, Michx. Woolly Sedge.

In springy swamps in the Little Minnesota, the Sionx and the southern part of the James and Missonri valleys.

G'arex filiformis, L. Slender Sedge.

In the Sioux valley near Brookings. 
Carex stricta, Dewey. Tussock Sedge.

In low meadows in the Sioux and James valleys, and the southern part of the Missouri valley.

C'arex Haydenii, Dewey. Hayden's Sedge.

In sloughs in the Little Minnesota, Sioux and the James valleys.

Carex Nebraskensis, Dewey. Nebraska Sedge.

In the Black Hills near Custer.

Carex longirostris, Torr. Long-beaked Sedge.

On damp shady banks in the Little Minnesota and Sioux valleys and in the Black Hills.

Carex Assiniboinensis, W. Boott. Assiniboia Sedge.

On damp shady banks in the Little Minnesota, and the northern part of the Sioux valley.

C'arex capillaria, L. Hair-like Sedge.

On moist shady banks bordering streams in the Little Minnesota valley.

('arex grisea, Wahl. Gray Sedge.

In low woods in the Sioux valley near Brookings.

Carex tetallica, Schk. Wood Sedge.

In low ground in the Sioux valley.

C'arex Meadii, Dewey. Mead's Sedge.

In wet meadows in the Sioux valley near Brookings.

Calox laxifloral blanda, (Dewey.) Boott. Loose-flowered Sedge.

In damp woods near lakes in the Little Minnesota and Sioux valleys.

Carrx aura, Nutt. Golden-fruited Sedge.

In the Black Hills, near Lead.

('il'r Richandsonii, R. B. Richardson's Sedge.

In the Sionx and Janes valleys and in the Black Hills, not abundant. 
Carex pedicellata, (Dewey.) Britton. Fibrous-rooted Sedge.

On blufts in the Little Minnesota valley; rare.

Camex Penusylvanica, Lam. Pennsylvania Sedge.

Very abundant in dry soils, both open and shaded. From the Missouri valley eastward, and in the Black Hills, probably throughout the state.

Carex varia, Muhl. Emmons' Sedge.

In dry suils in the Black Hills.

Carex filifolia, Nutt. Thread-leaved Sedge.

In dry soil throughout the state, more abundant in the central and western part.

Carex stenophylla, Wahl. Involute-leaved Sedge.

In dry soil throughout the state. This plant and C. Penusylvanica form not an inconsiderable amount of early forage.

Carex Marcida, Boott. Clustered Field Sedge.

In the Little Minnesota valley and in the Black Hills.

Carex gravida, Bailey. Heavy Sedge.

On low ground in the Sioux valley.

Carex vulpinoillea, Michx. Fox Sedge.

In the Sioux, James and Missouri valleys.

Carex Sartwellii, Dewey. Sartwell's Sedge.

In the Sionx and the Little Minnesota valleys.

Carex tenclla, Schk. Soft-leaved Sedge.

Near Sylvan Lake in the Black Hills.

Carex rosea, Schk. Stellate Sedge.

On damp wooded bluffs of Bigstone Lake in the Little Minnesota valley.

Carex streilis, Willd. Little Prickly Sedge.

In the Sioux valley near White. 
Carex sic(cata, Dewey. Hillside Sedge.

In the Sioux, James and Missouri valleys and in the Black Hills.

Carex tribuloides, Walil. Blunt Broom Sedge.

In the Sioux valley.

Carex tribuloides Bebloi, Bailey.

Occurs in the Black Hills.

Carex foenea, Willd. Hay Sedge.

In the Sioux valley near Brookings; rare.

Carex Deweyana, Schwein. Dewey's Sedge.

Occurs rather rarely in the Black Hills and in the Sioux valley.

Carex straminea, Willd. Straw Sedge.

In dry soils in the Sioux and Little Minnesota valleys.

Carex festucaceat, Willd. Fescue Sedge.

In the Sioux valley near Brookings.

Carex Bicknellii, Britton. Bicknell's Sedge.

Carex Straminea Crawei, Boott.

Near Hot Springs in the Black Hills; rare.

Carex sychnocephala, Carey. Dense Long-beaked Sedge.

In low meadows in the Sioux valley, near Brookings, and in the Little Minnesota valley near outlet of Bigstone Lake.

ARACE正.-The Arum Family.

Arisirnal triplıyllum, (Y.) Torr. Indian Turnip.

On moist shady banks bordering lakes and streams in the Little Minnesota and the Sioux valleys.

A(rolus (•alamus, L. Sweet Flag.

Collected in two localities in the extreme eastern part of the state. 
LEMNACE, E.-Duckweed Family.

Spirodella polyrhiza, (L.) Schleid. Greater Duckweed. In ditches, ponds and lakes throughout the state.

Lemua trisulca, L. Star Duckweed.

In ponds and pools; so far it has been collected only from the Missouri river eastward.

Lemma minor, L. Lesser Duckweed.

In ponds, lakes and stagnant water throughout the state.

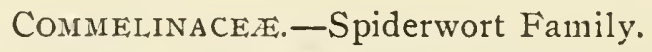

Tradescantia virginiana, L. Spiderwort.

Abundant in low moist ground throughout the state.

PONTEDERIACE正. - Pickerelweed Family.

Heteranthera limosa, (Sw.) Willd. Smaller Mud Plantain.

In muddy ponds near Dell Rapids, in the Sioux valley and at various points in the Missouri valley.

Ieteranthera dubia, (Jacq.) McM. Water Star-grass.

Schollera graminea, Gray.

In clear water from the Missouri eastward.

$$
\text { JUNCACE E. - Rush Family. }
$$

Juncus effusus, L. Bog Rush.

Common in low ground in the Sioux valley.

Juncus lufonius, L. Toad Rush.

In the Black Hills; rare.

Juncus tenuis, Willd. Slender Rush.

Common in the Sioux and the James river valleys and in the Black Hills.

Jancous Vaseyi, Englm. Vasey's Rush.

Near Hot Springs, in the Black Hills.

.Juncus longistylis, Torr. Long-styled Rush.

Near Lead City, in the Black Hills. 
Juncus nodosus, L. Knotted Rush.

In the Sioux, the Little Minnesota, and the James valleys, and the Black Hills.

Juncus Torreyi, Coville. Torrey's Rush.

In the Sioux, Minnesota, James and Missouri valleys, and in the Black Hills.

Juncus Xiphioides Iontanus, Englm. The Mountain Sedge.

A rare plant near Custer, in the Black Hills.

Juncoides comosum, (Meyer.) Sheldon. The Hairy Rush. In the Black Hills; rare.

MELANTHACE两.-Bunch-Flower Family.

Zygadenus elegans, Pursh. Glancous Zygadenus.

In low prairies probably throughout the state, the Little Minnesota, Sioux, James and Missouri valleys, and in the Black Hills.

Zygadenus venosns, S. Wats. Poisonous Zygadenus.

In the Black Hills, near Hot Springs, Rapid City, etc.

Uvularia grandiflora, J. E. Smith. Large-flowered Bellwort.

In damp shady ravines in the Little Alinnesota valley.

$$
\text { LIIIACE正.-The Lily Family. }
$$

Lencor'rinmm montanmm, Nutt. Lencocrinum.

Common in the Black Hills, Custer, Rapid City and the adjacent plains.

Allium triroccum, Ait. Wild Leek.

In damp deep ravines in the Minnesota valley.

Allium rermum, Both. Nodding Wild Onion.

In the Sioux valley and the Black Hills, abundant.

Allium stellatum, Kerr. Prairie Wild Onion.

Common in dry soils in the Sioux valley and in the Black Hills. 
Allium Camadensis, L. Meadow Garlic.

Common in low prairies in the Sioux valley.

Allium Nuttallii, S. Wats. Nuttall's Wild Onion.

In dry soils in the southern part of the James and Missouri valleys.

Allium reticulatum, Don. Fraser's Wild Onion.

On dry prairies from the Missouri river eastward and in the Black Hills.

Allium Geyeri, Wats. Geyer's Wild Onion.

In the Black Hills.

Lilium umbellatum, Pursh. Western Red Lily.

In low prairies in the Little Minnesota valley and in the Black Hills.

Fritillaria atropurpurea, Nutt. Purple Fritillaria.

In the Bad Lands region in the south central part of the state.

Calochortus Nuttallii, T., \& G. Nuttall's Mariposa Lily.

In the Black Hills.

Cahorhortus Gumuisonii, S. Wats. Gunnison's Mariposa Lily.

In the Black Hills and in the Bad Lands.

Yuccal glauca, Nutt. Bear-grass, Indian Soapweed.

Common in the dry soils, especially on bluffs from the Missouri valley to the Black Hills.

CONVALlariacE王. - Lily of the Valley Family.

Asparagus, Officinalis, L. Asparagus.

Escaped in fields and timber claims in a few places; Brookings, Yankton and Dell Rapids.

Vaguera racemosa, (L.) Morong. Wild Spiknard.

Smilacina racemosa.

On dann, shady banks in the Sioux and Little Minnesota valleys. 
Vagnera stellata, (L ) Morong. Star-flowered Solomon's Seal.

Smilacina Stellata, Nutt.

In the Little Minnesota, Sioux, James and Missouri valleys, and in the Black Hills.

Vagnela amplexicaulis, (Nutt.) Greene. Western Solomon's Seal.

Smilacina amplexicaulis, Nutt.

In the Black Hills.

Unifolium ('anadense, (Desf.) Greene. False Lily-of-theValley.

Majanthemum Canadense, Desf.

In shady woods in the Minnesota valley and in the Black Hills.

Diosporum trachycarpum, (S. Wats.) B. \& H. Roughfruited Diosporum.

Prosartes trachycarpum, S. Wats.

In shady places in the Black Hills.

Streptopus amplexifolius, (L.) Dec. Clasping-leaved 'Twist-foot.

Near Sylvan Lake, in the Black Hills.

Polygonatum Commutatum, (R. \& S.) Dietr. True Solomon's Seal.

In moist Woods from the Missouri valley eastward and in the Black Hills.

Trillium electum, L. Ill-scented Wake Robin.

In deep ravines in the Minnesota valley. Fruiting specimens were also collected in the same locality with the last which agree with $T$. Grandiflorum, but as no flowers were collected this is not reported as a certainty.

Smilacace

Smilax herbacea, L. Carrion Flower.

In woods and thickets throughout the state. 
Smilax hispida, Muhl. Hispid Greenbrier.

In the southern part of the Sioux valley from Sioux Falls southward and in the Southern Missouri valley to Running Water.

$$
\text { AMARYLLIDACE, }
$$

Hypoxis hilsuta, (L.) Coville. Star-grass.

Common on prairies in the Minnesota and Sioux valleys.

IRIDACEA.-The Iris Family.

Iris Missomriensis, Nutt. Western Flag.

In wet soils througliout the Black Hills.

Sisyrinchimm augustilolium, Mill. Pointed Blue-eyed Grass.

Common from the Missouri valley eastward and in the Black Hills.

OrCHIDACEA. - The Orchid Family.

Cyprepedium candidum, (Willd.) Small White Ladies' Slipper.

In low, damp meadows in the Minnesota and Sionx valleys.

Cyprepedium hirsutum, Mill. Large Yellow Ladies' Slipper.

In the deep, shaded ravines of the Minnesota valley.

Cyprepedium parviflormm, Salisb. Small Yellow Ladies' Slipper.

In woods in the Minnesota valley and in the Black Hills.

Habenaria hyperborea, (L.) Tall Green Orchis.

In bogs in the Little Missouri valley and in the Black Hills. 
Habenaria hacteata, (Wild.) R. Br. Long-bracted Orchis.

In damp woods in the Little Minnesota valley and in the Black Hills.

Habenaria leurophara, (Nutt.) A. Gray. Prairie Whitefringed Orchis.

In low prairies in the Sioux valley near Brookings; rare.

Gyostachys Romanzoffiana, (Cham.) MacM. Hooded Ladies' Tresses.

Spiranthes Romanzoffiana, (Cham.)

In low ground in the Sioux valley and in the Black Hills.

Peramiun repens, (L.) Salisb. Lesser Rattlesnake Plaintain.

Goodyera repens, R. Br.

In the Black Hills.

Corallorhiza Corollorhiza, (L.) Karst. Early Coralroot.

In woods in the Little Minnesota valley and in the Black Hills.

Corallorhiza multiflora, Nutt. Large Coral-root.

On shady banks in the Black Hills.

DICOTYLEDONES.

JUGLANDACEA.-Wainut Family.

Juglans nigia, L. Black Walnut.

Occurs native only in the southeastern part of the state; Union county. 
SAliCACEA⿱ - Willow Family.

Populus balsamifera, L. Balsam Poplar.

In the deep, wooded ravines of the Minnesota valley; rare. It is reported also from near Sioux Falls, but no specimens have been seen.*

Populus angustifolia, James. Narrow-leaved Cottonwood.

In the Black Hills.

Populus acuminata, Rydberg. Black Cottonwood.

Near Hot Springs in the Black Hills.

Populus tremuloides, Michx. American Aspen.

On the dry bluffs and in the spring swamps in the Minnesota valley, in the higher altitudes in the Black Hills, and in isolated patches between the Missouri river and the Black Hills. It is reported also from the Sioux valley, but no specimens liave been seen.

Populus deltoides, Marsh. Cottonwood.

Around lakes and bordering streams throughout the state; common.

Salix nigla, Marsh. Black Willow.

A shrub or small tree, common along streans in the Minuesota, Sioux and James valleys.

Salix Huviatilis, Nutt. Sand-bar Willow.

Salix longifolia, Gray.

A small, slender shrub, along streams and lakes throughout the slate; the commonest of the willows.

Salix Bebliana, Sarg. Bebb's Willow.

Salix rostrata, Richards.

In the Minnesota valley and in the Black Hills.

Salix humilis, Marsh. Prairie Willow.

Common in the Minnesota region; it is usually found on the wooded bluffs or the edge of the open prairie, acting as the advance guard of the wooled formations.

*Williams, Bulletin 43, U. S. Exp. Sta., S. D.; 105; 1895. 
Salix discolor, Muhl. Glaucous Willow.

In cold swamps in the Minnesota valley and in the Black Hills.

Salix cordata, Muhl. Heart-leaved Willow.

Along streams throughout the state.

Salix balsamifera, (Hook.) Barrett. Balsam Willow.

In the cold spring swamps in the Minnesota region.

Salix adenophylla, (Hook.) Furry Willow.

A single specimen was collected on the shores of one of the numerous lakes found in the coteaus in the northeastern part of the state, which is doubtfully referred to this species.

Silix myrtilloides, L. Bog Willow.

In the boggy swamps at the head of the coulies in the Minnesota region.

BETULACE正.-The Birch Family.

Ostrya vilginica, (Mill.) Iron-wood.

On wooded bluffs in the Minnesota region, and among the foot-hills in the Black Hills.

Corylus Americana, Walt. Hazelnut.

In thickets and open woods in the Minnesota and Sioux regions, and in the Black Hills.

Corylus rostrata, Ait. Beaked Hazelnut.

In the Black Hills, not as common as the last.

Betula papyrifera, Marsh. Canoe Birch.

Common in the Black Hills.

Betula occidentalis, Hook. Western Red Birch.

In the Black Hills; common.

Betula glandulosa, Miclix. Scrub Birch.

A low shrub, abundant in many places in the Black Hills. 
FAGACE开. - Beech Family.

Quereus macrocarpa, Michx. Burr Oak.

In rich, open woods and on dry bluffs, in the vicinity of streams or lakes throughout the state. The White Oak (Quercus $A l b a$ ) has been reported for this state, but wherever specimens were received or the locality visited, the tree proved to be one of the numerous forms of the Burr Oak. It seems very doubtful if the white oak occurs in this state.

\section{ULMaCE无.-The Elm Family.}

Ulmus Americana, L. White Elm.

Along streams and lakes throughout the state.

Ulums fulva, Michx. Slippery Elm.

Extends up the Sioux river to Sioux Falls, and up the Missouri river nearly to Chamberlain. A few trees were also found around Buffalo Lake in the northeastern part of the state, just west of the head waters of the Little Minnesota.

Celtis occidentalis, L. Hackberry.

In the vicinity of lakes and streams throughout the state.

$$
\text { MoraCE }
$$

Morus rubla, L. Red Mulberry.

This tree is found naturally only in the extreme southeastern county of the state, along the Sioux river; Elk Point.

Humulus Lupulus, L. Hops.

In thickets bordering streams and lakes throughout the state.

Canmabis sativa, L. Hemp.

Sparingly introduced into the state from the Missouri river eastward. 
URTICACE无.-Nettle Family.

Crotical gracilis, Ait. Slender Nettle.

In thickets and low ground throughout the state.

Urticastrum divaricatum, (L.) Kuntze. Wood Nettle.

Laportea Canaciensis, Gaud.

In low, rich woods from the Missouri river eastward.

Adicea Pumila, (L.) Raf. Clearweed.

Pilea pumila, Gray.

In damp, shady ground in the Minnesota and Sioux valleys.

Parietaria Pennsylvanica, Muhl. Pennsylvanian pellitory.

In shady woods from the Missouri eastward, and in the Black Hills.

SANTALACEA.-Sandal-wood Family.

Comandra umbellata, (L.) Nutt. Bastard Toad-flax.

On dry, gravelly bluffs from the Missouri valley eastward.

Comandra pallicla, A. Dc. Pale Comandra.

From the Missouri river westward throughout the state, including the Black Hills.

\section{POI.YgONACE \&.--Buckwheat Family.}

Eriogonum anmum, Nutt. Annual Eriogonum.

In the Black Hills, and also extending over most of the plains region from the Missouri valley westward.

Eriogonum multiceps, Nees. Branched Eriogonum.

On the dry plains from the Missouri river westward, and in the Black Hills.

Eriogonmm pauciflorum, Pursh. Few-flowered Eriogonum.

In the Black Hills, and in the surrounding plain region. 
Eriogonum flavum, Nutt. Yellow Eiriogonum.

In the Black Hills.

Rumex acetosella, L. Sheep Sorrel.

A European weed introduced into pastures and timber claims, etc., in the Sioux valley and in the Black Hills.

Rumex venosus, Pursh. Veined Dock.

From the bluffs of the Missouri river westward, including the Black Hills.

Rumex altissinus, Wood. Peach-leaved Dock.

Common along streams and in wet ground from the Missouri valley eastwaid.

Rumex salicifolius, Weinm. Pale Dock.

In low ground near lakes and streams throughout the state.

Rumex Britamica, L. Great-water Dock.

In the Minnesota and Sioux valleys.

Rumex occidentalis, S. Wats. Western Dock.

On the plains west of the Missonri river, and in the Black Hills.

Rumex crispus, L. Curled Dock.

Sparingly introduced into the state from the Missouri river eastward, and in the Black Hills.

Rumcx persicarioides, L. Golden Dock.

Abundant on damp, shady shores from the Missouri valley eastward.

Polygonum viviparum, L. Alpine Bistort.

In damp, mossy places in the Black Hills.

Polygonmm amphibium, L. Water persicaria.

In shallow water in the Minnesota, the Sioux and the James valleys.

Polyanum Ilatwrightii, Gray. Hartwright's Persicaria.

In the Sioux valley; rare. 
P’olygonum emersum, (Mich.) Britton. Swamp Persicaria.

In swamps and edges of ponds throughout the state.

Polygonum lapathifolium, L. Dock-leaved Persicaria.

In waste places throughout the state; rare west of the Missouri, except in the Black Hills.

Polygonum lapathifolium incanum, (Schmidt.) Kock. Same range as the type.

Polygonum Pennsylvanicum, L. Penusylvania Persicaria.

In moist soil from the Missouri valley eastward.

Polygonum Persicaria, L. Ladies' Thumb.

Common in waste places from the Missouri valley eastward, and in the Black Hills.

Polygonmm hydropiper, L. Smart-weed.

In moist places in the Minnesota and Sioux valleys.

Polygonum punctatum, Ell. Water Smart-weed.

Polygonum acre, H. B. K.

In cold swamps in the Minnesota valley.

Polygonum avirulare, L. Knot-grass.

In waste ground throughout the state.

Polygonum littorale, Link. Shore Knot-weed.

In waste places in the Black Hills.

Polygonum erectum, L. Eirect Knot-weed.

In dry soils throughout the state.

Polygonum ramosissimmm, Michx. Bushy Knot-weed.

A common weed in dry soils, throughout the state.

Polygonum campormm, Meisv. Prairie Knot-weed.

On prairies from the Missouri river eastward.

Polygonum tenue, Michx. Slender Knot-weed.

In ground that has been broken from the Missouri river eastward. 
Polygomum Iomglassii, Greene. Douglas Knot-weed.

In the Black Hills and near Sand Lake in the James valley.

Polygonum Comvolvulus, L. Black Bind-weed.

A most troublesome weed in cultivated ground throughout the state.

Polygonum s'aludens, L. Climbing False Buckwheat.

In thickets from the Missouri river eastward.

Polygonum Sawachense, Small. Western Persicaria.

Near Custer, in the Black Hills.

Chenopodiace死. - The Goosefoot Family.

Chenoporium album, L. Lamb's-quarter. Pigweed.

A weed naturalized in waste places throughout the state.

C'henoporlium wlanrum, L. Oak-leaved Goosefoot.

A weed naturalized; it prefers low, alkaline soils; in the Minnesota and Sioux valleys.

Chenopodium leptophyllum, (Moq.) Nutt. Narrowleaved Goosefoot.

In the Black Hills.

('hemopodium leptophyllum oblongifolimm, Wats. The Oblong-leaved Chenopod.

Near the Cheyenne river, east of the Black Hills.

Chenopodium Boscianum, Moq. Bosc's Goosefoot.

In woods in the Minnesota region.

C'henopodium Fremontii, S. Wats. Fremont's Goosefoot.

In damp woods in the Black Hills.

Chenopodium Fremontii incanmm, S. IVats. In the Black Hills.

Chenopodium hybridum, L. Maple-leaved Goosefoot.

In open woods in the Minnesota and Sioux valleys, and in the Black Hills. 
Chenopodium rubrum, L. Red Goosefoot.

In low, alkaline soils in the Sioux, Minnesota and James valleys.

Blitum capitatum, L. Strawberry Blight.

Chenopodium capitatum, (L.) Wats.

In the Black Hills.

Cycloma atriplicifolium, (Spreng.) Coult. Cycloma. Cycloma platyphyllum, Moq.

In the foot-hilis of the Black Hills, and the adjacent plains region; Rapid City, etc.

Monolepos Nuttaliana, (R. \& S.) Greene. Monolepis. Monolepis chenopodioides, Moq.

In alkaline soils in the Black Hills, and from there eastward to the Missouri river.

Atriplex hastata, L. Halbert-leaved Orache.

In low, alkaline places throughout the state.

Atriplex argentea, Nutt. Silver Orache.

In alkaline soils from the Missouri river westward.

Atriplex canescens, (Pursh.) James. Bushy Atriplex.

Abundant in alkaline soils from the Missouri river westward; not yet reported from the Black Hills.

Eurotia lanata, (Pursh.) Moq. White Sage.

In the Bad Lands, just east of the Black Hills.

Corispermum hysopifolium, L. Bug-seed.

In the Bad Lands, east of the Black Hills.

salicornia herbacea, L. Slender Glasswort.

In low, alkaline meadows in the Minnesota region near Wilmot, and in the James valley near Iroquois.

Dondia depressa, (Pursh.) Britton. Western Blight.

In alkaline soils with the last throughout the state.

Salsola tragus, L. Russian Thistle.

In waste places throughout the state, but most abundant in the James and the Missouri valleys. A very 
troublesome weed in waste places, but easily destroyed by cultivation. When young and tender it is readily eaten by sheep.

AmARAN'THACEA.-Amaranth Family.

Amarantlus retroflexus, I. Rough Pigweed.

An introduced weed in waste soil throughout the state, but not common in the central and western part.

Amaranthus hybridus, L. Slender Pigweed.

A naturalized weed in waste places fron the Missouri river eastwatd, less common than the last.

Amarantlus blitoides, S. Wats. Prostrate Amarantli.

In cultivated and waste fields from the Missouri river eastward.

Amaranthus grapcizans, L. Tumbleweed.

A common weed in cultivated ground throughout the state.

Acnida tamariscina, (Nutt.) Wood. Western Waterhemp.

Occasional in swamps and low places, which are somewhat brackish, from the Missouri river eastward.

Acnida tamarascina tuberculata, (Moq.) Uline \& Bray. Tubercaled Water-hemp.

Same range as the last.

NyCTAGINACE无.-Four-o'clock Family.

Allionia nyctaginea, Michx. Heart-leaved Umbrellawort.

In thickets throughout the state.

Allionia albida, Walt. Pale Umbrellawort.

In the Black Hills.

Allionia hilsuta, Pursh. Hairy Unbrellawort.

In dry soil throughout the state. 
Allonia Iincaris, Pursh. Narrow-leaved Umbrellawort. In dry soil from the Missouri valley westward.

Abronia fragrans, Nutt. White Abronia.

In the Bad Lands, east of the Black Hills.

$$
\text { PORTUlaCACEA.-Purslane Family. }
$$

Talium tretifolium, Pursh. Fame-flower.

On dry, rocky hills in the Sioux valley near Dell Rapids, and in the Black Hills.

Claytonia perfoliata amplectens, Greene. Spauish Lettuce.

In the Black Hills.

Portulacar oleracea, L. Pursley. Purslane.

Au introduced weed in cultivated grounds throughout the state.

CaryophylateE

Silena Noctiflora, L. Night-flowering Catchfly.

An introduced weed, occurring occasioually in the Sioux valley.

Lychinis alba, Mill. White Champion.

Sparingly introduced near Brookings.

Lychinis Drmmmondii, (Hook.) S. Wats. Drummond's Pink.

In the Black Hills, Custer and Rapid City.

Saponaria officinalis, L. Soapwort, Bouncing Bet.

Escaped from cultivation in the Sioux valley.

Vaccallat vacearia, (L.) Britton. Cow-herd.

Saponaria vaccaria, L.

Occurs occasionally in the Sioux and Minnesota valleys, and in the Black Hills.

Asine media, L. Chickweed.

Stellaria media, Cyr.

Sparingly introduced in the Sioux valley. 
Alsine longifolia, (Muhl.) Britton. Long-leaved Stitchwort.

Stellaria longifolia, Muhl.

In the Minnesota and Sioux valley, and in the Black Hills.

Alsine borealis, (Bigel.) Britton. Northern Stitchwort.

Stellaria borealis, Bigel.

In cold bogs in the Minnesota and the extreme eastern part of the Sioux valley, Elkton; rare.

Agrostemma Githago, L. Corn Cockle.

In grain fields from the Missouri river eastward.

Silena acaulis, L. Moss Champion.

In the Black Hills, Rapid City.

Silena stellata, (L.) Ait. Starry Champion.

In woods in the southern part of the Sioux valley; Flandreau, Sioux Falls.

Sileni vulgaris, (Moench.) Garcke. Bladder Champion.

An introduced weed in the Sioux valley near Brookings.

Silena antirrhiua, L. Sleepy Catchfly.

Occasional in low prairies in the Minnesota, Sioux and James valleys, and in the Black Hills.

('elastium Iomgipedunculatum, Muls. Powderhorn.

Abundant in moist shade in the Black Hills.

Cerastium brachypodium, (Englm.) Robinson. Shortstalked Chickweed.

From the Missouri river eastward, and in the Black Hills.

C'erastiun alvense, L. Field Chickweed.

Same range as the last, but more abundant.

corastium arvense oblongifolium, (Torr.) Holl. \& Brett.

Occasional in the Sioux, the James valley, and in the Black Hills. 
Arenaria Hookrrii, Nutt. Hooker's Sandwort.

In dry, rocky soil in the Black Hills, and the adjoining hilis and buttes.

Arenaria verna, L. Vernal Sandwort.

In shady, rocky soil in the Black Hills.

Arenaria stricta, Michx. Rock Sandwort.

In sandy soil in the Black Hills.

Molnoingia lateriflora, (L.) Fenyl. Blunt-leaved Sandwort.

Arenaria lateriflora, L.

In rich, shady soil in the Minnesota valley, and in the Black Hills.

Spercula arvensis, L. Spurey.

A naturalized weed, sparingly introluced in the Sioux valley.

Paronychia Jamesii, T. \& G. James' Whitlow-wort.

On dry soil in the Black Hills, and the surrounding plains.

NyMPH瓜ACE无, - Water Lily Family.

Nymphara advena, Soland. Large Yellow Pond Lily. Nuphar advena, R. Br.

In ponds and streams throughout the state, except in the dryer part of the plains region.

Nympliara oderata, (Dryand.) Woods \& Wood. Pond Lily.

Quite authentic reports have been received of the occurrence of this species in a tributary of the Sioux river southeast of Brookings, in the extreme eastern part of the state, but no specimens have been seen.

\section{Cera'tophyllace正.}

Ceratophyllum demersum, L. Hornwort.

One of the most abundant plants in ponds, lakes and slow streams, from the Missouri river eastward. 
Ranunculace无.-The Crowfoot, or Buttercup Family.

Caltha palustris, L. Narsh Marigold.

In cold, springy swamps and low meadows in the Minnesota valley.

Actiea rulura, (Ait.) Willd. Red Baneberry.

In rich woods near lakes and streams in the Sioux valley, and in the Black Hills.

Actrea rubra arguta, (Nutt.) Greene. Western Baneberry.

Occurs in the Black Hills.

Actiea alba, (L.) Mill. White Baneberry.

In the Sioux valley with the last species.

Aquilegia Canadensis, L. Wild Columbine.

On damp, shady banks in the vicinity of lakes and streams in the Minnesota, Sioux, James, and the southern part of the Missouri valleys, and in the Black Hills.

Aquilegia Canadensis formosa, (Fisch.) Cooper.

Occurs rarely in the Black Hills.

Aquilegia brevistyla, Hook. Small-flowered Columbine.

On shady banks in the Black Hills.

Delphinium Carolinianum, Walt. Carolina Larkspur.

Common in open ground from the Missouri eastward.

Delphinium bicolor, Nutt. Mewzie's Larkspur.

A variable species, common in the Black Hills.

Delphinium urceolatum, Jacq. Tall Larkspur.

A single fragmentary specimen was received from Rapid City in the spring of 1898 , which is very doubtfully referred to this species.

Aconitum Fischeri, Reich. Fisher's Monkshood. Wolfsbane.

In damp ravines in the Black Hills.

Anemone Caroliniana, Walt. Caroline Anémone.

On prairies, especially in low places from the Missouri eastward. 
Anemone multifida, Poir. Red Wind Flower.

Occurs only in the Black Hills.

Anemone cylindrica, A. Gray. Long-fruited Anemone.

On prairies throughout the state.

Anemone virginiana, L. Tall Anemone.

In open woods in the Minnesota and Sioux valleys.

Anemone Canadensis, L. Canadian Anemone.

In low ground, especially in the vicinity of woods or thickets, from the Missouri eastward.

Pulsatilla hirsutissima, (Pursh.) Britton. Pasque Flower,

Anemone patens Nutalliana, Dc.

Throughout the state; especially abundant on sandy bluffs and hills from the Missouri river eastward; one of the earliest flowers that blooms on the open prairie. Quite severe losses occasionally occur to the sheep industry by the formation of "hair balls" in the stomach of sheep which have eaten too greedily of this plant. The trouble most often occurs early in the spring, before the grasses have made much growth.

Clematis Virginiana, L. Virginian Virgin's Bower.

Along streams and lakes in the Sioux, James and Minnesota valleys.

Clematis ligusticifolia, Nutt. Western Virgin's Bower.

In thickets along streams from the Missouri westward.

Clematis Scottii, Porter. Scott's Clematis.

In the Black Hills.

Clematis alpina tenuiloba, (Gray.) Rydberg. Alpine Clematis.

Occurs occasionally in canons in the Black Hills.

Myosurus minimus, L. Mouse-tail.

Occurs in low places in several localities in the James river valley, from the central part of the state southward; Kingsbury, Miner and Aurora counties. 
Ranunculus delphinifolius, Torr. Yellow Water-crowfoot.

Ranunculus multifidus, Pursh.

In ponds and streams from the Missouri river eastward.

Ranumculus ovalis, Raf. Prairie Crowfoot.

Ranunculus rhomboideus, Goldie.

On prairies and banks of streams throughout the state.

Ranunculus abortivus, L. Kidney-leaved Crowfoot.

In rich woods in the Minnesota and Sioux valleys, and in the Black Hills.

Ranunculus sceleratus, L. Celery-leaved Crowfoot.

In the Sioux, the Minnesota and the sonthern part of the James valley, and in the Black Hills.

Ranunculus Penmsylvanicus, Lf. Bristly Buttercup.

In low, wet ground in the Minnesota, the Sioux and the James valleys, and in the Black Hills.

Ranunculus Macomii, Britton. Maconn's Buttercup.

A common species in the Minnesota, Sioux and James valleys, and in the Black Hills.

Ranunculus pedatifidus cardiophyllus, (Hook.) Britton.

Occurs in the Black Hills.

Ranunculus septentrionalis, Poir. Swamp Buttercup. Common in low, wet meadows in the Minnesota and Sioux valleys.

Batrachium divaricatum, (Schrank.) Wimm. Water Crowfoot.

Ranunculus trichophyllus, Chaix.

Common in ponds and streams throughout the state.

Oxygraphis cymbalaria, (Pursh.) Prantl. Seaside Crowfoot.

Ranunculus cymbalaria, Pursh.

In sandy soil throughout the state. 
Thalictrum diocium, L. Early Meadow Rue.

Occurs occasionally from the James valley eastward; Brown and Brookings counties.

Thalictrum venulosum, Trelease. Veiny Meadow Rue. In the Black Hills.

Thalictrum occidentale, Gray. Western Meadow Rue.

Dr. Rydberg is not quite certain of his identification of this species, as he was unable to obtain fruit.

Thalictrum purpurascens, I. Purplish Meadow Rue.

In thickets and woods throughout the state.

BERBERIDACEA. - Barberry Family.

Berberis aquifolium, Pursh. Trailing Mahonia.

Berberis repens, Lindl.

A trailing shrub, common in canons in the Black Hills.

Caulophyllum thalictroides, (L.) Michx. Blue Cohosh. in rich woods in the Minnesota region.

Menispermace死,-Moonseed Family.

Menispermum Canadense, L. Canada Moonseed.

In woods and thickets along streams from the Missouri eastward.

$$
\text { PapaVerace. }
$$

Argemone allai, Lestib. White Prickly Poppy.

In draws and on open plains in the foot-hills to the Black Hills, and ranging eastward nearly to the Missouri river.

Sanguinaria canadensis, L. Bloodroot.

In damp, rich woods in the Minnesota region.

Bicuculla cucullaria, (L.) Millsp. Dutchman's Breeches. Dicentra cucullaria, DC.

In rich woods in the Minuesota and Sioux valleys. 
('apnoidles anreum, (Willd.) Kuntze. Golden Corydalis. Corydalis aurea, Willd.

In light soil in the Minnesota and Sioux valleys, and in the Black Hills. It was collected along a railroad embankment, and was possibly introduced from farther east.

(apuoides rurvisilioum, (Englm.) Kuntze. Curvedfruited Corydalis.

Corydalis curvisiliqua, Englm.

Common in the Black Hills.

CRUCIFERE. - Mustard Family.

Stanleya pinnata, (Pursh.) Britton. Stanleya.

On dry prairies in the Black Hills region.

Lepidium virginicum, L. Wild Pepper-grass.

A weed in fields and roadsides in the Minnesota and Sioux valleys.

Lepidium apetalum, Willd. A petalous Pepper-grass.

Lepidium intermedium, Gray.

A very abundant weed in cultivated fields and waste places from the Missouri river eastward.

Lepidium incisum, Roth. Cut-leaved Pepper-grass.

Occurs rarely in the Black Hills.

Thalaspi arvense, L. Field Pepper-grass.

Sparingly introluced in the Sioux valley near Sioux Falls. Doubtless introduced from Manitoba, where it is a troublesome weed.

Sisymbrium ofticinale, (L.) Scop. Hedge Mustard.

A common weed in waste places from the Missouri river eastward.

Sisymbrium altissimum, L. Tumbling Mustard.

A common and troublesome weed in the Minnesota valley, doubtless introduced from Assinoboia.

Brassical nigra, (L.) Koch. Black Mustard.

A common introduced weed in waste places. 
Brassical arvensis, (L.) B. S. P. Wild Mustard. Brassica sinapistrum, Bois.

A troublesome weed in cultivated fields throughout the state, but more abundant in the eastern part. It is much more abundant and harder to eradicate in the bottom lands.

Sinapsis alba, L. White Mustard.

Brassica alba, Bois.

A weed in cultivated and waste places throughout the state.

Roripa siniata, (Nuct.) A. S. Hitchcock. Spreading Yellow-cress.

Occasional in low places from the Missouri valley eastward.

Roripa palustris, (L.) Bess. Marsh Water-cress.

Nasturtum palustris, DC.

In low, wet places throughout the state.

Rovipa hispirla, (Desv.) Britton. Hispid Yellow-cress. Nasturtium hispidium, DC.

Occasional in low places from the Missouri valley eastward.

Roripa nasturtium, (L.) Rusby. Water-cress.

Nasturtium officinale, R. Br.

Naturalized near Hot Springs in the Black Hills.

Roripa armoracia, (L.) A. S. Hitchcock's Horseradish. Nasturtium armoracia, Fries.

Sparingly introduced into the Sioux valley.

Camomine bulbosa, (Schreb.) B. S. P. Bulbous Cress. Cardamine rhomboida, DC.

In shallow water and low meadows in the Minnesota and Sioux valleys.

Cardamine rotumdifolia, Michx. American Water-cress.

In cold, springy bogs in the Minnesota region. 
Cardaminc pratensis, (L.) Cuckoo-flower.

Specimens collected in the cold spring swamp near Lake Traverse in the Minnesota region, one doubtfully referred to this species.

Physaria didymocarpa, (Hook.) Gray. Double Bladderpod.

On the dry plains east of the Black Hills.

Lesquerella spathulata, Rydberg. Low Bladder-pod.

On dry knolls in the Black Hills and the surrounding plains.

Lesquerella argentia arenosa, (Richards.) Wats. Silvery Bladder-pod.

Vesicaria arenosa, Richards.

In the Black Hills and the adjacent plains.

Bursa Bursa-pastoris, (L.) Britton. Shepard's Purse.

Capsella Bursa-pastoris, Medic.

Sparingly introduced from the Missouri eastward and in the Black Hills.

Camelina sativa, (L.) False Flax.

Occasional in flax fields and waste places in the Sioux valley and the Black Hills.

Draba Caroliniana, Walt. Carolina Whitlow-grass.

On dry, sandy knolls from the James valley westward.

Draba Caroliniana micrantha, (Mott.) Gray.

In the Black Hilis.

Draba nemoriasa, L. Wood Whitlow-grass.

Occasional on sandy knolls in the Sioux valley and in the Black Hills.

D1:alba anrea, Vahl. Golden Whitlow-grass.

In the Black Hills.

Sophia incisa, (Engelm.) Greene. Western Tansy Mustard.

Sisymbrium incisum, Engelm.

Occasional throughout the state. 
Sophia IIat wewiana, (Fourn.) Greene. Hastings' Tansy Mustard.

Sisymbrium Hartaegianum, Fourn.

Common in dry soil in the Sioux valley.

Arabis hirsuta, (L.) Scop. Hairy Rock-cress.

On prairies in the Minnesota, Sioux and James valleys and in the Black Hills.

Arabis Canalensis, L. Sickle-pod.

In open woods in the Minnesota valley.

Arabis Draclivandea, (T. \& G.) Britton. Purple Rockcress.

In woods in the Minnesota valley.

Arabis glabra, (L.) Bermh. Tower Mustard.

'Arabis perfoliata, L.

Occasional in the Minnesota and Sioux valleys and in the Black Hills.

Arabis Horbocllii, Hormen. Horboell's Rock-cress.

In the Black Hills.

Erysimum cheiranthoires, (L.) Treachle Mustard.

In thickets in the vicinity of streams in the Minnesota and Sioux valleys and in the Black Hills.

Erysimum imoonspicuum, (S. Wats.) MacdI. Small Erysimum.

In the Sioux valley and the Black Hills; not common.

Erysiumm syrticolum, Sheldon. Sand Erysimum.

In the Minnesota region, near Bigstone lake.

Erysimum asperum, DC. IVestern Wall-flower.

On dry soil from the Missouri valley westward.

Matthiola fenestralis, Stock.

There is a single specimen in the herbarium from Spring lake, Walworth county, with no note as to the extent to which it has become naturalized. 
Coningia orientalis, (L.) Dumort. Hare's-ear Mustard.

Sparingly introduced from the Missouri valley eastward, becoming troublesome in some localities.

\section{CAPPARIDACE无.-Caper Family.}

Cleonal serrulata, Pursh. Pink Cleome.

Cleoma integifolia, T. \& G.

From the Missouri valley westward; not abundant.

Polanisia trachysperma, T. \& G. Clammy Weed.

On sandy and gravelly shores throughout the state.

Crassulace $Æ$ - Orpine Family.

Sedum stenopetalum, Pursh. IVestern Stome Crop.

On dry, rocky knolls in the Black Hills.

Penthorum sedoides, L. Virginian Stone Crop.

Along and in streams in the Minnesota and Sioux valleys; abundant.

SAXIFRAGACEA:-Saxifrage Family.

Saxifiaga cellutu, L. Nodding Saxifrage.

Near Sylvan lake, in the Black Hills.

Heuchera hispida, Pursh. Rough Heuchera, Alum-root.

In thickets from the Missouri valley eastward, and in the Black Hills.

Heuchera parviflora, Nutt. Small Flowered Alum-root.

Near Rockford in the Black Hills.

Parmassia Caroliniana, Michx. Grass of Parnassus.

In cold swamps in the Minnesota region, and one station, near Elkton, in the Sioux valley.

Parnassial balriflora, DC. Small-flowered Grass of Parnassus.

In cold swamps in the Minnesota valley and in the Black Hills. 
Tellima parviflora, Hook. Small-flowered Tellima.

In the Black Hills, rare.

GROSSULARIACEA.-Gooseberry Family.

Ribes sualeile, Miclix. Missouri Gooseberry.

Common in woods and thickets from the Missouri val. ley eastward.

Ribes oxycanthoides, L. Northern Gooseberry.

In the Minnesota and Sioux valleys and $i n$ the Black Hills.

Ribes lacustre, (Pers.) Poir. Swamp Gooseberry.

In the Black Hills.

Ribes Setosmm, Lindl. Bristly Gooseberry.

Common in the Black Hills and along streams in the adjoining plains.

Riber Horidum, L'Her. Wild Black Currant.

Very common along streams from the Missouri valley eastward.

Ribes cereum, Dougl. Squaw Currant.

Common in the "draws" and canons in the Black Hills and the adjacent plains. Doubtless extending eastward nearly to the Missouri river.

Ribes anleum, Pursh. Golden or Buffalo Currant.

In thickets and along streams from the Missouri valley westward.

$$
\text { ROSACE正.-Rose Family. }
$$

Opulaster opulifolius, (L.) Kuntze. Ninebark.

Common in the Black Hills.

Opulaster monogyua, (Torr.) Kuntze. Small-flowered Ninebark.

In the Black Hills and the adjacent plains. 
Spirata salicifolia, L. Willow-leaved Meadowsweet.

In moist ground in the Minnesota valley, and in the Sioux valley near Sioux Falls.

Spiraca lurila, Dougl. Corymbed Spiræa.

Spirce betulifolia, Hook.

On banks in the Black Hills.

Luetkea rarspetona, (Nutt.) Kuntze. Tufted Meadowsweet.

Spirce cespitosa, Nutt.

In the Black Hills.

Rubus parviflorus, Nutt. Salmon-berry.

Rubus nutkanus, Mocino.

In the Black Hills.

Rubus strigosus, Michx. Red Raspberry.

Along streams and in rocky places throughout the state.

Rubus occirlentalis, L. Black Raspberry.

From the Missouri river eastward. In general it is not as common as the last, especially rare in the Missouri valley.

Rubus Imericanus, (Pers.) Britton. Dwarf Raspberry. Rubus triftorus, Richards.

In cold swamps in the Minnesota region and in the Black Hills.

Fragaria Virginiana, Duchesne. Strawberry.

In rather low ground throughout the state, but not abundant.

Fragaria Imericana, (Porter.) Britton. Wood Strawberry. Indian Strawberry.

Fragaria l'esca Americana, Porter.

In woods in the Minnesota region, and in the Black Hills.

Potentilla areuta, Pursh. Tall Cinquefoil.

On dry prairies throughont the state. 
Potentilla nivea dissecta, Wats. Snowy Cinquefoil.

A rare plant, occurring in the Black Hills near $\mathrm{Hot}$ Springs.

Potentilla Monspeliensis, L. Rough Cinquefoil.

Potentilla Norvegica, L.

In dry soils throughout the state.

Potentilla lencocarpa, Rydberg. Diffuse Cinquefoil.

Potentilla rivalis millegrama, $\mathrm{S}$. Wats.

In the Black Hills and the Sioux valley.

Potentilla paradoxa, Nutt. Bushy Cinquefoil.

Potentilla supina, Michx.

In sandy soil throughout the state; not abundant.

Potentilla Mippiana, Lehm. Woully Cinquefoil.

Occurs only in the Black Hills.

Potentilla hipluiana diffusa, (Gray.) Lehm.

Occurs with the type in the Black Hills.

Potentilla Penusylvanica, L. Prairie Cinquefoil.

On prairies from the Missouri valley eastward and in the Black Hills.

Potentilla finiticosa, I. Shrubby Cinquefoil.

In moist, rocky places in the Black Hills.

Potentilla anserina, L. Silver-weed.

In alkaline places from the Missouri river eastward.

Potentilla glandulosa, Lindl. Glandular Cinquefoil.

In the Black Hills.

Potentilla gracilis, Dougl. S̉lender Cinquefoil.

In the Black Hills.

Potentilla gracilis fastigiata, (Nutt.) Wats.

Near Rockford in the Black Hills.

Potentilla concinma, Richards. Elegant Cinquefoil.

Near Custer in the Black Hills.

Potentilla roncinua lumistrata, Ryd.

In the Black Hills, in the vicinity of Deadwood. 
Geum riliatum, Pursh. Long-plumed Purple Avens. Geum triflorum, Pursh.

On prairies and in thickets througliout the state.

Genn C'andensis, Jacq. White Avens.

In woods and thickets from the Missouri river eastward.

Geum Vilginianum, L. Rough Avens.

In low ground in the Minnesota and Sioux valleys.

Geum Maropphyllum, Willd. Large-leaved Avens.

Near Rockford in the Black Hills.

Gemm strictum, Ait. Yellow Avens.

Occasional throughout the state.

Cercocarpus parvifolius, H. \& A. Small-leaved cercocarpus.

On dry, rccky knolls in the Black Hills.

Agrominia hirsuta, (Muhl.) Becknell. Hairy Agrimonia. Agrimonia eupatoria hirsuta, Muhl.

In thickets in the Minnesota and James valley and in the Black Hills.

Agrimonia parviflora, Soland. Many-flowered Agrimonia.

Occasional in woods and thickets in the Minnesota and Sioux valleys and in the Black Hills.

Rosa blanda, Ait. Meadow Rose.

In thickets in the Minnesota and Sioux valleys.

Rosa acicularis. Prickly Rose.

Abuudant in the Black Hills.

Rosa woolesii, Lindl. Wood Rose.

From the James valley westward, common only in the Black Hills.

POMACE正.-Apple Family.

Sorlus sambucifolia, (C. \& S.) Roem. Western Mountain Ash. 
Pyrus sambucifolia, C. \&. S.

Doubtfully reported by Dr. Rydberg as occurring near Sturgis in the Black Hills.

Amelanchier Canalensis, (L.) Media. June Berry, Service Berry.

Along the Sioux river near Sioux Falls.

Anelanchier rotundifolia, (Michx.) Roem. Roundleaved June Berry.

Amelanchier Canadensis rotundifolia, T. \& G.

In woods and thickets in the Minnesota and Sioux valleys.

Amelanchier aluifolia, Nutt. Northwestern June Berry. Amelanchier Canadensis alnifolia, T. \& G.

In thickets and on dry knolls from the James valley westward; common.

Cratagus macracantha, Lodd. Long Spined Thornapple.

Cratcegus coccinea macracantha, Dudley.

Common in thickets in the Minnesota, Sioux' and James valleys, and in the Black Hills.

Cratiegus mollis, ('T. \& G.) Scheele. Red-fruited Thorn. Cratcegus tomentora mollis, Gray.

Occasional in thickets in the Minuesota, Sioux and James valleys.

DRUPACEA.-Plum Family.

Prumus Americana, Marsh. Wild Plum.

Very abundant in thickets in the vicinity of lakes and streams throughout the state.

Prumus Besseyi, Bailey. Western Sand Cherry.

On bluffs and banks of streams from the James valley westward.

Prunus Pennsylvanica, L. F. Pin Cherry or Wild Red Cherry.

This species has only been reported from the Black Hills. 
Prumus Virginiana, L. Choke Cherry.

Along streams and lakes throughout the state.

P'rumus demissa, (Nutt.) Walp. Western Wild Cherry.

Along streams from the Missouri valley westward.

Prunus serotina, Ehrh. Black Cherry.

Rare in the Minnesota and Sioux valleys.

\section{Mimosace, - Mimosa Family.}

Arnan Illinornsis, (Michx.) Kuntze.

Desmanthus brachylobus, Benth.

On sandy or rocky banks of streams and lakes; occasional in the Minnesota, Sioux and Janes valleys.

Morongia uncinata, (Willd.) Britton. Sensitive-brier. Schrankia uncinata, Willd.

In dry soil from the Missouri valley westward.

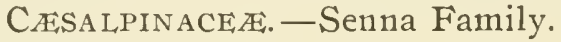

C'ercis Camadensis, L. Red-bud.

This species is reported by Engelman to be found at the mouth of the Sioux river. It has not yet been collected there or elsewhere in the state. If it reaches our southeastern limit it must be quite rare.

Cassia chaniecrista, L. Sensitive Pea.

In the southern part of the Sioux and James valleys, near Sioux Falls, Elk Point and Yankton.

Gleditsia triacanthos, L. Sweet Locust.

Along the Sioux river in the extreme southeastern county, Union county.

Gymuocladus dioica, $\left(L_{4}\right)$ Koch. Kentucky Coffee-tree.

Along the Missouri river in the two southeastern counties, Clay and Union.

$$
\text { PapillionaceA. -Pea Family. }
$$

Sophoral sericea, Nutt. Silky Sophora.

On prairies from the Missouri valley westward. 
Thermopsis rhombifolia, (Nutt.) Richards. Prairie Thermopsis.

On banks and in draws from the Missouri valley westward.

Crotalaria sagitalis, L. Rattle-box.

On prairies in the southern part of the state, east of the Missouri river; Union, Clay, Yankton and Charles Mix counties.

Lupinus sericeus, Pursh. Woolly Lupine.

In the Black Hills.

Lupinus parviflorus, Nutt. Small-flowered Lupine. Common in the Black Hills.

Lupinus pusillus, Pursh. Low Lupine.

Common on the dry plains from the Missouri valley westward.

Melilotus alba, Desv. White Sweet Clover.

Sparingly naturalized in the Minnesota, Sioux and James valleys.

Melilotus officiualis, (L.) Lam. Sweet Yellow Clover.

Escaped from cultivation in the Sioux valley near Brookings.

Trifolium procumbens, L. Low Hop Clover.

Sparingly naturalized in the Sioux valley.

Trifolium stoloniferum, Muhl. Running Buffalo Clover.

In low prairies and woods in the Minnesota and Sioux valleys; introduced.

Trifolium Beckwithii, Brewer. Beckwith's Clover.

Very abundant around swails and in low meadows in the Minnesota and Sioux valleys. Our only native clover.

Trifolium repens, (L.) White Clover.

Sparingly introduced in the Sioux valley and in the Black Hills. 
Trifolium pratense, I. Red Clover.

Sparingly naturalized in the Minnesota and Sioux valleys.

Lotus Americanus, (Nutt.) Bisch. Prairie Bird's-foot Trefoil.

Hosackia purshiana, Benth.

On low, sandy land, mostly in the vicinity of streams, locally very abundant; it is the most nutritious of all our native forage crops. In cultivation, however, its growth is uncertain. The name of "Dakota Vetch" has been applied to it by J. G. Smith.

Psoralea tenuiflora, Pursh. Few-flowered Psoralea.

Common in dry soils from the Missouri river valley westward.

Psoralea digitata, Nutt. Digitate Psoralea.

Occasional in dry soils from the Missouri river westward.

Psoralea argophylla, Pursh. Silver-leaf Psoralea.

Very abundant throughont the state.

Psoralea cuspiclata, Pursh. Large-bracted Psoralea.

Conmon on dry hills and banks from the Missouri valley westward.

Psoralea esculenta, Pursh. Prairie Turnip, "Indian Turnip."

On sandy knolls throughout the state; common.

Psoralea lanceolata, Pursh. Lance-leaved Psoralea.

In the southern part of the Sioux valley; uncommon.

Amorpha fruticosa, I . False Indigo. Lead Plant.

Bordering streains and lakes throughout the state.

Amorpha nama, Nutt. Fragrant False Indigo.

Amorpha microphylla, Pursh.

On banks and prairies from the James valley westward to the Black Hills; also reported from Sioux Falls in the Sioux valley; more abundant from the Missouri river westward. 
Anorplia cancscens, Pursh. Shoe-strings. Lead-Plant. Very abundant on prairies throughout the state.

Parosela enneandra, (Nutt.) Britton. Slender Parosela. Dalea laxiflora, Pursh.

Common from the Missouri valley to the Black Hills.

Parosela dalea, (L.) Britton. Pink Parosela.

Dalea alopecuroides, Willd.

In sandy soils from the Missouri valley eastward; occasional in the Minnesota and Sioux valleys; common in the Missouri valley.

Parosela aurea, (Nutt.) Britton. Golden Parosela.

Dalea aurea, (Nutt.)

On bluffs and locse soils from the Missouri valley westward.

Kinhuistera candida, (Willd.) Kuntze. White Prairie Clover.

Petalstemon candiaus, Michx.

Very common on prairies throughout the state.

Kuhnistera compacta, (Spreng.) Kuntze. Dense-flowered Prairie Clover.

Petalstemon compacta, Swezey.

Occasional on dry plains from the Missouri valley westward.

Kuhnistera purpurea, (Vent.) MacM. Violet Prairie Clover.

Petalstemon violaceus, Michx.

Common throughout the state; especially abundant in sandy or gravelly soils.

Kuhnistera villosa, (Nutt.) Kuntze. Hairy Prairie Clover.

Petalstemon villosus, Nutt.

In the Bad Lands, east of the Black Hills.

Astragalus crassicarpus, Nutt. Buffalo Pea, Ground Plum.

Astragalus caryocarpus, Ker.

Very common on prairies throughout the state. 
Astragalus Mexicanus, DC. Larger Ground Plum.

In the Sioux valley, near Brookings.

Astragalus Plattensis, Nutt. Platte Milk Vetch.

In the Sioux valley near Sioux Falls, and in the Black Hills.

Astragalus Carolinianus, L. Carolina Milk Vetch. Astragalus Canadensis, L.

In sandy soil and waste places in the Minnesota and Sioux valleys and in the Black Hills.

Astragalus adsurgens, Pall. Ascending Milk Vetch.

On prairies throughout the state.

Astragalus hypoglottis, L. Cock's-head.

Abundant from the Missouri valley eastward, and in the Black Hills.

Astragalus Drummondii, Dougl. Drummond's Milk Vetch.

In the Black Hills, near Hot Springs.

Astragalus racemosus, Pursh. Racemose Milk Vetch.

Abundant in heavy soils from the Missouri river westward; occasional in the James valley.

Astragalus bisulcatus, (Hook.) Gray. Grooved Milk Vetch.

In the foot-hills of the Black Hills, and in the adjoining plains.

Astragalus lotiflorus, Hook. Low Milk Vetch.

In the Black Hills and on the adjoining plains.

Astragalus Missouriensis, Nutt. Missouri Milk Vetch.

From the Missouri valley westward; common on dry banks and hills.

Astragalus gracilis, Nutt. Slender Milk Vetch.

In dry ground in the Minnesota region, and near Hot Springs in the Black Hills.

Astragalus microlobus, Gray. Notched Milk Vetch.

Common in the Black Hills. 
Astragalus flexuosus, (Hook.) Dougl. Flexile Milk Vetch.

On dry soils throughout the state.

Astragalus aborigiumm, Richards. Indian Milk Vetch. Near Deadwood, in the Black Hills.

Astragalus aboriginum glaberiusculus, (Hook.) Rydberg. Indian Milk Vetch.

In the Black Hills.

Astragalus alpiums, L. Alpine Milk Vetch.

In woods in the Black Hills.

Astranalus collvallarius, Greene.

Near Bull Spriugs in the Black Hills.

Plıaca Americana, (Hook.) Rydberg. Arctic Milk Vetch. Phaca frigida Americana, Hook.

On low ground in thickets in the Black Hills and the adjacent plains.

Homalobus tenellus, (Pursh.) Britton. Loose-flowered Milk Vetch.

Astragalus tenellus, Pursh.

Homalobus montamus, (Nutt.) Britton. Prickly Milk Vetch.

Astragalus Kentrophyta, A. Gray.

In the Bad Land region, east of the Black Hills.

Homalobus caspitosus, Nutt. Tufted Milk Vetch. Astragalus cespitosus, A. Gray.

In dry soils in the Black Hills, and in the adjacent plains region.

Orophaca caspitosa, (Nutt.) Britton. Sessile-flowered Milk Vetch.

Astragalus caspitosa, Nutt.

In dry soils from the Missouri river westward.

Spiesia Lamberti, (Pursh.) Kuntze. Loco-weed.

Orytropis Lamberti, Pursh.

Abundant on high ground throughout the state. 
Spiesia Lamberti sericea, (Nutt.) Rydberg.

Oxytropus sericea, Nutt.

Throughout the state, but more abundant from the Missouri valley westward.

Spiesia viscidla, (Nutt.) Kuntze. Viscid Loco-weed.

Common near Custer in the Black Hills.

Glycyrrhiza lepidota, Pursh. Wild Licorice. Buftalo Burr.

Very abundant in low ground throughout the state.

Hedysarum Americanum, (Michx.) Britton. Hedysarum.

In the Black Hills near Rockford.

Meilomia grandiflora, (Walt.) Kuntze. Broad-leaved Tick-trefoil.

Desmodium acuminatum, Michx.

In woods in the Minnesota and Sioux valleys and up the Missouri valley to Yankton.

Meibomia Illinoensis, (A. Gray.) Kuntze. Illinois Ticktrefoil.

Desmodium Illinoense, A. Gray.

Common in thickets and low prairies in the Minnesota valley.

Lespedeza capitata, Michx. Round-headed Bush Clover. In low, sandy soil in the southern part of the Sioux valley; Sioux Falls and Elk Point; up the Missouri to Yankton.

Vicia Americana, Muhl. Anerican Vetch.

In woods and thickets in the Minnesota and Sionx valleys and the Black Hills.

Vicia Americana trumeata, (Nutt.) Brewer.

Vicia truncata, Nutt.

In or near low ground throughout the state.

Vircial linearis, (Nutt.) Greene. Narrow-leaved Vetch.

Vicia Americana linearis, S. Wats.

Common on dry prairies throughout the state. 
Vicia sativa, L. Vetch. Tare.

Introduced into waste or cultivated fields in the Sioux valley.

Lathrius venosus, Muhl. Veiny Pea, Wild Pea.

On shady banks of streams and lakes in the Minnesota and Sioux valleys.

Lathyrus palustris, L. Marsh Vetchling.

In low, moist ground from the Missouri river eastward.

Lathyrus ornatus, Nutt. Showy Vetchling.

On banks and bluffs from the Missouri valley westward.

Lathyrus ochrolencus, Hook. Cream-colored Vetchling.

Abundant in the Black Hills.

Falcata comosa, (L.) Kuntze. Hog Peanut. Amphicarpa monoica, Ell.

Near Rapid City in the Black Hills.

Falcata Pitrheri, (T. \& G.) Kuntze. Pitcher's Hog Peanut.

Amphicarpa Pitcheri, T. \& G.

In rich woods in the Minnesota valley.

Apois apois, (L.) McM. Grounduut.

Apois tuberosa, Moench.

In woods and thickets in the Minnesota and Sioux valleys.

strophostyles helvola, (L.) Britton. Trailing Wild Bean. Strophostyles angulosa, Ell.

On shady banks of streams and lakes from the Missouri valley eastward; not common.

strophostyles pauciflora, (Benth.) S. Wats. Sinall Wild Bean.

On banks of streams and lakes in the Minnesota, Sioux and James valleys. 
GeRANIACE正-Geraniun Family.

Geranium columbinum, L. Long-stalked Crane's Bill. In the southern part of the Missouri valley; Charles Mix county.

Geranium Carolinianum, L. Carolina Crane's Bill.

In the Black Hills and the southern part of the Missouri valley.

Geranium disiectum, L. Cut-leaved Crane's Bill.

A native of Europe; near Rapid City in the Black Hills; rare.

Geranium Richardsonii, Fisch. \& Meyers. Richardson's Crane's Bill.

The common species in the Black Hills.

Geranium viscosissimum, Fisch. \& Meyers. Viscid Crane's Bill.

Occasional in the Black Hills.

OxalidacE无。--Wood-sorrel Family.

Oxalis violacea, L. Violet Wood-sorrel.

In low places in thickets and in open prairies in the Minnesota, Sioux and James valleys.

Oxalis stricta, L. Upright Yellow Wood-sorrel.

In thickets and on prairies from the Missouri valley eastward and in the Black Hills.

$$
\text { LINACEA. -Flax Family. }
$$

Linum Lewisii, Pursh. Lewis' Wild Flax.

In the Black Hills.

Linum sulcatum, Riddell. Grooved Yellow Flax.

In dry soil in the Minnesota, Sioux and James valleys.

Linum rigidum, Pursh. Large-flowered Yellow Flax.

Common on dry prairies throughout the state. 
RUTACEA.-Rue Fanily.

Ianthoxylum Americanum, Mill. Prickly Ash.

In woods along streams and bordering lakes from the Missouri valley eastward.

PolygalacE西.-Milkwort Family.

Polygala verticillata, L. Whorled Milkwort.

On bluffs and prairies throughout the state.

Polygala senega latifolia, T. \& G.

Common in the northern part of the Black Hills.

Polygala alba, Nutt. White Milkwort.

Common from the Missouri valley eastward and in the Black Hills.

\section{EUPHORBIACE E.-Spurge Family.}

Croton Texensis, (Klotzsch.) Muell. Texas Croton.

Common in dry, sandy soils from the Missouri valley westward.

Euphorbia petaloidea, Engelm. White-flowered Spurge.

In sandy soil from the Missouri valley westward to the Black Hills.

Euphorbia Geyeri, Engelm. \& Gray. Geyer's Spurge. In dry soils from the Missouri valley westward.

Euphorbia serpyllifolia, Pers. Thyme-leaved Spurge.

Common in the Minnesota, Sioux, and James valleys.

Euphorbia serpens, H. B. K. Round-leaved Spurge.

In the southern Missouri valley; Charles Mix county.

Euphorbia Glyptosperma, Engelm. Ridge-seeded Spurge.

In dry soils throughout the state; the most common species.

Euphorbia maculata, L. Milk Purslane.

In the Sioux and James valleys. 
Euphorbia stictospora, Engelm. Narrow-seeded Spurge.

Common in dry soils from the Missouri valley westward.

Euphorbia untans, Lag. Upright Spotted Spurge.

Euphorbia presliz, Guss.

In the Sioux, James and Missouri valleys, especially the eastern part.

Euphorbia hexagona, Nutt. Angled Spurge.

In dry soils from the Missouri valley westward.

Euphorhia margiuata, Pursh. White Margined Spurge.

Along the Missouri river in the southern part of the state and thence westward.

Euphorbia dentata, Michx. Toothed Spurge.

In the southern part of the Missouri valley, Charles Mix county, and in the Black Hills.

Euphorbia heteroplyylla, L. Various-leaved Spurge.

In the southern part of the Sioux and Missouri valleys; near Sioux Falls, Yankton and Running Water.

Euphorbia dictyosporma, F. \& M. Reticulate-seeded Spurge.

In the James valley near Aberdeen, and from thence westward.

Euphorbia robusta, (Engelm.) Small. Rocky Mountain Spurge.

Euphorbia mountain robusta, Engelm.

Along the Cheyenne river and in the Black Hills; probably ranging from the Missouri valley westward.

CALLITRICHACE正, -Water Starwort Family.

Callitriche palustris, L. Water Fennel.

Common in clear, cold streams throughout the state.

Callitriclue bifirla, (L.) Morong. Autumual Starwort. Callitriche autumnalis, $\mathrm{L}$.

In running water in the Minnesota and Sioux valleys. 
Anacardiace.E. - Sumac Family.

Rilus hirta, (L.) Sndw. Staghorn Sumac.

Rhus typhina, L.

Collected but once in the sonthern part of the Missouri valley, in Charles Mix county.

Rlıus galora, L. Smooth Sumac.

Common on bluffs and banks of streams from the Missouri valley eastward, and in the Black Hills.

Rhus trilobata, Nutt. Skunkbush.

On dry blufts and hills from the Missouri valley westward, common; many specimens have very pubescent leaflets.

Rhus radicanus, I. Poison Oak. Poison Ivy.

In woods and thickets throughout the state.

CELASTRACE王.-Staff-tree Family.

Euonymus atropurpureous, Jacq. Burning Bush. Wahoo.

Occasional in woods in the Sioux valley, and up the Missouri river into Charles Mix county.

Celastrus scandens, L. Bittersweet.

Common in woods and thickets throughout the state.

ACERACEA.-Maple Family.

Mrer saccharinum, L. Silver Maple. Soft Maple.

Acer dasycarpum, Ehrh.

Extends up the Sioux river to Flandreau and up the Missouri river to the western edge of Union county--the southeastern county.

Arel saccharum, Marsh. Sugar Maple. Rock Maple. Acer saccharum, IVang.

Abundant in coulees and ravines, containing a clear spring creek, at the headwaters of the Little Minnesota river. There are some ten coulees extending from one 
to three miles back into the coteaus in which the sugar maple is abundant. Many of the trees are sixty to seventy feet high and eight to ten feet in circumference. As soon as the creek emerges from the hills into the open prairie all the trees except the white elm, box elder and two willows disappear. The coulees are narrow and deep, and the banks are lined with springs which furnisl a constant supply of water. The southernmost coulee in which maples were found is one-half mile south of Sisseton Agency.

Acer Nenumbo, L. Box Elder. Ash-leaved Maple.

Abundant along lakes and streams throughout the state.

BalsaminaCE无.-Jewel-weed Family.

Impatiens biflora, Walt. Spotted Touch-me-not. Impatiens fulva.

In damp woods in the Minnesota and Sioux valleys.

Impatiens anrea, Muhl. Pale Touch-me-not.

Impatiens pallida, Nutt.

In moist woods in the Minnesota valley.

RhamnaCE正, - Buckthorn Family.

Ceanothus velutiuus, Dougl. Velvety Redroot. In the Black Hills near Lead City.

Ceanothus Fendleri, Gray. Fendler's Redroot.

Common in limestone districts in the Black Hills.

$$
\text { VITACE急.-Grape Family. }
$$

Vitis Vulpina, L. Riverside Grape.

Vitis riparia, Michx.

Common along streams and bordering lakes from the Missouri river eastward.

Parthenocissus quinquefolia, (I,) Planch. False Virginia Creeper. Woodbine. 
Ampelopsis quinquefolia, Michx.

Common in same habitat as the last, the Minnesota and Sionx valleys, and in the Black Hills.

Tili,IACEA. - Linden Family.

Tilia Imericana, L. Basswood. American Linden.

Along streans and bordering lakes in the Minnesota and Sioux valleys; up the Missouri valley to Running Water.

$$
\text { MALVACE无.-Mallow Family. }
$$

Malva Sylvestris, L. High Mallow.

Sparingly introduced into waste places in the Sioux valley near Brookings.

Malva rotunditolia, L. Cheese's Runniug Mallow.

A naturalized weed in waste places in the Sioux valley and southern Missouri valley.

Malva verticillata crisua, L. Whorled Mallow.

In waste places in the Sioux valley.

Malvastrum coccineum, (Pursh.) A. Gray. Red Mallow.

Common on dry prairies from the James valley westward.

Abutilon abutilon, (L.) Rusby. Indian Mallow. Abutilon avicenne, Gaertn.

An introduced weed in the southeastern part of the state.

Hibiscus trioumm, I. Venice Mallow. Flower-of-anhour.

In waste places along the Sioux valley in Union county, and up the Missouri valley to Chamberlain, Brule county.

HYPERICACEA\% - St. Johnswort Family.

Iypericum Camadense, L. Canadian St. Johnswort.

In low ground in the Minnesota valley, and in the Black Hills. 
ELATINACEÆ. - Waterwort Family.

Elatinc triandlı, Schk. Long-stemmed Waterwort.

In mud on margins of ponds and rivers in the Minnesota valley; in the Missouri valley in Walworth county, and in White river in the plains region.

CISTACE无.-Rock Rose Family.

Helianthemum majus, (L.) B. S. P. Hoary Frostweed. On roadsides east of Custer in the Black Hills.

VIOLACEA:-Violet Family.

Viola pedatifida, Don. Prairie Violet.

On prairies in the Minnesota, Sioux and James valleys, and in the Black Hills.

Viola obliqua, Hill. Meadow Violet.

IViola cucullata, Ait.

Mostly along streams or in the shady places from the Missouri river eastward, and in the Black Hills.

Viola predata, L. Bird's-foot Violet.

On prairies in the Minnesota valley near Bigstone Lake.

Viola palustıis, L. Marsh Violet.

In moist soil near Sylvan Lake in the Black Hills.

Viola blamcla, Willd. Sweet White Violet.

In dainp ground in the Black Hills.

Viola Nuttallii, Pursh. Nuttall's Violet.

On prairies from the James valley westward throughout the state.

Viola pubescens, Ait. Hairy Yellow Violet.

In rich woods in Union county in the Sioux valley, and in the Black Hills. Most of the specimens referred to this species belong to the next.

Viola scaluriuscula, ('T. \& G.) Scluwein. Smoothish Yellow Violet.

Viola pubescens scabriuscula, T. \& G. 
In rich woods in the Minnesota and Sioux valleys, and in the Black Hills.

Viola Canadensis, L. Canadian Violet.

Abundant in rich woods in the Minnesota and Sionx valleys, and in the Black Hills.

Viola arenaria, Dc. Sand Violet.

In dry soils in the Black Hills, near Rapid City.

Viola camina alluncal, Gray.

In the Black Hills.

$$
\text { LOASACE, E.-Loasa Family. }
$$

Mentzelia oligosperma, Nutt. Few-seeded Mentzelia.

Occasional in the Black Hills; more common in the adjacent plains.

Mentzelia nuda, (Pursh.) T. \& G. Bractless Mentzelia.

A rare plant, reported only for the Black Hills.

Mentzelia clecapetala, (Pursh.) Urban \& Gilg. Showy Mentzelia.

Mentzelia ornata, T. \& G.

Common in dry soils from the Missouri westward.

CACTACE无.-Cactus Fanily.

Opuntia humifusa, Raf. Western Prickly Pear.

Opuntia Rafinesquii, Engelm.

In the Black Hills and the adjacent plains region.

Opuntia fragrilis, (Nutt.) Haw. Brittle Opuntia.

In the Black Hills; rare.

Cactus Missouriensis, (Sweet.) Kuntze. Missouri Cactus. Mamillaria Missouriensis, Sweet.

On bluffs, knolls and plains from the Missouri river westward.

Cactus vivipirus, Nutt. Purple Cactus.

Mamillaria vivipara, Haw.

From the Missouri valley westward. 
ElaeagnaCF, E.-Oleaster Family.

Elaeagnus argentea, Pursh. Silver Berry.

In linestone districts in the Black Hills.

Lepargyrara Canadensis, (L.) Greene. Canadian Buffalo Berry.

Shepherdia Canadensis, Nutt.

Occasional trom the Missouri river to the Black Hills. Lepargriana argentea, (Nutt.) Greene. Buffalo Berry. Shepherdia argentea, Nutt.

Common on bluffs and in thickets from the Missouri valley westward; occasional on bluffs in coulees in the Minnesota valley.

LiYTHRACE王. -Loosestrife Family.

Ammania coccinea, Rottb. Long-leaved Ammannia. In swampy ground from the Missouri valley eastward.

Lythrum alatum, Pursh. Wing-angled Loosestrife.

Occasional in low ground from the Missouri valley eastward.

Onagrace.

Chamanerion angustifolimm, (L.) Scop. Fireweed. Great Willow Herb.

Epilobium angustifolium, L.

In open woods in the Minnesota valley and in the Black Hills.

Epilobium lineare, Muhl. Linear-leaved Willow Herb.

In swamps in the Minnesota and Sioux valleys, and in the Black Hills.

Epilobium paniculatum, Nutt. Panicled Willow Herb.

Occurs in the Dlack Hills.

Epilobium coloratum, Muhl. Purple-leaved Willow Herb.

In low ground in the Minnesota valley. 
Epilobium alenocaulon, Haussk. Northern Willow Herb.

In moist ground throughout the state.

Epilobium Hornemammi, Rerchenb. Hornemann's Willow Herb.

Near Sips Springs in the Black Hills.

Epilobium Drummondii, Kansk. Drummond's Willow Herb.

In the limestone district in the Black Hills.

Onagla biemuis, (L.) Scop. Evening Primrose.

Enothera biennis, L.

Common throughout the state.

Enothera Iaciniata, Hill. Sinuate-leaved Evening Primrose.

Enothera simuata, L.

In the Black Hills; rare.

Anogra albicaulis, (Pursh.) Britton. Prairie Evening Primrose.

Enothera albicaulis, Pursh.

Occasional in low ground throughout the state.

Anogra coronopifolia, (T. \&. G.) Britton. Cut-leaved Evening Primrose.

Enothera coronopifolia, T. \& G.

In the Black Hills and on the adjacent plains.

Anogra pallida leptophylla, (Nutt.)

Enothera pallida leptophylla, (Nutt.) T. \& G.

Enothera leptophylla, Nutt.

Occasional in the Black Hills,

Pachylophus caspitosa, (Nutt.) Raimann. Scapose Primrose.

CEnothera caspitosa, (Nutt.)

In "gumbo soils" from the Missouri valley westward; common.

Meriolix serrulata, (Nutt.) Walp. Tooth-leaved Primrose. 
Cinothera sermlata, Nutt.

In dry soils throughout the state.

Gaura larviflora, Dougl. Small-flowered Gaura.

In dry soil from the Missouri valley westward.

(ianua coccinea, Pursh. Scarlet Gaura.

In dry prairies throughout the state; more common in the James and Missouri valleys.

Gayophyton ramosissimum, T. \& G. Bushy Gayophyton.

On dry knolls in the Black Hills and the adjacent plains.

Circara Lutetiana, L. Enchanter's Nightshade.

In damp woods in the Minnesota valley and the Black Hills.

Circiea alpina, L. Alpine Enchanter's Nightshade.

In moist woods in the Black Hills.

HALORAGIDACEA.-Water Millfoil Family.

Hippuris vulgaris, L. Bottle Brush.

In shallow water in the Sioux valley and locally in the Missouri valley; Faulkton.

Myriophyllum spicatum, L. Spiked Water Millfoil.

Cummon in lakes and slow streams in the Minnesota, Sioux and James valleys.

Myriophyllum verticillatum, L. Whorled Water Millfoil.

In the Minnesota and Sioux valleys; not common.

Myriophyllum heterophyllum, Michx. Various-leaved Water Millfoil.

In slow running water in the Sioux valley; rare.

ARAliace.E.-Ginseng Family.

Aralia racrmosa, L. American Spikenard.

In rich woods in the Minnesota valley. 
Aralia nudicaulis, L. Wild Sarsaparilla.

On shady banks in the Minnesota valley and in the Black Hills.

UMBELLIFER 玉.-Carrot Family, Umbelworts.

Daucus carrota, L. Wild Carrot.

Sparingly naturalized in the Minnnesota and Sioux valleys.

Heracleum lanatum, Michx. Cow Parsnip.

In woods in the Minnesota and Sioux valleys, and in the Black Hills.

Pastinaca sativa, L. Wild Parsnip.

Escaped near Rapid City. in the Black Hills.

Pencedanum nudicaule, (Pursh.) Nutt. White-flowered Parsley.

In dry soil from the Missouri valley eastward, common.

Peucedanum foeniculaceum, Nutt. Fennel-leaved Parsley.

In the James and Missouri valleys and along the White river; not common.

Pencedanum villosum, Nutt. Hairy Parsley.

In dry, clay, soils from the James valley westward; common.

Cymopterus acaulis, (Pursh.) Rydberg. Plain Cymopterus.

Cymopterus glomeratus, Raf.

On dry knolls from the Missouri valley westward.

Cymopterus montamus, T. \& G. Mountain Cymopterus.

In the Black Hills and the adjacent plaius.

Eryugium acpuaticum, L. Button Snakeroot.

In the Sioux valley near Sioux Falls; rare.

Samicula Marylandica, L. Black Snakeroot.

In woods in the Minnesota and Sioux valleys; common. 
Sanicula canadensis, L. Short-styled Snakeroot.

Sanicula Marylandica canadensis, Torr.

In the Minnesota and Sioux valleys and in the Black Hills.

Musineon divaricatum, (Pursh.) Nutt. Leafy Musineon. In "gumbo soils" from the Missouri valley westward; common.

Musineon tennifolimm, Nutt. Scapose Musineon.

In the Black Hills; common.

Musineon trachysperma, Nutt.

Near Hermosa in the Black Hills.

Washingtonia Claytoni, (Michx.) Britton. Wooly Sweet Cicely.

Osmorrhiza brevistylis, DC.

In the Minnesota and the southern part of the Sioux valleys (Union Co.); rare.

Washingtonia longistylis, (Tott.) Britton. Smoother Sweet Cicely.

Osmorrhiza longistylis, Torr.

In rich woods in the Minnesota and Sioux valleys and in the Black Hills.

Washingtonia muda, (Torr.) Western Sweet Cicely. Osmorrhiza muda, Torr.

In the Black Hills, not common.

Sium cicutafolium, Gmel. Hemlock Water Parsnip.

In swamps from the Missouri valley eastward.

Zizia aurea, (L.) Koch. Golden Meadow Parsuip.

Abundant in low prairies from the Missouri valley eastward.

Zizia cordata, (Wa1t.) DC. Heart-leaved Alexander.

On low prairies in the Minnesota and Sioux valleys and in the Black Hills. Less common than the last. 
Carum calıui, L. Caraway.

Sparingly introduced in the Sioux valley and in the Black Hills.

Carum (iairdneli, (Nutt.) Benth. \& Hook. Gairdner's Caraway.

Reported by Dr. Gray for the Black Hills.

Cicuta maculata, L. Water Hemlock.

In swamps and streams from the Missouri valley eastward, and in the Black Hills.

Cicuta bulbifela, L. Bulb-bearing Water Hemlock.

In a cold spring swamp near Elkton in the extreme eastern part of the Sioux valley.

Deringia canadensis, (L,) Kuntze. Honewort.

Cryptotania canadensis, L.

In rich woods in the Minnesota and Sioux valleys.

Berula erecta, (Huds.) Coville. Cut-leaved Water Parsnip.

Berula augustifolia, Mert. \& Kock.

In swamps in the Minnesota valley and in the Black Hills.

Bupleurum rotundifolium, L. Modesty.

Introduced into the Sioux valley in grass seed.

CORnACE正.-Dogwood Family.

Cornus canadensis, I. Dwarf Cornel.

In damp woods in the Black Hills.

Colnus Baileyi, Coult. \& Evans. Bailey's Dogwood.

In the Black Hills.

Cornus asperifolia, Michx. Rough-leaved Dogwood.

Along the Missouri river and in the southern part of the state, Union, Clay and Yankton counties.

Cornus stolonifera, Michx. Red Osier.

In thickets along streams and bordering lakes throughout the state. 
Cornus amonum, Mill. Silky Cornel.

Cormus sericea, L.

Along the Missouri river in Yankton and Charles Mix counties.

\section{Pyrol,ACE, - Wintergreen Fanily.}

Pyrola rotundifolia, L. Round-leaved Wintergreen.

In woods in the Black Hills, Lead City.

Pyrola Elliptica, Nutt. Shin-leaf.

On shady hillsides in the Black Hills.

Pyrola chlorantha, Sw. Greenish-flowered Wintergreen.

In woods in the Black Hills.

Pyrola secunda, L. One-sided Wintergreen.

In deep shady ravines in the Minnesota valley and in the Black Hills.

Pyrola rotundifolia bracteata, (Nutt.) Gray.

In a cold bog near Sylvan lake in the Black Hills.

Monotropace死-Indian Pipe Family.

Pterospora andromedea, Nutt. Pine Drops.

In woods in the Black Hills; Custer and Rapid City.

Monotropa uniflora, L. Indian Pipe.

In deep, wooded ravines in the Minnesota valley; Roberts county.

ERICACE正.-Heath Family.

Arctostaphylos uva-ursi, Spreng. Red Bearberry.

On dry knolls in the Black Hills, and in the adjacent plains; Custer, and the Bad Lands.

VACCINEACE, 两,---Huckleberry Family.

Vaccinium myrtillus microphyllum, Hook. Bilberry, Whortleberry.

In the Black Hills. 
Primutacele.-Primrose Fanily.

Androsace oceidentalis, Pursh. Androsace.

In dry soils from the Missouri valley eastward; common.

Audrosace septentrionalis, L. Mountain Androsace.

In the Black Hills, Custer.

Androsace septentrionalis subulifera, Gray.

In the footliills of the Black Hills; near Rapid City.

Steironema ciliamm, (L.) Raf. Fringed Loosestrife.

Lysimachia ciliata, L.

In damp thickets from the Missouri valley eastward, and in the Black Hills; common.

Nammbergia thrysiflora, (L.) Duby. Tufted Loosestrife. Lysimachia thyrsiflora, L.

In cold spring bogs in the Minnesota valley near Elkton in the Sioux valley, and in the Black Hills.

Centunculus minimus, L. Chaffweed.

In the upper Missouri valley, (Walworth and Potter counties) and the Black Hills.

Dodecatheon media, L. Shooting Star, American Cowslip.

On moist banks in the Black Hills; Rapid City, and Custer.

\section{OLEACEAE.-Olive Family.}

Fraxinus lanceolata, Borck. Green Ash.

Fraximus viridus, Michx. F.

Abundant along streams and bordering lakes throughout the state.

Fraxinus Pennsylvanicus, Marsh. Red Ash.

Fraximus pubescens, Lam.

With the last throughout the state and rather more common. 
Fraxinus Ancricana, L. White Aslr.

This lias been repeatedly reported for this state, but the most authentic account of it in the state is the following from Prof. Williams' note book: "Twigs sent by Mr. Jones from Sioux Falls to Dr. 'Trelease were pronounced to be this species." If it occurs in the Minnesota or Sioux regions it is exceedingly rare, as for two summers special effort has been made to detect it.

\section{GentianaCE死.-Gentian Family.}

Gentiani detonsa, Rottb. Fringed Gentian.

Gentiana serrata, Gunner.

In cold spring bogs in the Minnesota valley; one station in the Sioux valley; Elkton.

Gentiana acuta, Michx. Northern Gentian.

Gentiana amarella acuta, Herder.

Near Custer in the Black Hills.

Gentiana puberula, Miclix. Downy Gentian.

Common on prairies in the Minnesota and Sioux valleys.

Gentiana Andrewsii, Griseb. Closed Gentian.

In low places in the Minnesota and Sioux valleys; commou.

Frasera speciosa, Dougl. Showy Frasera.

On dry, barren knolls in the Black Hills.

Tetragonanthus deflexus, (J. E. Smith.) Kuntze. Spurred Gentian.

Swertia deflexa, J. E. Smith.

In woods in the Black Hills.

MenyanthaCE无.-Buckbean Family.

Menyantlıes trifoliata, L. Buckbean. Bogbean.

In a cold spring bog near Elkton in the Sioux valley. 
APOCINACE E.-Dogbane Family.

Apocymum androsiemifolium, L. Spreading Dogbane. In thickets in the Minnesota and Sioux valleys and in the Black Hills.

Apocyumm cammabinum, L. Indian Hemp.

On dry banks from the Missouri valley eastward.

ASCLEPIADACE无.-Milkweed Family.

Asclepias tuberosi, L. Pleurisy Root. Butterfly Weed. In thickets in the southern part of the Sioux valley; Union county.

Asclepias incarnata, L. Swamp Milkweed.

In swamps from the Missouri valley eastward.

Asclepias syriaca, L. Common Milkweed. Asclepias Cormuti, Dec.

On prairies and in thickets in the Minnesota and Sioux valleys.

Asclepias spcciosa, Torr. Showy Milkweed.

In low ground in the Minnesota and Sioux valleys.

Asclepias ovalifolia, Dec. Oval-leaved Milkweed.

On prairies in the Minnesota and Sioux valleys, and in the Black Hills; rare.

Ascrepias verticillata, L. Whorled Milkweed.

Common on banks and prairies from the Missouri valley eastward.

Asclepias pumila, (Gray.) Vail. Low Milkweed. Asclepias verticillata pumila, Gray.

Common on the dry plains from the Missouri valley westward, seems to replace the last.

Arerates viridiflora, (Raf.) Eaton. Green Milkweed.

Occasional in sandy soils throughout the state.

Arerates angustifolia, (Nutt.) Dec. Narrow-leaved Milkweed.

In the Black Hills and the adjacent plains. 
Acerates lanuginosa, (Nutt.) Dec. Woolly Milkweed.

On prairies in the Sioux valley; rare.

Convolvulace巵.-Morning Glory Family.

Evolvulus pilosus, Nutt. Evolvulus. In dry plains west of the Missouri river and in the Black Hills.

Quamoclit coceinea hederifolia. Small Red Morning Glory.

Introduced in gardens near Brookings.

Ipomoea leptophylla, Torr. Bush Morning Glory.

In dry soils from the Missonri river to the Black Hills.

Ipommea hederaceae, Jacq. Ivy-leaved Morning Glory.

A bad weed in fields in the Sioux valley near Brookings.

Convolvulus sepium, L. Hedge Bindweed.

In thickets from the Missouri valley eastward and in the Black Hills.

Convolvulus repens, L. Trailing Bindweed.

In cultivated and waste fields from the Missouri valley eastward.

Cuscutace. -Dodder Family.

Cuscuta Epithymum, Murr. Clover Dodder.

On alfalfa in the Sioux valley in Brookings and Clark counties, and in the Black Hills. An introduced parasite, doing considerable damage to alfalfa wherever it occurs in quantity.

Cuscuta arvensis, Beyrich. Field Dodder.

On various large herbs in the Minnesota valley and in the Black Hills.

Cuscuta coryli, Engelm. Hazel Dodder.

Cuscuta inflexa, Engelin.

On large herbs throughout the state.

Cuscuta Gronovii, Willd. Gronovi's Dodder.

In the Sioux and Minnesota valleys; common. 
Cuscuta paradoxi, Raf. Glomerata Dodder.

Cuscuta glomerata, Choisy.

On composites in the Minnesota and Sioux valleys.

POLEMONIACE瓜.-Plilox Family.

Phlox pilosi, L. Downy Phlox.

On prairies in the Minnesota and Sioux valleys.

Phlox Kelseyii, Britton. Kelsey's Phlox.

In the Black Hills.

Plulox Douglassii, Hook. Douglass' Phlox.

Common in the Black Hills.

Phlox Douglassii andicola, Britton.

On dry table-lands in the Black Hills.

(tilia spicata capitata, Gray. Capitate Gilia.

On dry knolls in the Black Hills.

Collomia linearis, Nutt. Narrow-leaved Collomia.

Gilia linearis, Gray.

On dry soils from the Missouri valley westward; found also in one station in the Sioux valley.

HYDROPHYLLACE.E.-Waterleaf Family.

Hydrophyllum Virginicum, L. Virginian Waterleaf.

Common in woods in the Minnesota valley; occasional in the Sioux valley.

Maceocalyx Nyctalea, (L.) Kuntze. Nyctalea. Ellisia nyctalea, L.

Common in shady, moist ground in the Minnesota valley; less common in the Sioux, James and Missouri valleys and in the Black Hills.

$$
\text { BORAGINACE, } \text { : - Borage Family. }
$$

Heliotropium Curassanicum, L. Seaside Heliotrope.

In saline soils in the Jannes valley in Faulk and Beadle counties. 
Lalpula lappula, (L.) Karst. Burrseed. European Stickseed.

Echinospermum lappula, Lehm.

Sparingly introduced in the Sioux valley.

Lappula redowskii occidentalis, (Wats.) Rydberg.

Western Stickseed.

Common from the Missouri river westward.

Lappula Virginiana, (L.) Greene. Virginian Stickseed. Echinospermum Virginicum, L.

In dry woods in the Minnesota valley and the Black Hills; rare.

Lappula floribunda, (Lehm.) Greene. Large-flowered Stickseed.

Echinospermum floribunda, Lehm.

In the Black Hills.

Lappula Ameriøana, (Gray.) Rydberg. Nodding Stickseed.

Echinospermum deflexum Americanum, Gray.

In the Black Hills; rare.

Allocarya scopulorum, Greene. Mountain Allocarya.

In the southern Missouri valley; Charles Mix county.

Cryptanthe Pattersonii, (Gray.) Greene. Patterson's Cryptanthe.

Krynitzkia Pattersonii, Gray.

In the Black Hills; Custer and Lead City.

croptanthe crassisepala, (T. \& G.) Greene. Thicksepaled Cype.

Krynitzkia crassisepala, Gray.

In the Bad Lands, east of the Black Hills.

Oreocarya glomerata, (Pursh.) Greene. Clustered Oreocarya.

Krynitzkia glomerata, Gray.

In dry soils from the Minnesota valley westward. 
Mertensia panienlata, (Ait.) Don. Tall Lungwort.

Iu the Black Hills; Rockford.

Mretensia lanceolata, (Pursh.) DC. Lance-leaved Lungwort.

Common in thickets and on plains from the Missouri valley westward.

Mertensia sibrricus, (L.) Don. Siberian Lungwort.

Dr. Rydberg says: "A single fruiting specimen which seems to belong to this species was collected at Rockford.

Myosot is macrosperma, Engelm. 'Large-seeded Forgetme-not.

Near Hot Springs in the Black Hills; rare.

Myosotis sylvatical, Hoffm. Sylvan Forget-me-not.

In damp, rich places in the high parts of the Black Hills.

Lithospermum (anescens, (Michx.) Lehm. Hoary Puccoon.

Common on prairies and in the edge of thickets from the James valley eastward.

Lithospermum angustifolimm, Michx. Narrow-leaved Puccoon.

Common on prairies thruughout the state.

Onosmodium Molle, Michx. Soft-hairy False Cromwell. In prairies throughout the state; prefers sandy soil.

Erohium vulgare, L. Viper's Bugloss.

Sparingly naturalized in the Sioux valley; Brookings.

$$
\text { VERBENACE, - Vetvain Family. }
$$

Verbena urticafolia, L. White Vervain.

In thickets in the Minnesota and Sioux valleys, and the southern part of the Missouri valley; Charles Mix county. 
Verbena hastata, L. Blue V'ervain.

in thickets and moist places from the Missouri valley eastward, and in the Black Hills.

Verbena stricta, Vent. Hoary Vervain.

In moist or dry soil throughout the state.

Verbena bracteosil, Michx. Large-bracted Vervain.

On prairies throughout the state; rare east of the Missouri valley; more common westward.

Verbena bipinnatificla, Nutt.

On dry soil from the Missouri valley westward.

Lippia cuneifolia, (Tott.) Steud. Fogfruit.

Occasional in the James and Missouri valleys.

LABIATE. - Mint Family.

Teucrium Canadensis, I. Wood Sage. Germander.

In moist soil in the Sioux valley.

Teucrimm occidentale, Gray. Hairy Germander.

In thickets in the Minnesota, Sioux and James valleys.

Scrutellaria lateriflora, L. Mad-dog Skull Cap.

In low, shady places from the Missouri valley eastward.

Scutellaria parvula, Michx. Small Skull Cap.

On low prairies in the Minnesota, Sicux, Jannes and Missouri valleys.

Scutellaria galericulata, L. Marsh Skull Cap.

In damp ground from the Missouri valley eastward, and in the Black Hills.

Agastache nepetoides, (L.) Kuntze. Catnip. Giant Hyssop.

Lophanthus nepetoides, Beuth.

In the Minnesota valley and the sonthern part of the Sioux valley, at Sioux Falls; Union county. Sone of the specimens from the Minnesota valley agree with A. schrophularicefolia in the pubescence of the leaves 
and stem, but have the small greenish yellow corolla of A. nepetoides.

Agastaclie anctloidola, (Nutt.) Britton. Fragrant Giant Hyssop.

Lophanthus anisatus, Benth.

In thickets from the Missouri valley eastward and in the Black Hills.

Nepeta cataria, L. Catnip.

Sparingly introduced in the Minnesota and Sioux valleys.

Dracocephalum parvifloxum, Nutt. American Dragonhead.

In dry soils in the Sioux valley near Dell Rapids, and in the Black Hills.

Prunella vulgaris, L. Selfheal.

In damp woods in the Black Hills.

Pluysostegia Vilginiana, (L.) Benth. False Dragonhead.

In the Minnesota, Sioux and James valleys.

Leonurus cardiaca, L. Motherwort.

Naturalized in the Sioux valley near Sioux Falls.

Stachys palustris, L. Hedge Nettle.

In the Minnesota and Sioux valleys, and in the Black Hills.

Stachys aspera, Michx. Rough Hedge Nettle.

Near Custer in the Black Hills.

Salvia lanceolata, Willd. Lance-leaved Sage.

On the dry plains from the Missouri valley westward.

Monarla fistulosi, L. Wild Bergamont.

Common in thickets from the Missouri valley eastward, and in the Black Hills.

Monarda scabla, Beck. Pale Wild Bergamont.

Monarda fistulosa Mollis, Benth.

On prairies and plains in the Minnesota valley and westward to the Black Hills. 
Hedeona hispida, Pursh. Rough Pennyroyal.

Common on dry prairies throughout the state.

Hedeomil Drummondii, Benth. Drummond's Pennyroyal.

In dry soils in the Black Hills, and in the adjacent plains.

Hyssopus officinalis, L. Hyssop.

Sparingly naturalized in the Sioux valley near Brookings.

Lycopus rubellus, Moench. Stalked Water Hoarhound. In wet ground in the Minnesota and Sioux valleys.

Lycopus Americanus, Muhl. Cut-leaved Water Hoarhound.

Lycopus simuatus, Ell.

Common in wet soils throughout the state.

Lyсорus lucidus, Turcz. Western Water Hoarhound.

In swamps and bogs in the Minnesota and Sioux valleys.

Mentha Canadensis, L. American Wild Mint.

Common in moist soils throughout the state.

SOLANACE正.-Potato Family.

Physalis longifolia, Nutt. Long-leaved Ground Clierry.

In the Sioux and Missouri valleys and the Black Hills; more common westward.

Pliysalis lanceolata, Michx. Prairie Ground Cherry.

On dry prairies throughout the state.

Physalis Virginiana, Mill. Virginian Ground Cherry.

In thickets in the Minnesota and Sioux valleys, and in the Black Hills.

Physalis hoterophylla, Nees. Clanmy Ground Cherry.

In the Minnesota and sonthern Missouri valleys, and in the Black Hills. 
PIysalis lotundata, Rydb. Round-leaved Ground Cherry.

In the foothills of the Black Hills, and the adjacent plains.

Solanum nigrum, L. Black Nightshade.

In the waste places from the Missouri valley eastward and in the Black Hills.

Solanum triflormm; Nutt. Cut-leaved Nightshade.

In waste places in the Minnesota and Sioux valleys, and in the Black Hills.

Solaumm rostratum, Dunal. Texas Thistle. Beaked Nightshade.

On dry prairies and in waste places throughout the state. From the Missouri valley eastward it is found in waste places, apparently introduced from the west. On the plains west of the Missouri river it is more abundant and apparently native.

Schrophulariacex. - Figwort Family.

Verbascum thapsus, L. Mullen.

Introduced into the southeastern part of the state, and in the Black Hills; rare.

Linaria linaria, (L.) Karst. Butter-and-eggs, Yellow Toad Flax.

Linaria vulgaris, Mill.

Sparingly naturalized in the Sioux valley.

Linaria Canadensis, (L.) Dumont. Blue Toad Flax.

In dry soils in the Black Hills.

Schrophularia Marylandica, L. Heal-all. Maryland Figwort.

Schrophularia nodosa Marylandica, Gray.

In thickets from the Missouri valley eastward, and in the Black Hills.

Pentstemon cristatus, Nutt. Crested Beard-tongue.

On dry bluffs in the Missouri valley and in the Black Hills. 
Pentstemon albidus, Nutt. White Beard-tongue.

On prairies from the Missouri valley eastward, and in the Black Hills.

Pentstemon gracilis, Nutt. Slender Beard-tongue.

Common on prairies from the Missouri valley eastward, and in the Black Hills.

Pentstenon grandiforus, Nutt. Large Flowered Beard tongue.

On dry knolls and banks of ravines throughout the state.

Pentstemon glaber, Pursh. Smooth Beard-tongue.

On low prairies from the Missouri valley westward.

Pentstemon angustifolius, Pursh. Pale Beard-tongue.

Near Hot Springs in the Black Hills, rare.

Pentstemon Jamesii, Benth. James' Beard-tongue.

On table-lands near Hot Springs in the Black Hills.

Collinsia parviflora, Dougl. Small-flowered Collinsia.

On dry hill sides in the Black Hills.

Mimulus ringens, L. Monkey Flower.

Along streams in the Minnesota and Sioux valleys.

Mimulus Jamesii, T. \& G. James' Monkey Flower.

In bogs and swamps in the Minnesota valley and in the Black Hills.

Mimulus luteus, L. Yellow Monkey Flower.

In damp, shady ground in the Black Hills near Lead City.

Momniera rotumbitolia, Michx. Round-leaved Hedge Hyssop.

Herpestris rotundifolia, Pursh.

In shallow pools and on muddy shores from the Missouri valley eastward, and in the Black Hills.

Ilysanthes eratioloides, (L.) Benth. False Pempernel.

Ilysanthes riparia, Raf:

On muddy shores from the Missouri valley eastward. 
Wulfenia lubra, (Hook.) Greene. Western Wulfena.

Synthris mbra, Benth.

On hill sides near Custer in the Black Hills.

Veronica Anagallis-aquatica, L. Water Speedwell.

In brooks from the Missouri valley eastward and in the Black Hills.

Veronica Americana, Schwein. Anerican Brooklime.

In cold swamps in the Minnesota valley and in the Black Hills.

Veronica peregrina, L. Neckweed.

In low ground from the Missouri valley eastward and in the Black Hills.

Veronica officinalis, L. Common Speedwell.

Sparingly introduced in the Sioux valley.

Leptandra Virginica, (L.) Nutt. Culver's Root.

Veronica Virginica, L.

On prairies in the Minnesota and Sioux valleys; rare.

Gerardia Besseyaua, Britton. Bessey's Gerardia.

Gerardia temiflora macrophylla, Benth.

On low prairies from the Missouri valley eastward.

Gerarlia aspera, Dougl. Rough Gerardia.

On prairies from the Missouri valley eastward; common.

Castilleja acuminata, (Pursl.) Spreng. Painted Cup.

In woods in the Black Hills.

Castilleja sessiflora, Pursh. Prairie Painted Cup.

On dry bluffs and sandy knolls throughout the state; much more common from the Missouri valley westward.

Orthocarpus luteus, Nutt. Yellow Orthocarpus.

Occasional in dry, sandy soils throughout the state.

Pedicularis lanceolata, Michx. Swamp Lousewort.

In swamps and low prairies in the Minnesota and Sioux valleys. 
Pedicularis Canadensis, L. Wood Betany. Lousewort. In thickets in the Minnesota and Sioux valleys.

LENTIBULARIACEA - Bladdderwort Family.

Ctricularia vulgaris, L. Greater Bladderwort.

In clear water ponds and slow streams from the Missouri valley eastward.

OROBANCHACEA.-Broomrape Family.

Thalesia fasiculata, (Nutt.) Britton. Yellow Cancer Root. Aphyllon fasiculatum, Gray.

In the Missouri valley and the Black Hills; rare.

Orobanche ludoviciana, Nutt. Louisiana Broomrape.

From the Missouri valley eastward and in the Black Hills.

PhrymaCe无.-Lopseed Family.

Plixyma leplostachya, L. Lopseed.

Iis woops and thickets throughout the state.

PlantaginaCE正.--Plantain Family.

Plantago major, L. Common Plantain.

Introduced into waste places throughout the state.

Plantago Rugelli, Dec. Rugel's Plantain.

Introduced into waste fields in the Sioux valley.

Plantago lanceolata, L. Ribwort.

Sparingly introduced into waste places in the Sioux valley.

Plantago eriopoda, Torr. Saline Plantain.

In low alkaline places in the Minnesota and Sioux valley.

Plantago Purshii, R. \& S. Pursh's Plantain.

Plantago patagonica gnaphalioides, Gray.

Common on dry plains from the Missouri valley westward. 
Plantago aristata, Michx. Large-bracted Plantain.

Plantago patagonica aristata, A. Gray.

On the dry plains from the Missouri valley westward; not common.

Plantago elongata, Pursh. Slender Plantain.

Plantrgo pusilla, Nutt.

On low damp prairies in the southern Missouri valley, Aurora and Charles Mix counties.

RUBIACE无. - Nadder Family.

Galium Aparine, L. Cleaver. Goosegrass.

In woods and thickets in the Minnesota and Sioux valleys and in the Black Hills.

Galium boreale, L. Northern Bedstraw.

In thickets and on banks from the Missouri va!ley eastward and in the Black Hills.

Galium triflorum, Michx. Fragrant Bedstraw.

In woods and thickets in the Minnesota and Sioux valleys and in the Black Hills; also extends up the Missouri valley into Charles Mix county.

Galium trifidum, L. Small Cleavers.

In spring swamps in the Minnesota and Sioux valleys.

Galium tinctorum, L. Wild Madder.

In low thickets in the Sioux valley.

CAPRIFOLIACEE.-Honeysuckle Family.

Sambucus racemosus, L. Racemed Elder.

In canons in the Black Hills.

Sambucus canadensis, L. Sweet Elder.

In moist soil near Rapid City in the Black Hills.

Viburnum opulus, L. Cranberry Tree.

In damp ravines in the Minnesota valley (rare) and in the Black Hills. 


\section{96}

Viburnum Lentago, L. Sweet Viburnum.

Common on wooded banks in the Minnesota valley and in the Black Hills; occurs also near Sioux Falls in the Sioux valley.

Linnaea borealis, I. Twinflower.

In woods in the Black Hills.

Symploricarpus racemosus, Michx. Snowberry.

In thickets along streams and on dry banks throughout the state.

Symphoricarpus pauciflorus, (Robbins) Britton. Low Snowberry.

Symphoricarpus racemosus pauciflorus. Robbins.

On rich wooded bluffs in the Minnesota valley and in the Black Hills.

Symphoricarpus occidentalis, Hook. Wolf Berry.

Occasional in thickets in the Minnesota and Sioux valleys.

Symphoricarpus Symphoricarpus, (L.) MacM. Coral Berry.

Symphoricarpus vulgaris, Michx.

On dry banks from the Missouri valley eastward.

Lonicera glaucescens, Rydberg. Douglas' Honeysuckle.

Common in woods and ravines in the Minnesota valley, in the Sioux valley near Sioux Falls and in the Black Hills.

Adoxacex.-Moscliatel Family.

Arloxa moschatellina, L. Moschatel. Muskroot.

In the limestone region in the Black Hills.

VALERIANACEE.-Valerian Family.

Valeriana edulis, Nutt. Tobacco Root.

In damp soil near Rockford in the Black Hills. 
Valeriana sylvatica, Banks. Wood Valerian.

In moist soils in the Black Hills.

Cucurbitace F.-Gourd Family.

Micrampelis lobata, (Michx.) Greene. Wild Balsam Apple.

Echinocystis lobata, T. \& G.

In thickets along streams from the Missouri valley eastward.

Sicyos angulatus, L. Burr Cucumber.

In thickets along streams in the southern part of the state, east of the Missouri river; Yankton; Elk Point, and Brookings.

Campanulace..-Bellwort Family.

Campanula rotundifolia, L. Harebell.

On moist rocks in the Black Hills.

Campanula aparimoides, Pursh. Marsh Bellwort.

In wet ground in the Black Hills.

Campanula Americana, L. Tall Bellflower.

In thickets in the Missouri valley from Yankton southward and up the Sioux valley to Sioux Falls.

Legouzia perfoliata, (L.) Britton. Venus Looking-glass. Specularia perfoliata, A. DC.

In the southern Missouri valley (Charles Mix county), and in the Black Hills.

Lobelia syphilitica, L. Blue Cardinal Flower.

Common in low moist ground in the Minnesota and Sioux valleys and in the Black Hills.

Lobelia spicata hiltella, Gray. Prairie Lobelia.

Common on low praires from the Missouri valley eastward.

Lobelia Kalmii, L. Brook Lobelia.

In cold spring bogs in ravines in the Minnesota valley. 
Cichoriaces.-Chicory Family.

Tragopogon pratensis, L. Meadow Salsify.

Naturalized in the Minnesota and Sioux valleys.

Taraxacum Taraxacum, (L.) Karst. Dandelion.

In lawns and and waste fields from the James valley eastward and in the Black Hills.

Sonchus asper, (L.) All. Spiny Sow Thistle.

In waste places from the Minnesota valley eastward and in the Black Hills.

Lactuca Scariola, L. Prickly Lettuce.

In fields and waste places from the Missouri valley eastward; not abundant.

Lactuca Ludoviciana, (Nutt.) DC. Western Lettuce.

Common on shady bauks from the Missouri valley eastward and in the Black Hills.

Lactuca Canalensis, L. Tall Lettuce.

In most thickets in the Sioux and James valleys.

Lactuca pulchella, (Pursh.) DC. Large-flowered Blue Lettuce.

In low places from the Missouri valley eastward and in the Black Hills.

Lactuca spicata, (Lam.) Hitch. Tall Blue Lettuce.

Lactuca leucophcea, Gray.

In moist thickets in the Minnesota and Sioux valleys.

Lygodesmia juncea, (Pursh.) D. Don. Rush-like Lygodesmia.

Common on breaking from the Missouri valley eastward and on dry plains from the Missouri valley westward.

Agoseris glauca, (Pursh.) Greene. Large-flowered Agoseris.

Troximon glaucum, Pursh.

On prairies and plains throughout the state. 
Agoseris parviflora, (Nutt.) Greene. Small-flowered Agoseris.

Troximon glaucum parviflorum, Gray.

In the Black Hills and the adjoining plains.

Agoseris scorsonerafolia, (Schrad.) Greene. Western Agoseris.

On railroad embankments near Custer, Black Hills.

Nothocalai cuspidata, (Pursh.) Greene. False Calais. Troximon cuspidatum, Pursh.

On prairies from the Missouri valley eastward.

Crepis runcinata, (James.) T. \& G. Naked Stemmed Hawksbeard.

In low moist soils in the Minnesota and Sioux valleys and in the Black Hills.

Hielacium umbellatum, L. Narrow-leaved Hawkweed. In damp ground in the Minnesota valley and in the Black Hills.

Hieracium Camadense, Michx. Canada Hawkweed.

On shady banks in the Minnesota valley and in the Black Hills.

Hieracium Fencleri, Schut. Fendler's Hawkweed.

On dry liills wear Rockford in the Black Hills.

Nabalus albus, (L.) Hook. Rattlesnake Root. Prenanthes alba, L.

In rich woods in the Minnesota valley.

Nabalus asper, (Michx.) T. \& G. Rough White Lettuce. Prenanthes asper, Michx.

On low prairies in the Minnesota, Sioux, James, and southern Missouri valleys and the Black Hills.

Nabalus racemosus, (Michx.) DC. Glaucous White Lettuce.

Prenanthes racemosa, Michx.

On low prairies in the Minnesota and Sioux valleys and in the Black Hills. 
Ambrosiace.⿻一丿工厶.-Ragweed Family.

Iva axillaris, Pursh. Small-flowered Marsh Elder.

In dry alkaline soils from the Missouri valley westward.

Iva xanthiifolia, (Tresen.) Nutt. Burweed. Marsh Elder.

In waste places from the Missouri valley eastward and in the Black Hills.

Ambrosia triflda, L. Great Ragweed. Bitterweed.

In thickets and waste places from the Missouri valley eastward.

Ambrosia trifida integrifolia, (Muhl.) T. \& G.

With the type, common.

Ambrosia artemisiaefolia, L. Ragweed.

Abundant in waste places along roads and in cultivated field from the Missouri valley eastward, rare in the Black Hills.

Ambrosia psilostachya, DC. Western Ragweed.

In light soils throughout the state; more common from the Missouri valley westward.

Gaertneria discolor, (Nutt.) Kuntze. White-leaved Gaertneria.

Franseria discolor, Nutt.

In dry soils in the Black Hills and the adjoining plains.

Xanthium Canadense, Mill. American Cocklebur.

On loose, sandy soils bordering streams and lakes from the Missouri valley eastward.

Composites.-Thistle Family.

Veruonia fasciculata, Michx. Western Iron Weed.

Common in low places from the Missouri valley eastward.

Eupatorium maculatum, L. Spotted Joe-Pye Weed.

In swampy ground in the Minnesota and Sioux valleys and the Black Hills. 
Eupatorium maculatum amoenum, (Pursh.) Britton. In low ground in the Minnesota and Sioux valleys. Quite distinct from the type.

Eupatorium altissinum, L. Tall Thoroughwort.

In dry soils, near timber, in the James, Sioux and Minnesota valleys and the Black Hills.

Eupatorium perfoliatum, L. Boneset.

In swamps in the Minnesota valley, in the eastern part of the Sioux valley and in the Missouri valley near Running Water.

Eupatorium ageratoides, L. F. White Snakeroot.

On wooded bluffs in the Minnesota, Sioux, and southern James valleys, and extending up the Missouri valley to Charles Mix county.

Kulnia glutinosa, Ell. Prairie False Boneset.

Kuhnia eupatorivides corymbulosa, T. \& G.

On prairies throughout the state, but rare west of the Missouri river.

Lacinaria squarrosa, (L.) Hill. Colicroot.

Liatris squarrosa, Willd.

In the southern Missouri valley; Yankton, Running Water and Charles Mix county.

Lacinaria punctata, (Hook.) Kuntze. Dotted Button Snakeroot.

Liatris punctata, Hook.

On prairies and plains throughout the state, very common. A form with creamy white flowers is found.

Lacinaria scariosa, (L.) Hill. Large Button Snakeroot. Blazing Star.

Liatris scariosa, Willd.

From the Missouri valley eastward and in the Black Hills; common.

Lacinaria spicata, (L.) Kuntze. Dense Button Snakeroot. Devil's Bit. 
Liatris spicata, I.

In low prairies in the Minnesota and Sioux valleys.

Gutienezia Sarothra, (Pursh.) Britt. \& Rusby. Gutierrezia.

Gutierrezia Euthamice, T. \& G.

On the dry plains from the Missouri valley westward.

Grindelia s(fuarlosa, (Pursh.) Dunal. Broad-leaved Gum Plant.

In dry soil throughout the state. It is becoming a weed in waste places in the eastern part of the state.

Chrysopsis villosa, (Pursh.) Nutt. Hairy Golden Aster.

Common in dry soil from the Missouri valley eastward and in the Black Hills. Many of the western forms are very close to $C$. hispida.

Chrysothammus Douglasii, (Gray.) Douglas's Rayless Goldenrod.

Bigelovia Douglasii, Gray.

In dry alkaline soils from the Missouri valley westward to the Black Hills.

Eriocarpum grimdelioides, Nutt. Rayless Eriocarpum.

In dry soils in the Black Hills and the surrounding plains.

Eriocappum spinulosum, (Nutt.) Greene. Cut-leaved Eriocarpum.

Aplopappus spinulosus.

In dry soils throughout the state; but rare in the Minnesota and Sioux valleys, common westward.

Solidago flexicaulis, L. Broad-leaved Goldenrod.

Solidago latifolia, L.

On shady banks in the Minnesota valley.

solidano electa, Pursh. Slender Goldenrod.

On dry knolls in the Black Hills. 
Solidago r’igidiuscula, (T. \& G.) Porter. Slender Showy Goldenrod.

Solidago speciosa rigidiuscula, T. \& G.

In dry soils in the Missouri and Sioux valleys. Rare.

Solidago arguta, Ait. Cut-leaved Goldenrod.

In rich woods in the Minnesota and Sioux valleys.

Solidago rupestris, Raf. Rock Goldenrod.

Occasional on rocky banks in the Minnesota and Sioux valleys and in the Black Hills.

Solidago serotina, Ait. Late Goldenrod.

In thickets and low places throughout the state except the Black Hills.

Solidago Missonriensis, Nutt. Missouri Goldenrod.

On prairies throughout the state.

Solidago Canadensis, L. Canada Goldenrod.

From the Missouri valley eastward and in the Black Hills; common in thickets and on low prairies.

Solidago Canadensis procera, (Ait.) 'T. \& G.

Range the same as the type.

Solidago Canarlensis gilvos canescens, Rydberg.

In dry soil in the Minnesota valley.

Solidago nemoralis, Ait. Field Goldenrod. Dyers Weed.

On dry banks and hills throughout the state.

Solidago Radula, Nutt. Western Rough Goldenrod.

In dry soils throughout the state.

Solidago rigida, L. Hard-leaved Goldenrod.

On prairies throughout the state. The most abundant of all the species.

Eutlamia graminifolia, (L.) Nutt. Fragrant Goldenrod. Solidago lanceolata, L.

In moist soils in the Minnesota, Sioux, and James valleys and in the Black Hills. 
Euthamia Caroliniana, (L.) Greene. Slender Fragrant Goldenrod.

Solidago tenuifolia, Pursh.

A single specimen of the species was collected in the Black Hills by Mr. Carter in 1897.

Boltonia asteroides, $\left(\mathrm{L}_{\text {. }}\right) \mathrm{L}$ 'Her. Aster-like Boltonia.

In low moist soils from the Missouri valley eastward.

Aster Lindleyanus, T. \& G. Lindley's Aster.

In low ground in the Minnesota valley.

Aster sagittifolius, Willd. Arrow-leaved Aster.

In dry soils in the Minnesota valley.

Aster Nova-Anglia, L. New England Aster.

In thickets in the Minnesota, Sioux, and James valleys.

Aster oblongifolius, Nutt. Aromatic Aster.

In dry soils from the Missouri valley eastward; the plant is most abundant on dry gravelly hillsides.

Aster laevis, L. Smooth Aster.

On sandy banks of streams from the Missouri valley eastward and in the Black Hills.

Aster patulus, Lam. Spreading Aster.

In the Black Hills near Custer.

Aster junceus, Ait. Rush Aster.

In cold spring bogs in the Minnesota valley, in the extreme eastern part of the Sioux valley and in the Black Hills.

Aster sericeus, Vent. Western Silky Aster.

On dry prairies in the Minnesota, Sioux, and James valleys; common.

Aster ptarmicoides, (Nees.) T. \& G. Upland White Aster.

In dry rocky or gravelly soils througliout the state.

Aster dumosus, L. Bushy Aster.

In damp, sandy soils in the Sioux valley. 
Aster salicifolius, Lam. Willow Aster.

In low wet ground in the vicinity of streams, through. out the state.

Aster paniculatus, Lam. Panicled Aster.

In low, damp ground from the Missouri valley eastward.

Aster lateriflorus, (L.) Britton. Starved Aster.

Aster diffussis, Ait.

On shady banks in the Sioux valley.

Aster multiflorus, Ait. Dense-flowered Aster.

In dry soils, especially that have been broken, from the Missouri valley eastward.

Aster incanopilosus, (Lindl.) Slieldon. White Prairie Aster.

Aster commutatus, A. Gray.

On dry prairies throughout the state.

Aster Sibiricus, L. Siberian Aster.

Near Custer in the Black Hills.

Aster falcatus, Lindl.

Reported for the Black Hills in Gray's list, Newton and Jenney's report in the Geological survey of the Black Hills in I88o.

Iacharanthera sessiliflora, (Nutt.) Greene. Viscid Aster.

On the dry plains from the Missouri valley westward.

Evigeron asper, Nutt. Rough Erigeron.

Erigeron glabellus, Nutt.

In dry soils in the Black Hills.

Erigeron subtrinervis, Rydberg. Three-nerved Fleabane.

On shaded hillsides in the Black Hills.

Erigeron pumilus, Nutt. Low Erigeron.

On the dry plains from the Missouri valley westward. 
Erigeron canus, Gray. Hoary Erigeron.

In dry soils in the Black Hills and the adjacent plains.

Erigeron compositus, Pursh. Dwarf Fleabane.

On exposed soils in the Black Hills.

Erigeron Hagellaris, Gray. Running Fleabane.

In rich soils in the Black Hills.

Erigeron salsuginous, Gray.

In dry soils in the foothills of the Black Hills and the adjacent plains.

Evigeron pulchellus, Michx. Robin's Plantain.

Erigeron bellidifolius, Muhl.

On banks of streams in the Minnesota and Sioux valleys.

Erigeron Philadelphicus, L. Skevish.

In low ground in the Minnesota, Sioux, and James valleys and in the Black Hills.

Erigeron anmuus, (L.) Pers. Sweet Scabious.

On low prairies in the Minnesota and Sioux valleys.

Erigeron ramosus, (Walt.) B. S. P. Daisy Fleabane.

Erigeron strigosus, Muhl.

In low ground and on banks throughout the state.

Erigeron ramosus Beyrichii, (F. \& M.) Smith \& Pound.

In the Black Hills.

Erigeron armerifolius, Turcz. Mountain Fleabane.

In wet meadows in the Black Hills.

Leptilon Camadense, (L.) Britton. Horseweed.

Erigeron Canadensis, I.

Throughout the state; common in the eastern part of the state; rare from the Missouri valley westwart.

Leptilon divaricatum, (Michx.) Raf. Purple Horseweed.

Erigeron divaricatus, Michx.

In sandy soils in the Missouri valley in Walworth county, rare. 
Doellingeria nmbellata, (Mill.) Nees. Flat-topped White Aster.

Aster umbellatus, Mill.

In swampy places in shaded ravines in the Minnesota valley.

Filago prolifera, (Nutt.) Britton. Filago.

Evax prolifera, Nutt.

On dry hills near Hot Springs in the Black Hills.

Antennaria dioica, (L.) Gaertn. Mountain Everlasting.

In the borders of open woods in the Black Hills.

Antennaria neodioica, Greene. Smaller Cats-foot.

In shady places in the Black Hills. Two of Dr. Rydberg's specimens; 795 collected near Hermosa, 793 near Hot Springs are also referred to this species. They differ from the type in having the leaves tomentose above.

Antennaria campestris, Rydberg. Prairie Cats-foot.

On prairies throughout the state; this is the common species which has been regarded as a form of $A$. plantaginifolia which has not yet been collected in the state. It is likely that it occurs in the open woods in the Minnesota and Sioux valleys.

Antennaria Aprica, Greene.

In the Bad Lands.

Antennaria parvifolia, Nutt.

Along Spring Lake in Brown county.

Anaphalis margaritacea, (L.) B. \& $\mathrm{H}$. Antennaria margaritacea, Hook.

In dry soils in the Black Hills.

Silphium perfoliatum, L. Cup Plant.

In moist thickets in the Minnesota and Sioux valleys.

Silphium laciniatum, L. Compass Plant.

In the southern part of the Sioux, James and Missouri valleys. Sioux Falls, Yaukton, Charles Mix counties. 
Heliopsis scatra, Damai. Kongh (1) Eve.

Common in thickets aud open wooks irom the Missourt viley eastwat. Oxustona! westward along the White and Rad sivers

Rudbeckia hirta, L. Biack-eyed S:sis.

Oz praries in the Minneson and Sionx valleys and in the Black Hills.

Rudbechia laciniata, I. Green-heates Conezower.

In tulcken in the Minuesota, Sioux, and southern Misonuri valleys as far woth as Charles Mix county.

hatibida pimutit. Veat) Barnhart. Gray-headed ConeEomer.

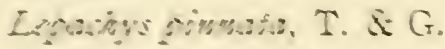

Co low grairies in the Sioux viliey.

hatibida columnaris. Sims.) D. Don. Prarie Conedower.

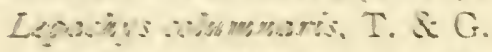

On prairies from the Missonri valley eastward and in tee Biack Hills.

Bramutria pallida. (Nats. Briton. Pale Purple ConeEomer.

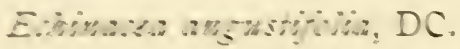

Common on praties irom the Missour ralley enst. ward and in the Black Hills.

Helianthus anmus, I. Comwon Suztower.

Common throughost the state.

Helianthus petiolaris, Nutt. Prairie Sutjomer.

On dry praires inroughout the state: sare from the James ralley eastwart.

Helianthus s'aberriums, Ell. Siẗ Surtorer.

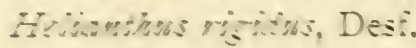

A burcuat on dx praines throughout the state.

Helianthus Maximiliaui, Schnd. Maximitian's Suztiomer.

On rather low pratries throughont the state. 
Helianthus grosse-serratus, Martens. Saw-toothed Sunflower.

In low ground in the Minnesota and Sioux valleys; common.

Helianthus tuberosus, L. Jerusalem Artichoke.

In moist soils in the vicinity of streams, from the Missouri valley eastward.

Helianthus tuberosus subcanescens, Gray.

In the Sioux valley; rare.

Helianthella quinquenervis, (Hook.) Gray. Five-nerved False Sunflower.

On dry knolls in the Black Hills.

Balsamorhiza sagittata, (Pursh.) Nutt. Balsamroot.

In the Black Hills.

Coreopsis tinctoria, Nutt. Garden Tickseed.

In moist soils from the Missouri valley eastward.

Cereopsis palmata, Nutt. Stiff Tickseed.

In the Sioux valley near Sioux Falls; rare.

Bidens laevis, (L.) B. S. P. Smooth Burr Marigold.

In wet meadows in the Black Hills.

Bidens cernua, L. Nodding Burr Marigold.

In wet soils from the Missouri valley eastward.

Biclens connata, Muhl. Purple-stemmed Beggartick.

In swamps in the Sioux valley.

Biclens froudosa, L. Sticktight.

In moist soils from the Missouri valley eastward.

Hymenopappus tenuifolius, Pursh. Woolly Hymenopappus.

On dry plains from the Missouri valley mestward.

Hymenopappus filifolius, Hook. Tufted Hymenopappus.

On dry prairies from the Missouri valley westward.

Bahia oppositifolia, Nutt. Bahia.

On dry plains from the Missouri valley westward. 
Picraclenia acaulis, (Nutt.) Britton. Stemless Picradenia. Actinella acaulis, Nutt.

In dry, gravelly or sandy soils in the Black Hills, and on the hills and buttes from the Missouri valley westward.

Helenium autumnale, L. Sneezewort.

In low, wet places in the Minnesota, Sioux and James valleys.

Gaillarlia aristata, Pursh. Great Flowered Gaillardia.

On dry gravelly banks and knolls in the Minnesota valley and the Black Hills.

Dysodia papposa, (Vent.) A. S. Hitchcock. Fetid Marigold.

Dysodia chrysanthemoides, Lag.

In low places along streams from the James valley westward. In many places in the Missouri valley it has become a bad weed.

Achillea Millefolium, L. Yarrow.

In fields and waste places in the Minnesota and Sioux valleys, and in the Black Hills.

Anthemis Cotula, L. Mayweed.

In waste places from the Missouri valley eastward and in the Black Hills.

Chrysanthemum Leucanthemum, L. White Daisy. Sparingly introduced in the Sioux valley.

Tanacetum vulgare, L. Tansy.

Escaped from gardens in the Sioux and James valleys, rare.

Artemisia Canadensis, Michx. Canada Wormwood.

On sandy hillsides in the Black Hills.

Artemisia caudata, Michx. Wild Wormwood.

In sandy soils throughout the state.

Artenisia dracunculoides, Pursh. Common Wormwood.

In thickets and on prairies throughout the state. 
Artemisia tilifolia, Torr. Silvery Wormwood.

In the Bad Lands conntry just east of the Black Hills.

Artemisia frigirl, Willd. Wormwood Sage.

In loose gravelly soils throughout the state.

Irtemisia biemnis, Wild. Biennial Wormwood.

Introduced from the Missouri valley eastward. A bad weed, native of the Northwest 'Territory.

Artemisia serrata, Nutt. Saw-leaved Mugwort.

In thickets and on low ground, not common.

Artemisia longifolia, Nutt. Long-leaved Mugwort.

On the dry plains from the Missouri valley westward, occasional in the James valley.

MrLemisia gmaphalolles, Nutt. Prairie Mugwort.

Abundant on prairies throughout the state.

Artemisia cana, Pursh. Hoary Sagebrusl.

On the dry plains from the Missouri valley westward.

Petasites sagittata, (Pursh.) Gray. Sweet Coltsfoot.

In the Black Hills near Rochford.

Aruicat cordifolius, Hook. Heart-leaved Arnica.

On shady hillsides in the Black Hills.

Arnica alpina, (L.) Olin. Arctic Arnica. Mountain Tobacco.

In canons and on shady banks in the Black Hills.

Scnecio integerrinus, Nutt. Entire-leaved Croundsel.

Occasional in the Minnesota and Sioux valleys and in the Black Hills.

Senecio lugens, Richards. Black Tipped Groundsel.

On prairies in the Sioux and James valleys and in the Black Hills.

Senecio canus, Hook. Silvery Groundsel.

In dry soils in the Black Hills, a common and variable species. 
Senceio Plattensis, Nutt. Prairie Ragwort.

In dry ground in the Black Hills.

Senecio Balsanitar, Muhl. Balsam Groundsel.

Senecio aureus Balsamite, T. \& G.

On prairies from the Missouri valley eastward and in the Black Hills; connmon.

Senecio anreus, L. Golden Ragwort.

In low, wet ground in the Minnesota and Sioux valleys.

Senceio Douglasii, DC. Douglas' Ragwort.

In dry soils in the plains region, along the Clieyenne river.

Senecio palustris, (L.) Hook. Marsh Ragwort.

In swamps in the Minnesota and Sioux valleys.

Senecio vulgaris, L. Common Groundsel.

Occurs in cultivated and waste ground in the Minnesota and Sioux valleys.

Senecio er(nophilus, Richards. Mountain Ragwort.

On dry soils in the Black Hills.

Senecio rapifolius, Nutt.

In shady places in the Black Hills.

Senceio discoilleus, (Hook.) Britton. Northern Squaw Weed.

In moist ground in the Missouri valley, Charles Mix county. The specimens are typical, except that the achenes are sharply four-sided and hairy on the angles.

Arctiun minus, Schk. Common Burdock.

Sparingly naturalized in shady waste places in the southern part of the Sioux valley and in the Minnesota valley.

Carduns altissimus, L. Roadside Thistle.

Cnicus altissimus, Willd.

In fields, woods and waste places in the Minnesota and Sioux valleys. 
Carduus discolor, (Muhl.) Nutt. Field Thistle.

Cnicus discolor, Mulıl.

On prairies in the Minnesota and Sioux valleys.

Carduns Virginianus, L. Virginian Thistle.

Cnicus Virginianus, Pursh.

In woods and thickets in the Minnesota and Sioux valleys.

Cardums undulatus, Nutt. Wavy-leaved Thistle.

Cnicus undulatus, Gray.

On plains and prairies throughout the state.

Carduus ochrocentrus, (Gray.) Green. Yellow-spined Thistle.

Cnicus ochrocentrus, Gray.

In dry soils in the Black Hills.

Carduus Plattensis, Rydberg. Prairie Thistle.

In sandy soils in the southwestern part of the state.

Carduns Drummondi, (Gray).

Cnicus Drummondi, Gray.

In damp meadows in the Black Hills.

Cardums Carnovirens, Rydberg.

Collected near Sylvan lake in the Black Hills, by Mr. L. W. Carter. Specimens sent Dr. Rydberg were identified as this species.

Caroluus arvensis, (L.) Robs. Canada Thistle.

Cnicus arvensis, Hoff.

Sparingly naturalized in the Sioux valley.

Centaurea Cyanus, L. Blue Bottle. Corn Flower.

Roadsides near Hot Springs in the Black Hills. 



\section{INDEX.}

\begin{tabular}{|c|c|}
\hline PARE & PAGiE \\
\hline Abronia .............. I4 I & American Brooklime....... 193 \\
\hline Abutilon ............ I 7 I & American Mint........... I90 \\
\hline ACERACE, ${ }_{1} \ldots \ldots \ldots \ldots$ I69 & American Spikenard....... 176 \\
\hline Acer $\ldots \ldots \ldots \ldots \ldots \ldots \ldots \ldots$ & Ammannia ............ 174 \\
\hline Acerates $\ldots \ldots \ldots \ldots \ldots \ldots$ I $8_{3}$ & Amorpha............. I6o \\
\hline Achillea............... 2 Io & Ampelopsis............. 171 \\
\hline Acnida................ I40 & Amphicarpa............ 165 \\
\hline Aconitunı $\ldots \ldots \ldots \ldots \ldots$ I 44 & ANACARDIACE $A \ldots \ldots \ldots$ I 69 \\
\hline Acorus ............... I 25 & Anaphalis ............. 207 \\
\hline Actinella............... 2 Iо & Andropogon $\ldots \ldots \ldots \ldots \ldots$ rog \\
\hline $\operatorname{Actæa} \ldots \ldots \ldots \ldots \ldots \ldots \ldots$ I 44 & Androsace $\ldots \ldots \ldots \ldots \ldots$ I I I \\
\hline Acuan $\ldots \ldots \ldots \ldots \ldots \ldots \ldots \ldots \ldots$ & Anemone.............. 144 \\
\hline Adder-Tongues $\ldots \ldots \ldots \ldots \ldots$ ro3 & ANGIUSPERMS ......... 106 \\
\hline Adiantum .............. I04 & Anogra............... I75 \\
\hline Adicea ................ I 35 & Antennaria ........... 207 \\
\hline A DOXACE $\ldots \ldots \ldots \ldots \ldots \ldots$ & Anthemis $\ldots \ldots \ldots \ldots \ldots \ldots .210$ \\
\hline Adoxa ................ 196 & Aphyllon................ I94 \\
\hline Agastache $\ldots \ldots \ldots \ldots \ldots$. 188 & Apios $\ldots \ldots \ldots \ldots \ldots \ldots \ldots \ldots$ \\
\hline Agoseris $\ldots \ldots \ldots \ldots \ldots \ldots \ldots$ 198 & Aplopappus ............. 202 \\
\hline Agrimonia............. 156 & APOCYNACEA $\ldots \ldots \ldots \ldots \ldots$ I $8_{3}$ \\
\hline Agropyron ............. II & A pocynum............ I $8_{3}$ \\
\hline Agrostemma............ I42 & e Family............ r 56 \\
\hline Agrostis ................ I I 3 & Aquilegia ............. 144 \\
\hline Alexander.............. 178 & Arabis $\ldots \ldots \ldots \ldots \ldots \ldots \ldots \ldots \ldots \ldots \ldots$ \\
\hline Alisma ............... Io & ARACE $A \ldots \ldots \ldots \ldots \ldots \ldots \ldots$ \\
\hline ALISMACE正 . . . . . . . . & ARALIACE $\Phi, \ldots \ldots \ldots \ldots \ldots$ I 76 \\
\hline Allium .............. I 27 & Aralia............. I 76 \\
\hline Allionia............... I 40 & Arctium ............... 212 \\
\hline Allocarya ............. I86 & Arctostapylos........... I80 \\
\hline Alopecurus ........... I 2 & Arenaria $\ldots \ldots \ldots \ldots \ldots \ldots$ I 43 \\
\hline Alsine............... I4I & Argemone ............. 147 \\
\hline Alum-root............. I52 & Arisæma $\ldots \ldots \ldots \ldots \ldots \ldots \ldots \ldots \ldots$ \\
\hline AMARANTHACE $\mp \ldots \ldots \ldots \ldots$ I 40 & Aristida $\ldots \ldots \ldots \ldots \ldots \ldots$ I I I \\
\hline Amaranths ............. I 40 & Arnica $\ldots \ldots \ldots \ldots \ldots \ldots$ \\
\hline Amaranthus $\ldots \ldots \ldots \ldots \ldots$ I 40 & Arrhenatherum ........... II 4 \\
\hline AMARYLIIDACE E $\ldots \ldots \ldots \ldots$ I 30 & Arrow-grass ............. I08 \\
\hline Amaryllis............... I 30 & Arrowhead .............. Ios \\
\hline AMBROSIACEA $\ldots \ldots \ldots \ldots .200$ & Artemisia $\ldots \ldots \ldots \ldots \ldots \ldots \ldots \ldots$ I \\
\hline Ambrosia .............. 200 & Artichoke .............. 209 \\
\hline Amelanchier $\ldots \ldots \ldots \ldots \ldots$ I 57 & Arums $\ldots \ldots \ldots \ldots \ldots \ldots \ldots \ldots \ldots$ \\
\hline
\end{tabular}




\begin{tabular}{|c|c|}
\hline PAGE & \\
\hline SCLEPIADACE $\mathbb{A} \ldots \ldots \ldots \ldots$ I $8_{3}$ & Black-eyed Susan.......... \\
\hline sclepias $\ldots \ldots \ldots \ldots \ldots \ldots \ldots$ & Black Mustard............ \\
\hline $\operatorname{sh} \ldots \ldots \ldots \ldots \ldots \ldots \ldots$ isi & Black Raspberry......... \\
\hline sparagus ............ I 28 & Black Snakeroot........... \\
\hline $\operatorname{spen} \ldots \ldots \ldots \ldots \ldots \ldots \mathrm{I}_{32}$ & Black Walnut ............ \\
\hline splenium ........... IO4 & Bladder Campion.......... \\
\hline ster .............. 204 & Bladder-pod .............. \\
\hline stragalus $\ldots \ldots \ldots \ldots \ldots \ldots$ i6 & Bladderwort ............ \\
\hline triplex ................ 139 & 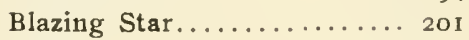 \\
\hline vena............. I 4 & 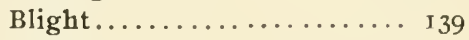 \\
\hline vens $\ldots \ldots \ldots \ldots \ldots \ldots \ldots \ldots \ldots$ & 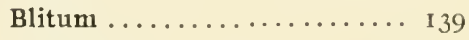 \\
\hline Bahia ............... 2c9 & 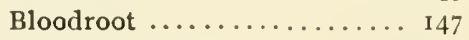 \\
\hline ALSAMINACE & Blue Cohosh............ \\
\hline Balsamorrhiza ........... 209 & eyed Grass ........... \\
\hline alsam Poplar.......... I32 & oint $\ldots \ldots \ldots \ldots \ldots \ldots$ \\
\hline Balsamroot ............ 209 & ia................ \\
\hline Baneberry ............. I 44 & et $\ldots \ldots \ldots \ldots \ldots \ldots 20$ \\
\hline arberry $\ldots \ldots \ldots \ldots \ldots \ldots 147$ & BORAGINAGEA $\ldots \ldots \ldots$ I \\
\hline Barny ard-grass .......... I09 & Borage Family .......... \\
\hline Basswood.............. I I I & Botrychium ... $\ldots \ldots \ldots$ Is \\
\hline Bastard Toad-flax......... I35 & Bottle Brush........... I \\
\hline Batrachium............ I46 & Bouncing Bet.......... I4 \\
\hline erry $\ldots \ldots \ldots \ldots \ldots$ r8o & loua $\ldots \ldots \ldots \ldots \ldots$ II \\
\hline Beard-grass............ I 09 & Box Elder ............ I 7 \\
\hline d-tongues .......... I92 & Brachyelytrum .......... \\
\hline 's-grass $\ldots \ldots \ldots \ldots \ldots$ 12S & Brake ............... Io \\
\hline Beckmannia ........... I I 5 & Brassica .............. \\
\hline Beckwith's Clover ......... I59 & eria $\ldots \ldots \ldots \ldots \ldots \ldots$ \\
\hline Bedstraws ............. I95 & Brewer's Cliff-brake......... \\
\hline Bellwort Family .......... I97 & e-fern...$\ldots \ldots \ldots \ldots$ \\
\hline Bellwort.............. 1 27 & Brome ................. \\
\hline Bent-grass ............ I 3 & 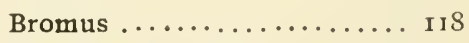 \\
\hline BERBERIDACE王 . . . . . I 47 & Broomrape Family......... \\
\hline beris ............ I47 & Buckbean Family........... \\
\hline Berula ................ 179 & Buckthorn Family.......... \\
\hline BETULACE $A \ldots \ldots \ldots \ldots \ldots$ I 33 & Buck wheats. . . . . . . . . . \\
\hline Betula................ I 33 & Buffalo Berry ............. \\
\hline Bicuculla ............. 147 & Buffalo Burr............. \\
\hline Bidens ............... 209 & Clover .............. \\
\hline Bigelovia ............. 202 & Buffalo Currant ............ \\
\hline Bilberry ............. & lo Grass .............. \\
\hline Bindweed ............ I 84 & Buffalo Pea............. \\
\hline Birch ............... 133 & Bug-seed .............. \\
\hline Bird's-foot Trefoil......... I6o & Bulbilis $\ldots \ldots \ldots \ldots \ldots \ldots$ I \\
\hline Bittersweet ............ I69 & Bulrush ............ 12 \\
\hline Bitterweed ............ 200 & Bunch-flowers .......... I 2 \\
\hline Black Cherry ............ ${ } 58$ & Bupleurum ........... 7 \\
\hline
\end{tabular}


Burdock ........... 2 I 2

Bur-head ................ Ios

Burning Bush... . . . . . . . . . I69

Burr Cucumber ..... ........ 197

Bur-reed ................. I06

Burr Marigold ....... ..... 209

Burr Oak................ I 34

Bursa ................. I 50

Bush Clover ............... I 64

Bushy Blue-stem.......... I I09

Buttercups .............. I44

Butterfly Weed............. I $\mathrm{S}_{3}$

Button Snakeroot .......... 201

CASALPINACEA .......... I 58

CACTACE.F. . . . . . . . . . . 173

Cactus Family............ 173

Cactus................... 173

Calamagrostis ............ I I 4

Calamovilfa ............... I I 4

CaltitrichaCE $A$. . . . . . . . I 68

Callitriche............... I 68

Calochortus .............. I 28

Caltha .................. I44

Camelina................ I 50

Campanulace $\mathrm{A} ; \ldots \ldots . . . . .197$

Campanula ............... I97

Canary Grass .............. I Io

Cancer Root................. I94

Canoe Birch .............. I33

Cannabis ................ I 34

Caper Family............. I52

Capnoides.............. I 48

CapParidaCE $\ldots \ldots \ldots \ldots \ldots 152$

CaPRIFOLIACE 1 .......... 195

Capsella................ 150

Caraway ................ 179

Cardamine.............. 149

Carduus............... 212

Carex ................. 122

Carrion Flower ............ I 29

Carrot Family ............ I 77

Carum.................. I 79

Caryophylatace

Cassia.................. I 58

Castilleja................. I93

Catabrosa ................ II6

Catchfly............... I 4 I
Catnip ................ 188

Cat's-foot............... 207

Cat-tails ................. I06

Caulophyllum ........... I 47

Ceanothus .............. I70

Cemastrace.t: .......... I6g

Celastrus............... I69

Celtis ................. I 34

Centaurea ............... 2 I 3

Centunculus ............. I8 I

Cerastium ................ 142

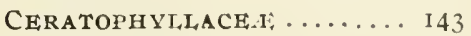

Ceratophyllum ............ I43

Cercis .................. I $5^{8}$

Cercocarpus .............. I56

Chaffweed ............... I 8 I

Chamanerion ............. I74

Cheeses ................ I7 I

Cheilanthes ................ I04

Cenchrus................ I Io

Chenopodiace. ......... I $3 S$

Chenopodium ............ I 38

Cherries ................ I57

Chickweed ............. . I4 I

Chicory Family............. I9s

Choke Cherry ........... I 58

Chrysanthemum ......... 210

Chrysopogon ............. I09

Chrysothamnus.......... 202

Cichoriace.

Cicuta................. I I79

Cinna ................. I I 3

Cinquefoils ............... 154

Circra ................. I 76

Cistace $\ldots \ldots \ldots \ldots \ldots \ldots . \ldots . \ldots 72$

Clammy-weed ............ I 52

Claytonia ............. I4 I

Clearweed ............... I 35

Cleavers................ I95

Clematis................. I45

Cleoma................. 152

Cliff-brake............... IO 4

Clovers ................... I59

Club Mosses............... 105

Club Rushes.............. I2 I

Cnicus ...............2 $2 \mathrm{I}_{3}$

Cocklebur ............... 200 
Colicroot $\ldots \ldots$ PAF

Collinsia ................ I92

Collomia ............... $18_{5}$

Columbine ............... I44

Comandra ............... I 35

Comaremina CEA:.......... 126

Compass Plant........... 207

Compostrat ............. 200

CONVALLARIACEA: . . . . . . I $2 S$

Convolvur,ACE, $\mathrm{x}$. . . . . . . I $\mathrm{S}_{4}$

Convolvulous ............. I $S_{4}$

Corallorhiza ............. I3I

Coral-root ............... I3I

Cord-grass ............... I I5

Coreopsis................. 209

Coringia................ 152

Corispernum . . . . . . . . . . . . . . 139

Cornace. ............... 179

Corn Cockle .............. I 42

Cornel .................. I 79

Cornflower ............. 213

Cornus .................. I79

Corydalis................ I 48

Corylus ................ 133

Cottonwood .............. 132

Cotton-grass ............ 121

Couch-grass ............. I 18

Cow-herd ................ I4I

Cow-parsnip ............. 177

Cowslip ................ ISI

Crab-grass ................. 109

Cranberry Tree ............ I95

Crane's Bills.............. I66

Crassurace.

Cratregus................ 157

Creeping Red Cedar......... 106

Crepis................. . 199

Cress.................... 149

Crotalaria ............... 159

Croton ................ 167

Crowfoots .............. 144

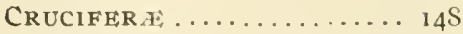

Cryptotcenia.............. 179

Cryptanthe ............... I $\$ 6$

Cuckoo-flower............. 150

CucurbitackA: . . . . . . . . . 197

Culver's Root............. 193
PAGE

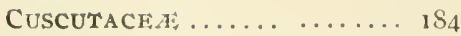

Cuscuta ................ ${ }_{1 S_{4}}$

Cup Plant ............. 207

Currant ................ I 53

Cycloloma ................ I 39

Cymopterus ............. 177

CyPerace $1 . \ldots \ldots \ldots \ldots . . . .120$

Cyperus ................ 120

Cypripedium ........... 130

Cystopteris . ............. $10_{3}$

Dactylis ................ I 16

Dakota Vetch.............. I60

Dalea.................. 161

Dandelion ............... Igs

Danthonia................ I 15

Daucus................. 177

Delphinium .............. . I 44

Deringis ................ 179

Desmanthus............. I5s

Desmodium ............... 164

Dicentra................. 147

DICOTYLEDONE - ....... 13 I

Diplachne ............. 115

Diosporum ................ 129

Distchlis .............. 116

Docks.................. 136

Dodder Family ............ . IS4

Dodecatheon ............. ${ }_{1} S_{I}$

Doellingeria............. 207

Dogbane Family............ ${ }_{1} S_{3}$

Dogwood Family .......... I 79

Dogwoods................ 179

Dondia.................. I39

Draba ................. 150

Dracocephalum ........... 189

Dragonbead ............... I 89

DRUPACE.F. . . . . . . . . . . 157

Dryopteris............... 104

Duckweeds .............. 126

Dutchman's Breeches ....... 147

Dwarf Cornel............. 179

Dysodia ............... 210

Eatonia ................ I 16

Echinacea............. $20 S$

Echinocystis ............ 197

Echinodorus............. IOS

Echinospermum .......... 186 


\begin{tabular}{|c|c|}
\hline PAGE & \\
\hline Echium ............. 187 & Flag $\ldots \ldots \ldots \ldots \ldots \ldots \ldots \ldots \ldots \ldots$ \\
\hline EIATINACE $A \ldots \ldots \ldots \ldots$ I 72 & Flax Family,.......... 166 \\
\hline Elatine............ I72 & Fleabanes ............. 205 \\
\hline Elder ............... r95 & Flowering Plants.......... I06 \\
\hline ELAEAGNaCE $E_{1} \ldots \ldots \ldots \ldots$ I 74 & Fogfruit $\ldots \ldots \ldots \ldots \ldots \ldots$ I $S_{7}$ \\
\hline Elaeagnus ............ 174 & Forget-me-not $\ldots \ldots \ldots \ldots \ldots$ I 87 \\
\hline Eleocharia ............ I 20 & Four-o'clocks........... 140 \\
\hline Eel-grass ............. 108 & Foxtail............. 110 \\
\hline Ellisia ............... I $\mathrm{S}_{5}$ & Fragaria $\ldots \ldots \ldots \ldots \ldots \ldots$ \\
\hline Elm $\ldots \ldots \ldots \ldots \ldots \ldots \ldots \ldots$ & Franseria............. 200 \\
\hline Elymus .............. I19 & Frasera $\ldots \ldots \ldots \ldots \ldots \ldots \ldots \ldots$ \\
\hline Enchanter's Nightshade..... I 76 & Fraxinus $\ldots \ldots \ldots \ldots \ldots \ldots$ 18r \\
\hline Epilobium............ I 74 & ged Orchis ........... 131 \\
\hline Equisetum ............ Iu5 & Fritillaria $\ldots \ldots \ldots \ldots \ldots$ I 28 \\
\hline EQUISETACE E $_{\text {. . . . . . . } 105}$ & ed $\ldots \ldots \ldots \ldots \ldots 1_{72}$ \\
\hline Eragrostis ............ 116 & ia ............ 200 \\
\hline ERICACEA $\ldots \ldots \ldots \ldots \ldots$ ISO & dia ..............210 \\
\hline Erigeron .............. 205 & $m \ldots \ldots \ldots \ldots \ldots \ldots \ldots$ \\
\hline Eriocarpum ........... 202 & Garlics .............. 128 \\
\hline Eriogonum ........... 135 & vaura $\ldots \ldots \ldots \ldots \ldots \ldots \ldots \ldots \ldots \ldots$ \\
\hline Eriophorum ........... 12I & yton $\ldots \ldots \ldots \ldots \ldots 176$ \\
\hline Eryngium ............ I77 & $\operatorname{ACE} A \ldots \ldots \ldots \ldots, 8_{2}$ \\
\hline${ }_{11 u m} \ldots \ldots \ldots \ldots \ldots \ldots$ 15 $^{\mathrm{I}}$ & $\ldots \ldots \ldots \ldots \ldots{ }_{1} 8_{2}$ \\
\hline Euonymus ............ 169 & Gentian Family......... I 82 \\
\hline Eupatorium ........... 200 & ans $\ldots \ldots \ldots \ldots \ldots \ldots \ldots \ldots \ldots$ \\
\hline EUPHORBIACEA $\ldots \ldots \ldots \ldots .167$ & CEA $\ldots \ldots \ldots \ldots 166$ \\
\hline horbia............ 167 & am Family......... I66 \\
\hline Eurotia ............. 139 & $\operatorname{um} \ldots \ldots \ldots \ldots \ldots \ldots$ \\
\hline Euthamia ............ 203 & Gerardia $\ldots \ldots \ldots \ldots \quad \ldots \ldots 193$ \\
\hline Evax .............. 207 & nander.............. 188 \\
\hline ng Primrose Family.... 174 & Geum ................. \\
\hline ng Primrose......... 174 & Giant Hyssop........... I 88 \\
\hline Evolvulus ............. I 84 & Gilia............... I 85 \\
\hline FAGACE, E $\ldots \ldots \ldots \ldots \ldots \ldots$ I 34 & Ginseng Family......... 176 \\
\hline Falcata.............. $16_{5}$ & wort $\ldots \ldots \ldots \ldots \ldots \ldots$ \\
\hline False Indigo............. I60 & Gleditsia $\ldots \ldots \ldots \ldots \ldots \ldots{ }_{1} 5^{8}$ \\
\hline False Pimpernel ......... 192 & Glyceria.............. I17 \\
\hline e Red-top . . . . . . . . I 7 & Glycyrrhiza $\ldots \ldots \ldots \ldots \ldots$ I64 \\
\hline Fame-flower........... r 4 r & Golden Aster ............ 202 \\
\hline Ferns................ ${ }_{10} 3$ & Goldenrods............. 203 \\
\hline Fescue $\ldots \ldots \ldots \ldots \ldots \ldots$ II & Goodyera $\ldots \ldots \ldots \ldots \ldots$ I3 \\
\hline Festuca $\ldots \ldots \ldots \ldots \ldots \ldots$ II & Gooseberry ............. I 53 \\
\hline Fetid Marigold ........... 2 ro & Goosefoots ............ I3S \\
\hline Figwort Fanily.......... 191 & Goosegrass ............. 194 \\
\hline Filago............... 207 & Gourd Family ........... 197 \\
\hline Finger Grass ........... 109 & GRAMINEA $\ldots \ldots \ldots \ldots$ IOG \\
\hline Fireweed ............. 174 & Grape Family........... 170 \\
\hline
\end{tabular}


PAGE

Grape-fern............... $\mathrm{IO}_{3}$

Grapes ................. I70

Grasses................. IO

Grass of Parnassus ......... I 52

Greeil Ash.............. I 8 I

Greenbrier.............. I 30

Grindelia.............. 202

Gromivell ............... I $S_{7}$

GROSSULARIACEA . . . . . . . . I I53

Ground Cherry ............ I99

Groundnut ............. I65

Ground Pine ............ 105

Ground Plum............ I6

Groundsel .............2 2 II

Gum Plant ............ 202

Gutierrezia............. 202

Gymnocladus ............ I 5 Xे

GyMnosprerm F.......... Jo5

Gymnosperms ............ I05

Gyrostachys ............. I 3 I

Habenaria............... I 30

Hackberry.................. I 34

HAL,ORAGIDACE $\mathrm{A}$. . . . . . . . I 76

Harebell ................. 197

Hare's-ear Mustard . . . . . . . I I52

Hazelnut .............. I33

Hawkweed ........... . . . . . I99

Heath Family ............ I 80

Hedeoma ............... I 89

Hedge Bindweed........... 184

Hedge Hyssop. . . . . . . . . . . I92

Hedge Mustard ........... I 48

Hedge Nettle........... . . 189

Hedysarum.............. 164

Helenium ............. 2 Io

Helianthella ............. 209

Helianthemum .......... 172

Helianthus .............. 208

Heliopsis .............. 208

Heliotropium ........... 185

Hemp ................ I34

Heracleum ........... . I 77

Herpestis............. . . 192

Heteranthera........... I 26

Heuchera............... I52

Hibiscus .............. I7

Hieracium................ I99
Hierochloe .............. III

Hippuris ............. I76

Hoarhound ............. I90

Hog Peanut ............. I 65

Homalobus .............. I 6.3

Homalocenchrus........... I Jo

Honewort .............. I79

Honeysuckle Family........ I95

Hop Clover............... I59

Hops................... I 34

Hordeum................ I I9

Hornwort . . . . . . . . . . . I 43

Hosackia .............. I60

Horseradish .............. I 49

Horse-tails ... ........... 105

Horseweed ............. 206

Huckleberry Family ........ I so

Humulus ... . . . . . . . . . 134

Hungarian Grass........... I IO

HYDROPHYLLACE, . . . . . . I $\mathrm{S}_{5}$

Hydrophyllum........... I $8_{5}$

Hymenopappus ........... 209

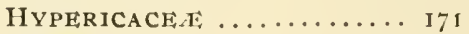

Hypericum ............. I7 I

H ypoxis................. I 30

Hyssop ................. I $S 9$

Hyssopus................ 190

Hysanthes .............. 192

Impatiens ............... I70

Indian Hemp............. $1 S_{3}$

Indian Mallow............ I I I

Indian Pipe Family......... ISo

Indian Pipe.............. I so

Indian Rice............... I 10

Indian Soapweed........... I $2 S$

Indian Turnip ............ I 25

I pomcea ................. $18_{4}$

IRIDACE $A: \ldots \ldots \ldots \ldots$ I 30

Iris ................. I 30

Ironweed ............ 200

Iroulwood ............. I33

Iva ................. 200

Ixophorus ............... 110

Jewel-weed Family.......... I70

JUNCACE $A$............... 126

Juncus ................. I 26

Juncoides............... I 27 
PAGE

JUGDLANDACEA $\ldots \ldots \ldots \ldots$ I 3 I

Juglans.............. I3 I

June Berry ............ I57

Juniper.............. 106

Juniperus............... I06

Kentucky Blue-grass........ I 6

Kentucky Coffee-tree ....... I58

Knot-grass ............. 137

Knot-weed ............. I37

Koeleria.............. I 6

Krynitzkia ........... I 86

Kuhnia ............. 201

Kunistera ............ I6I

LABIATA:............ I 88

L aciniaria ............. 20 I

Lactuca ............... Ig

Ladies' Slipper ........... I30

Ladies' Tresses ........... I3 I

Jady-fern ............. IO4

Lamb's quarters ........... I3 8

Laportea ............... I 35

I.appula.............. I 86

Larkspur ............ I44

Lathyrus ............. 165

J.ead Plant ............. 160

Leeks................ 1.27

Leersia ................. I Io

Legouzia ............... 197

Lemna .............. 126

LEMNACE.$\ldots \ldots \ldots \ldots \ldots$ I 26

LENTIBULARIACE . . . . . . . I94

* Leonurus .............. 189

Lepachys............... 208

Lepargyræa ............. I74

Lepidium............. . I4 8

Leptandra............... I93

Leptilon.............. 206

Lespedeza .............. 164

Lesquerella............. I50

Lettuce............... I98

Leucocrinum ........... 527

Liatris............... $20 \mathrm{I}$

Lithospermum.......... ${ }^{8} 87$

LILIACE $A \ldots \ldots \ldots \ldots \ldots \ldots, 127$

Lilies............... . 127

Lilium............... I 28

Lily of the Valley....... . I I 28

IIVACE IE . ................. 166

Linaria............... I9I

Linden Family.......... I7 I

Linnaea................ 196

Linum............... I 66

Lip-fern.............. 104

Lippia............... I $S_{7}$

Little Club Mosses......... In

LOASACE $A \ldots \ldots \ldots \ldots \ldots$. 173

Loasa Family ........... I 73

Lobelia................ 197

Loco-weed............. I6 $6_{3}$

Louicera................ I96

Loosestrife Family.......... I 74

Loosestrife............. I74

Lophanthus ............ I 89

Lophotocarpus............ 108

Lopseed................. 194

Lotus ... . ............ 160

Lousewort .............. I93

Luetkea .............. I54

Lungwort ............ I 87

Lupines............... 159

Lupinus............... I59

Lychnis.............. I4 I

LYCOPODIACE

Lycopus............... I90

Lycopodium............. 105

Lygodesmia............. I9s

Lysimachia............ I8 I

LYTHRACE $\mathrm{A}, \ldots \ldots \ldots \ldots \ldots$. . I 74

Lythrum.............. I74

Machæranthera.......... 205

Macrocalyx............ I $\mathrm{I} 5$

Madder Family........... I94

Mahonia.............. I 47

Maiden-hair.............. 104

Majanthemum........... I29

Male-fern.............. 104

Mallow Family.......... I7 I

Malva.............. I I I

MaLVACEA........... I I I

Malvastrum ............ I I I

Mamillaria............ I 73

Manna Grass............ II 7

Maple Family............. 169

Mariposa Lily ........... I2 8 


\begin{tabular}{|c|c|}
\hline PAGE & \\
\hline Marsh Foxtail. ............ II 2 & Moss Champion .... \\
\hline Marsh Marigold.......... I 44 & Moschatel Family....... \\
\hline Marsilea............... IO 4 & Motherwort. .......... \\
\hline MARSILEACE F . . . . . . . IO4 & Mountain Ash............. \\
\hline Matthiola............. I5 & Hountain Rice............ \\
\hline Matricary Grape fern....... 103 & Iouse Tail.............. \\
\hline Mayweed............... 2 Io & Iud Plantain. . . . . . . . . . \\
\hline Meadow Grass........... II & lenbergia............. \\
\hline Meadow Parsnip......... I 7 S & Mulberry.............. \\
\hline Meadow Rue............. I47 & Iullen ................. \\
\hline Meadow-sweet. . . . . . . . . 154 & roa $\ldots \ldots \ldots \ldots \ldots \ldots$ \\
\hline Meibomia.............. I64 & Musineon $\ldots \ldots \ldots \ldots \ldots \ldots$ \\
\hline MELANTHACE $A \ldots \ldots \ldots \ldots \quad 127$ & Iustard Family.......... \\
\hline Melilotus . . . . . . . . . . . 159 & osotis $\ldots \ldots \ldots \ldots \ldots \ldots$ \\
\hline MENISPERMACEA: . . . . . I 47 & arus.............. \\
\hline Menispermum ........... 147 & hyllum ............. \\
\hline Mentha ................ I90 & us $\ldots \ldots \ldots \ldots \ldots \ldots \ldots$ \\
\hline Mentzelia ............ I73 & $A \ldots \ldots \ldots \ldots \ldots \ldots$ \\
\hline MENYAN'THACE $1 . . \ldots \ldots \ldots \mathrm{IS}_{2}$ & NAIADACE $x_{1} \ldots \ldots \ldots \ldots$ \\
\hline Menyanthes ............ $\mathrm{IS}_{2}$ & $\mathrm{~s} \ldots \ldots \ldots \ldots \ldots \ldots$ Is \\
\hline Meriolix............. . 175 & urtium ........... I \\
\hline Mertensia............ $\mathrm{I}_{7}$ & pergia $\ldots \ldots \ldots \ldots \ldots$. \\
\hline Mesquite Grass.......... I 15 & eed $\ldots \ldots \ldots \ldots \ldots \ldots$. \\
\hline Micrampelis . . . . . . . . 197 & $\operatorname{ta} \ldots \ldots \ldots \ldots \ldots \ldots$ I \\
\hline Milk Purslane ........... I67 & $s \ldots \ldots \ldots \ldots \ldots \ldots$ I \\
\hline Milk Vetches............ 162 & Nightshades ............. \\
\hline Milkweed Family.......... I $s_{3}$ & ark................ \\
\hline Milkwort Family......... I67 & Northern spleauwort....... 10 \\
\hline MIMOSACEA $\ldots \ldots \ldots \ldots \ldots$ I5S & Nothocalia .......... \\
\hline Mimosa Family........... ${ }_{15}$ & AGINACE, $\ldots \ldots \ldots \ldots$ I4 \\
\hline Mimulus . . . . . . . . I92 & phiea .............. 14 \\
\hline Mint Family ............ ISS & IPH $\nRightarrow, \mathrm{ACE}, 1: \ldots \ldots \ldots \ldots, \mathrm{I} 4$ \\
\hline Modesty............... 179 & Oak-fern ............... \\
\hline Mœhringia ........... 143 & Oat-grass ............. II \\
\hline Monarda ............. 189 & hera ............ 17 \\
\hline MIONOCOTYLEDONS...... IO6 & CEA $\ldots \ldots \ldots \ldots \ldots$ IS \\
\hline Monkey Flower............ 192 & ter Family.......... I74 \\
\hline Monkshood ............ & Olive Family............ Is \\
\hline onniera............ 192 & Onagra.............. 175 \\
\hline Monolepis ............... I 39 & ONAGRACE.F $\ldots \ldots \ldots \ldots \ldots$ I 7 \\
\hline onotropa............ ISo & Onoclea $\ldots \ldots \ldots \ldots \ldots \ldots$ I0 3 \\
\hline MONOTROPACE. E........ ISO & Onosmodium ........... IS \\
\hline Ioonseed Family.......... 147 & OPHIOGLOSSACEA. . . . . . . IO \\
\hline ORACE王......... I 34 & Opulaster............. I 53 \\
\hline Lorning Glory Family....... I $S_{4}$ & Opuntia .............. I 7 \\
\hline orongia............. 158 & Orchard-grass $\ldots \ldots \ldots \ldots \ldots$ i 16 \\
\hline Iorus................... & ORCHIDACE $A_{1} \ldots \ldots \ldots \ldots \ldots$ I 30 \\
\hline
\end{tabular}


PAGE

Orache .................. I39

Oreocarya.................. I 86

Oregon Woodsia........... Io3

Orchids ............... I 30

OROBANCHACEA . . . . . . . . I 194

Orobanche ............... 194

Orophaca................ I63

Orpine Family............. I 52

Orthocarpus .............. I93

Oryzopsis................ I I I

Osinorrhiza.............. 178

Ostrich-fern............. $10_{3}$

Ostrya.................. I 33

OXALIDACE.I: ............. I66

Oxalis................. I66

Ox Eye................... $20 S$

Oxygraphis.............. I46

Oxytropis ................ I6 3

Pachylophus.............. I75

I'ainted Cıp............... I93

Panicularia .............. 117

Panicum ............... 109

PAPAVERACE.F. . . . . . . . . 147

PAPILLIONACE........... I 5 S

Parietaria ............... I 35

Parnassia............... I52

Paronichia .............. 143

Parosela................. 56 I

Parsley.................. 177

Parsnip............... 17

Parthenocissus........... I70

Pasque Flower............. I 45

Pastinaca.............. I77

Pea Family.............. 558

Pedicularis ................ I93

Pellaea.................. I04

Pellitory ................ I 35

Pennyroyal............... I 89

Penthorum .............. I52

Pentstemon.............. I9 I

Pepper-grass.............. I48

Peramium .............. I3I

Persicaria ............... I36

Petalostemon .............. I6I

Petasites................ 2 II

Peucedanum............. I77

Phaca ................ ${ }_{16} 6_{3}$
PAGE

Phalaris ................. I Io

Phegoptoris ............. $\mathrm{IO}_{3}$

Philotria ............... I08

Phleum ............... I I 2

Phlox................ I $8_{5}$

Phlox Family............ $\mathrm{I}_{5}$

Phragmites ............... I I5

Phryma ................. 194

PHRYMACE 1 . . . . . . . . . . . . 194

Physalis................ 190

Physaria ............... 150

Physostegia .............. Isg

Picea.................. 105

Pickerel-weed ............. J 26

Picradenia............... 210

Pigeon grass. . . . . . . . . . . . I 10

Pigweed.................. 138

Pilea................... I35

PinackA: Pinus.......... 105

Pine Drops............... I 80

Pinks.................. I4 I

Plantaginace $\mathrm{F}$. . . . . . . . . . . 194

Plautago ... . . . . . . . . . . . . 194

Plantain Family ........... I94

Pleurisy Root............. $18_{3}$

Plum Family............. I57

Poa .................... 116

Poison Ivy . . . . . . . . . . . . . . . 169

Poison Oak................ 169

Polanisia ............... 152

POLEMONIACEA . . . . . . . I 85

Polygala ............... 167

POLYGALACEA . . . . . . . . I67

POLYGONACEA ............ I 35

Polygonatum .............. 129

Polygomum .............. 136

POLYPODIACEAE............ 103

Polypodium .............. $\mathrm{IO}_{4}$

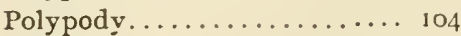

POMACEA ............... 156

Pond Lily . . . . . . . . . . . . . . I43

Pond Weed.............. I06

Poplar. ................ I 32

Poppy Family............ I 47

Populus ................. I32

Porcupine Grass........... III

Portulaca............... I4I 


\begin{tabular}{|c|c|}
\hline PAGE & PAGE \\
\hline PORTULACACE $A: \ldots \quad \ldots \ldots$ I4I & Reed Grass.............. 113 \\
\hline Potamogetoll........... 106 & RHAMNACEA......... I 70 \\
\hline Potato Family........... I90 & Rhus............... I6g \\
\hline PONTEDERIACEA . . . . . I 26 & Ribes .............. I53 \\
\hline Potentilla ............. I 54 & Rice Cut-Grass........... IIo \\
\hline Powder-liorn ............ I42 & Rock-cress ............ I5 I \\
\hline Prairie Clover........... I6I & Rock Maple... .. . ..... I6g \\
\hline Prairie Turnip .......... I60 & Rocky Mountain Woodsia... I03 \\
\hline Prenanthes............. 199 & Rock-rose Family........ I 72 \\
\hline Prickly Ash............ 167 & Roripa............... I 48 \\
\hline Prickly Peir............ I 73 & Rosa................. ${ }_{156}$ \\
\hline Primrose Family.......... I $S_{I}$ & ROSACEA $\ldots \ldots \ldots \ldots \ldots$ I 53 \\
\hline Prosartes.............. I 29 & Rose Family............ I53 \\
\hline 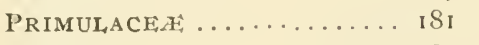 & Roses .............. I56 \\
\hline Prunella ............. I 89 & Rudbeckia .............. 208 \\
\hline Prunus .............. I 57 & RUBIACE $A ;. \quad \ldots \ldots \ldots \ldots \ldots$ I94 \\
\hline Psoralea............... I6o & Rubus.............. I54 \\
\hline PTERIDOPAYTES........ IO 3 & Rue Family............ I67 \\
\hline Pteris....... . . . . . IO 4 & Rumex.............. I36 \\
\hline Pterospora ............ ISo & Ruppia............... Io7 \\
\hline uccoon............... I $8_{7}$ & Rushes ............. I 26 \\
\hline Purple-stemed Cliff-brake.... IO 4 & Rush-grass ............ II 2 \\
\hline lane ............. I 4 I & Russian Thistle.......... I39 \\
\hline ley............ I 4 I & RUTACEA $\ldots \ldots \ldots \ldots$. . . 167 \\
\hline Pulsatilla . . . . . . . . . I 45 & Sage $\ldots \ldots \ldots \ldots \ldots \ldots \ldots$ I $\delta_{9}$ \\
\hline ola................ Iso & Sagebush............. 211 \\
\hline PYRol,ace & Sagittaria.............. 108 \\
\hline Pyrus .............. I57 & SALICACEAE. . . . . . \\
\hline Quack-grass ............. I 8 & Salicornia ............. I 39 \\
\hline amoclit $\ldots \ldots \ldots \ldots \ldots \ldots$ I $\mathrm{S}_{4}$ & balix... . . . . . . . \\
\hline Quercus................ I34 & Salmon-berry ........... I54 \\
\hline Ragweed Family.......... 200 & Salsify ............... 198 \\
\hline Ragworts............. 212 & Salsola............... I 39 \\
\hline 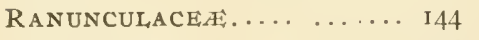 & Salvia ............... Isg \\
\hline aculus $\ldots \ldots \ldots \ldots \ldots$ 146 & Sambucus ............. I95 \\
\hline atibida.............. 208 & Sand Cherry ........... I57 \\
\hline attle-box............. I 59 & Sand Burr ............ I \\
\hline attlesnake Plantair........ I3I & Sandwort.............. I 43 \\
\hline ttlesnake Root......... I99 & Sanguinaria ............ I47 \\
\hline Rayless Goldenrod........ 202 & Sanicula............. I 77 \\
\hline ed Ash.............. I $S_{\mathbf{I}}$ & SANTALACEA $\ldots \ldots \ldots \ldots \ldots$ I 35 \\
\hline Redbud ............. I5s & Saponaria .............. I4 I \\
\hline ed Cedar.............. I06 & Sarsaparilla ........... I 77 \\
\hline Red Osier............... I 79 & Savastana.............. I II \\
\hline Red Raspberry... ........ I54 & Saxifraga. ............ 152 \\
\hline edrost .............. I70 & SAXIFRAGACEA $\ldots \ldots \ldots \ldots$ I 52 \\
\hline Redtop ................ II 3 & Saxifrages.............. ${ }_{152}$ \\
\hline
\end{tabular}


Schedonnardus ........... II 5

SCHEUCHZERIACE

Schollera............... 126

Schrankia.............. I58

Schrophularia ........... I9I

SCHROPHULARIACE, . ....... 19I

Scirpus.............. 121

Scouring-rush ........... 105

Scutellaria ............. IS8

Sedges............... 120

Sedum ............... I52

Selaginella ............. I05

SELAGINELL, ACE E........ I05

Selfheal ............... Isg

Senaca Grass............. III

Senecio................. 2II

Senna Family............ I5S

Sensitive-brier ............ ${ }_{15}$

Sensitive fern............ 103

Senitive Pea............ I5S

Service Berry........... 157

Setaria............... 110

Sheep Sorrel ............ 136

Shepherdia ............. I74

Shepherd's Purse.......... I50

Shin-leaf ............... ISo

Shoe-string............ I6I

Shooting $\operatorname{Star...........~IS~I~}$

Sickle-pod............ I5 I

Sicyos............... 197

Silene............... I4 I

Silphium............. 207

Silver-berry ............ I 74

Silver Maple............. I69

Sinapsis.............. I $4 \mathrm{~S}$

Sisymbrium ........... I 48

Sisyrinchium ........... I30

Sium............... I 78

Skullcap ............... I 8 S

Skunk-bush ............ 169

Slippery Elm........... I 34

Smartweed ........... . I 37

SMILACACEA........... I 29

Smilacina ............. I 28

Smilax............... 129

Snakeroot............. I 77

Sneezewort ............. 2 I0
PAGE

Snowberry ................ I96

Soapwort.............. I4 I

Sof Maple............. 169

SolanaCE $2 . . . \ldots \ldots \ldots \ldots$. I90

Solanum .............. 191

Solidago............... 202

Solomon's Seal ............ I 29

Sonchus ............... I98

Sophia ............... 150

Sophora................ I 5 S

Sorbus ................. 156

Sow Thistle............ 198

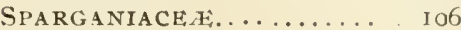

Sparganium ............ 106

Spartina.............. I15

Spear.grass ............. 117

Specularia.............. 197

Speedwells .............. I93

Spergula .............. 143

SPERMOPHYTI: ; ....... Y 45

Spiderwort $\ldots \ldots \ldots \ldots \ldots . \quad 126$

Spiesia................ 163

Spikenard ............. I 28

Spike-rushes ........... I 20

Spiræa................ 154

Spiranthes............. I3 I

Spirocela............... 126

Spleenwort............ 104

Sporobolus ............ 112

Spruce ............... 105

Spurey............... I47

Spurge Family........... 163

Spurges ............... 167

Squaw Currant............ 153

Squirrel-tail-grass.......... 119

Stachys ............... ISg

Staff-tree Family......... I69

Staghorn Sumac.......... I 69

Stanleya .............. I 4 S

Star-grass. . . . . . . . . . I 30

Steironema............ IS I

Stellaria ............... I4 2

Stickseeds............. 1 S6

Sticktight ........... 2c9

Stipa............... II I

Stitch-wort ............ I 42

St. Johns-wort Family... ... 17 I 
Stock ............. I I I

Stonecrop .............. 152

Strawberry .............. 154

Streptopus ............... 129

Strong-scented Eragrostis.... 116

Strophostyles............ I $6_{5}$

Sugar Maple........... . . . . 169

Sumac Family............ 169

Sunflower .............. 208

Sweet Cicely............ r 78

Sweet Clover............. I 59

Sweet Coltsfoot..........2 2 II

Sweet Flag.............. 125

Sweet Locust............. I58

Swertia................ $\mathrm{S}_{2}$

Symphoricarpus ........... I96

Syutherisma.............. I 109

Synthris.............. I92

Talinum............... I4 I

Tall Marsh-grass........... . I 5

Tanacetum .............. 210

Tansy ................. 210

Tausey Mustard......... 150

Tape-grass .............. Ios

Taraxacum ............. igs

Tare ................. 165

Tellima ................ 153

Teucrium ............... IS

Texas Thistle .......... 191

Thalaspi................. I 48

Thalesia.................. I94

Thalictrum ............. 147

Thermopsis............... I59

Thin-grass............... I I 3

Thistle Family........... 200

Thistles .............. 212

Thorn-apple............ I 57

Thoroughwort ..........201

Tickseed .............. 109

Tick-trefoils ............. . I 64

Timothy .............. I 12

Tilia ............... I 7 I

TILIACEA ............. I7 I

Toad Flax............. 191

Toad Rush ............. 126

Tobacco Root............. 196

Touch-me-nots........... I70
PAGE

Tower Mustard............ I5 I

Tradescantia ............. 126

Tragopogon .............. Igs

Trailing Mabonia ........... 147

Trifolium................ I 59

Triglochiu............... Ios

Trillium ................. 129

7 roximon................ 198

Tumble Weerl.............. I4

Tumbling Mustard......... I4S

Turkey-foot Grass ......... I09

Twinflower ............... 195

Twist-foot .............. 129

Typha.................. I06

Typhace .............. 106

ULMACE $A_{1} \ldots \ldots \ldots \ldots \ldots . . .$. I 34

Ulmus ................... . I 34

Umbrella-wort . . . . . . . . . . I I

UMBELLIFER $A$. . . . . . . . I 177

Umbelworts ............. I 77

Unifolium . . . . . . . . . . . . . . I 29

Urtica ................. 135

UR'TICACE $A: \ldots \ldots \ldots \ldots \ldots \ldots$ I 35

Urticastrum ............ 135

Utricularia ............... 194

Uvularia............... . I 27

Vaccaria................ 14I

VACCINEACEA: ........... I 80

Vaccinium ............. 180

Vagnera................. I2 8

Valerian ................ I97

Valeriana ................ 196

VALERINACE $1: \ldots \ldots \ldots \ldots \ldots$. . . . 96

Vallisneria............... I08

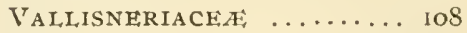

Venice Mallow........... I7I

Venus-hair fer1............. I04

Verbascum .............. I9I

Verbena................ I 87

VERBENACE $A$. ........... I 87

Vernonia.............. 200

Veronica................. 192

Vervain Family.......... . . I $\mathrm{S}_{7}$

Vervains ................ 187

I'esicaria................ I50

Vetch.................. 164

Vetchlings .............. I65 
Viburnum.............. 195

Vicia................. 164

Viper's Bugloss........... I $S_{7}$

Viola.................. I 72

VIOLACE, . . . . . . . . 172

Voilet Family........... I 72

Virginia creeper........... I70

Virginian Grape-fern......... I03

Virgin's Bower........... 145

Viscid Aster ............. 205

VITACEA $\ldots \ldots \ldots \ldots \ldots \ldots .170$

Vitis................. I 70

Wahoo................ 169

Wake-robin . ........... 129

Wall-flower............ ${ }_{52}$

Walnut.............. I3 I

IVashingtonia........... I 78

Water-cress.............. I49

Water-crowfoot.......... I 46

Water Fennel............. 168

Water Helmock.......... I79

Water Hemp............. I40

Water Hoarhound........ I90

Waterleaf Family.......... I $S_{5}$

Water Lilies............. I43

Water Millfoil Family....... I 76

Water-Plantain .......... ros

Water Starwort Family..... 268

Water Star-grass........... 126

Waterwort ............. I72

Water-whirl Grass.......... I I6

Western Blight .......... 139

Western Ruppia........... 107

Western Stipa........... I I I

Western Water Hemp...... I 40

Western Wheat Grass....... I I9

Western Yellow Pine....... I05

Wheat-grass............. I 8

White Ash............ I $\mathrm{SI}$

White Campion........... I4 I

Whita Clover............ 159

White Daisy............ 210
$I A G E$

White Elm............ I 34

White Grass.............. I 10

White Mustard........... I 4 S

White Sage............. I 39

White Spruce............ I05

Whitlow-grass........... 150

Will Bean............. $16_{5}$

Wild Bergamot........... Is9

Wild Carrot............ I77

Wild Leeks.............. I 27

Wild Licorice............ I64

Wild Oats.............. II

Wild Cnions............ I 27

Wild Parsnip............ 177

Wild Peas.............. 165

Wild Plum............. I57

Wild Rice.............. I Io

Wild Rye.............. I I9

Wild Sarsaparilla......... 177

Willow Herb............ 174

Willows .............. I32

Wind Flower............. 145

Wintergreen Family........ I 80

witch Grass.............. I 10

Wolfberry.............. I96

Wolfsbane.............. I44

Woodbine ............ I70

Wood Nettle............. I 35

Woodsia................ I03

Wood-sorrel Family......... I66

Wormwood.............. 2 Io

Wultenia.............. 193

Xanthium.............200

Xanthoxylum ........... 167

Yarrow.................. 210

Yellow Pine............ 105

Yucca............... $12 S$

ZANNICHELLIA . ......... 107

Zizania................ 110

Zizia............... I $7 \mathrm{~S}$

Zygademus............ 127 
$$
\text { - }
$$ 


\section{ERRATA.}

Page I0I, 7 th line, for herberium, read herbarium.

Page 103, 5th line, for matricarifolium, read matricariaefolium.

Page 106, 4 th line, insert (L) after Virginiana.

Page 107 , 3oth liue, for occidentalis, read occidentalis.

Page 110,8 th line, for Capillare, read capillare.

Page $110,14^{\text {th }}$ and $15^{\text {th }}$ lines, for Viridis and Viridis, read viridis and viridis.

Page 111 , 2oth line, for Spartea, read spartea.

Page 112, 14th line, for Sylvatica, read sylvatica.

Page 114,5 th line, for macouniana, read Macouniana.

Page 114,39 th line, for Striata, read striata.

Page Ir5, ist line, for Danthona, read Dauthonia.

Page 115, 3rd line, for Cynosuroides, read cynosuroides.

Page 115 , igth line, for Curtipendula, read curtipendula.

Page 116 , 4th line, for purshii, read Purshii.

Page 116,6 th line, for Major, read major.

Page 118 , 24th line, Cough-grass, read Couch-grass.

Page 119, 15th line, for Jubatum, read jubatum.

Page IIg, zoth liue, for Elymoides, read elymoides.

Page 126, 2nd line, for Spirodella, read Spirodela.

Page 126 , Ith line, for virginiana, read Virginiana.

Page 128,27 th line, for Officinalis, read officinalis.

Page 128 , 3oth line, for Spiknard, read Spikenard.

Page 129 , 6th line, for amqlexicaulis, read amplexicaulis.

Page 129, 22nd line, for Commutatum, read commutatum.

Page 130, I2th line, for augustifolium, read angustifolium.

Page 130,27 th, 31st, 34th lines, for Cyprepedinm, read Cypripedium.

Page 133 , 17 th line, for virginica, read Virginica.

Page 139. 7 th and 8th lines, for Cycloma, read Cycloloma.

Page 14I, 16th line, for Silena, read Silene.

Page $14 \mathrm{I}$, Igth and 21 st lines, Lychinis, read L,ychnis.

Page 141, Igth line, for Champion, read Campion.

Page 142,12 th, 14 th, 17 th and 20 th lines, for Silena, read Silene.

Page 142 , I2th, 14th and ifth lines, for Champion, read Campion.

Page 143, 24th line, for oderata, read odorata.

Page 144, 28th line, for Fisher's, read Fischer's.

Page 145,5 th line, for virginiana, read Virginiana.

Page 150, 15th line, for Shepard's, read Sheperd's.

Page 153, 12th line, for Setosum, read setosum.

Page 153, 15th line, for Riber, read Ribes.

Page 154, I2th line, for nutkanus, read Nutkanus.

Page 154, 31st line, for Vesca, read vesca.

Page 155, 15th line, for hippiana, read Hippiana.

Page 155 , 2oth line, for fruiticosa, read fruticosa.

Page 156, gth line, for Macrophyllum, read macrophyllum.

Page 156, 17 th line, for Agrimonia, read Agromonia.

Page 156, 2oth line, for Agrimonia, read Agromonia.

Page 156 , 28th line, for woodesii, read Woodsii.

Page 161, 17th, 21st, 26th and 3rst lines, for Pelalslemon, read Petalosiemon.

Page 165, 21st and 22nd lines, for A pois, read Apios.

Page 168 , 19th line, for dictyosporma, read dictyosperma. 
Page 168 , 25th line, for mountain, read montana.

Page 169 , 16th line, for atropurpureous, read atropurpureus.

Page 170,27 th line, for Vulpina, read vulpina.

Page 17r, 4th line, for 'rilliacere, read 'Tiliacere.

Page $17 \AA$, loth line, for Sylvestris, read sylvestris.

Page 177,5 th line, for carrota, read carota.

Page 178,1 st line, for canadensis, read Canadensis.

Page 178, and line, for canadensis, read Canadensis.

Page 179 , I3th line, for canadensis, read Canadensis.

Page 179, I8th line, for augustifolia, read angustifolia.

Page 150,8 th line, for Elliptica, read elliptica.

Page 184,2 oth line, for Epithymum, read epithymum.

Page 185,29 th line, for Curassavicum, read curassavicum.

Page 187, 24th line, for Molle, read molle, for Cromwell, Gromwell

Page 189,28 th and 30 th lines, for Bergamont, read Bergamot.

Page 203,25 th line, for Radula, read radula.

Page 209, 17th line, Cereopsis, read Coreopsis. 


New York Botanical Garden Library

QK 172.528

gen

Saunders, De Alton/Ferns and flowering $p$

|| || ||| ||| || || ||||||||||||||||||||||||||||||||||||

35185000301182

35185000301182 
